\title{
Development and Characterization of Basalt Glass Ceramics for the Immobilization of Transuranic Wastes
}

\author{
R. O. Lokken \\ L. A. Chick \\ L. E. Thomas
}

September 1982

Prepared for the U.S. Department of Energy under Contract DE-AC06-76RLO 1830

Pacific Northwest Laboratory

Operated for the U.S. Department of Energy

by Battelle Memorial Institute 


\title{
DISCLAIMER
}

This report was prepared as an account of work sponsored by an agency of the United States Government. Neither the United States Government nor any agency thereof, nor any of their employees, makes any warranty, express or implied. or assumes any legal liability or responsibility for the accuracy, completeness, or usefulness of any information, apparatus, product, or process disclosed, or represents that its use would not infringe privately owned rights. Reference herein to any specific commercial product, process, or service by trade name, trademark, manufacturer, or otherwise, does not necessarily constitute or imply its endorsement, recommeridation, or favoring by the United States Government or any agency thereof. The views and opinions of authors expressed herein do not necessarily state $\mathrm{cr}$ reflect those of the United States Government or any agency thereof.

\author{
PACIFIC NORTHWEST I.ABORATORY \\ operated by \\ BATTELLE \\ for the \\ UNITED STATES DEPARTMENT OF ENERGY \\ under Contract DE-AC06-76RLO 1830
}

\begin{tabular}{|c|c|}
\hline \multicolumn{2}{|c|}{$\begin{array}{l}\text { Printed in the United States of America } \\
\text { Available from } \\
\text { National Technical Information Service } \\
\text { United States Department of Commerce } \\
5285 \text { Port Roval Road } \\
\text { Springfield. Virginia } 22151\end{array}$} \\
\hline \multicolumn{2}{|c|}{$\begin{array}{l}\text { NTIS Price Codes } \\
\text { Microfiche A01 }\end{array}$} \\
\hline \multicolumn{2}{|c|}{ Printed Copy } \\
\hline Pages & $\begin{array}{l}\text { Price } \\
\text { Codes }\end{array}$ \\
\hline $001-025$ & $\mathrm{~A} 02$ \\
\hline $026-050$ & $\mathrm{~A} 03$ \\
\hline $051-075$ & A04 \\
\hline 076-100 & A05 \\
\hline $10:-125$ & A06 \\
\hline $126-150$ & $\mathrm{~A} 07$ \\
\hline $151-175$ & $\mathrm{~A} 0 \mathrm{~B}$ \\
\hline $176-200$ & $A 09$ \\
\hline $201-225$ & $A 010$ \\
\hline $226-250$ & A011 \\
\hline $251-275$ & $\mathrm{~A} 012$ \\
\hline $276-300$ & A013 \\
\hline
\end{tabular}


DEVELOPMENT AND CHARACTER IZATION OF BASALT GLASS CERAMICS FOR THE IMMOBILIZATION OF TRANSURANIC WASTES

R. 0. Lokken

L. A. Chick

L. E. Thomas (a)

September 1982

Prepared for the U.S. Department of Energy under Contract DE-ACO6-76RLO 1830

Pacific Northwest Laboratory Richland, Washington 99352

(a) Hanford Engineering Development Laboratory, Rich 1and, Washington. 


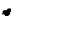

. 
SUMMARY AND CONCLUSIONS

Basalt-based waste forms were developed for the immobilization of transuranic (TRU) contaminated wastes. The specific waste studied is a $3: 1$ blend of process sludge and incinerator ash typical in composition to the waste produced at the Rocky Flats Plant in Colorado. The major constituents of the waste are the same as in basalt, making the waste amenable to vitrification with basalt. This report describes development activities associated with the immobilization of TRU blended waste in basalt-based forms, both vitreous and semi-crystalline (glass ceramics).

Various amounts of TRU blended waste of reference composition (TBW-R) were melted with Pomona basalt powder. The vitreous products were subjected to a variety of heat treatment conditions to form glass ceramics. The total crystallinity of the glass ceramic, ranging from 20 to $45 w t \%$, was moderately dependent on composition and heat treatment conditions.

Three parent glasses and four glass ceramics with varied composition and heat treatment were produced for detailed phase characterization and leaching. The parent basalt glasses were found to be phase separated with most of the Fe and $\mathrm{Ti}$ concentrated in the dispersed phase. The glass ceramics contained three major phases: a titaniferous hematite (mainly $\mathrm{Fe}$ and $\mathrm{Ti}$ ), a $\mathrm{clinopyroxene}$ (mainly $\mathrm{Fe}, \mathrm{Si}, \mathrm{Ti}$, and $\mathrm{Al}$ ), and augite ( $\mathrm{Si}, \mathrm{Ca}, \mathrm{Mg}$, and $\mathrm{Fe}$ ).

Both parent glasses and glass ceramics were mainly composed of a continuous, glassy matrix phase. This glass matrix entered into solution during leaching in both types of materials. The Fe-Ti rich dispersed glass phase in the parent glasses and the crystals in the glass ceramics were not significantly degraded by leaching. The glass ceramics, however, exhibited four to ten times less elemental releases during leaching than the parent glasses. The leach rate difference is believed due to composition differences between the continuous glass matrix phases. The glass ceramic matrix probably contains higher $\mathrm{Fe}$ and $\mathrm{Na}$ and lower $\mathrm{Ca}$ and $\mathrm{Mg}$ relative to the parent glass matrix. The 
crystallization of augite in the glass ceramics, which removes $-50 \%$ of the $\mathrm{Ca}$ and $\mathrm{Mg}$ from the glass matrix, is believed to contribute to the improved leach rates.

Leach rates of the basalt glass ceramic are compared to those of other TRU nuclear waste forms containing ${ }^{239} \mathrm{pu}$. The glass ceramic is found to have the lowest dissolution rates for the matrix elements, but a relatively higher leach rate for $\mathrm{Pu}$. The higher Pu release probably results from the dependence of $\mathrm{Pu}$ solubility on $\mathrm{pH}$. Faster matrix element release by the other waste forms results in more alkaline solution $\mathrm{pH}$ which in turn represses the Pu solubility. 


\section{CONTENTS}

SUMMARY AND CONCLUSIONS

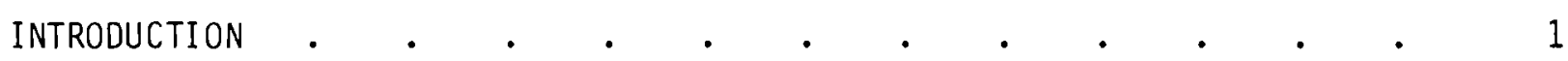

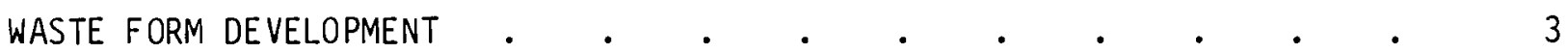

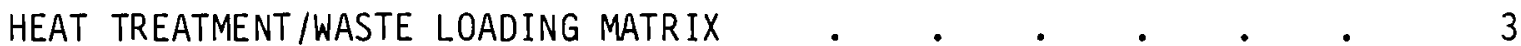

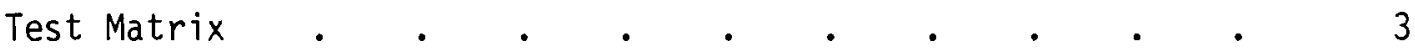

Estimated Total Crystallinity by X-Ray Diffraction . . 3

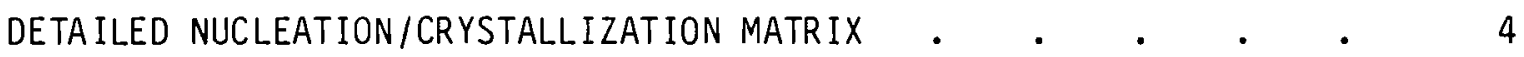

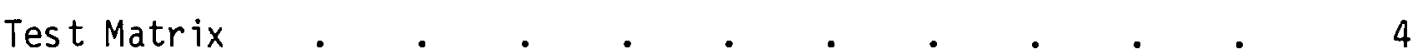

Bulk Densities by Immersion . . . . . . . 5

SEM Examination of Fracture Structures . . . . . 5

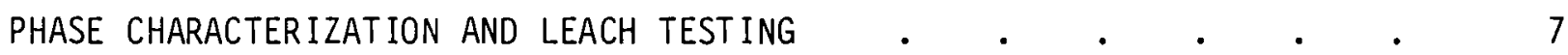

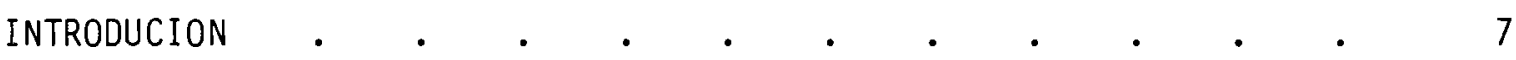

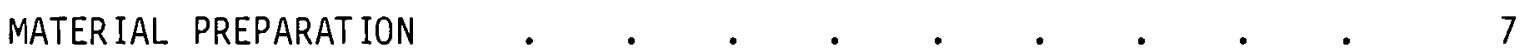

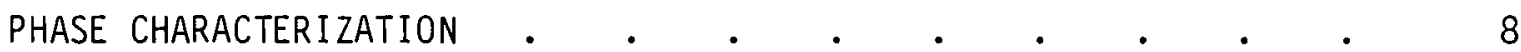

Parent Glass Characterization by Optical Microscopy $\quad$. 8

Glass Ceramic Characterization by SEM, STEM, and XRD . $\quad 8$

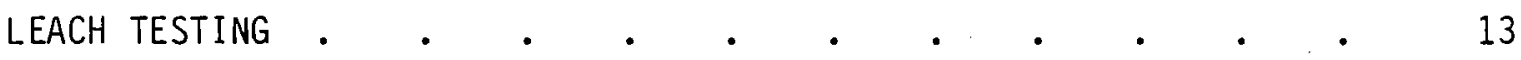

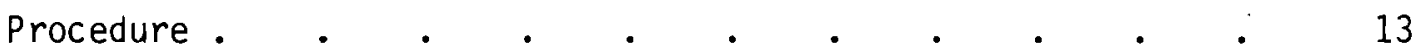

Elemental Release Results $\quad . \quad$. $\quad . \quad$. $\quad . \quad . \quad . \quad 14$

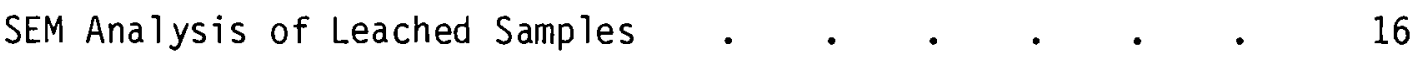

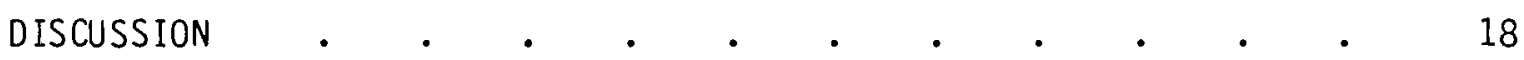

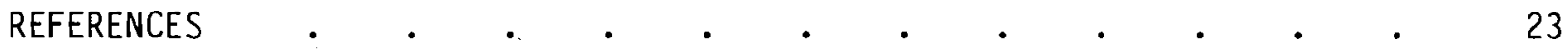

APPENDIX - SAMPLE PREPARATION AND CHARACTERIZATION PROCEDURES • • A.1 
1 SEM Fractographs Showing Effect of Nucleation Time on Microstructure of Basalt Glass Containing $50 \mathrm{wt} \%$ TBW-R . . . . . . 41

2 SEM Fractographs Showing Effect of Nucleation Temperature on Microstructure of Basalt Glass Containing 50 wt\% TBW-R . . . 42

3 SEM Fractographs Showing Effect of Cyrstallization Time on Microstructure of Basalt Glass Containing 50 wt\% TBiw-R.

4 SEM Fractographs Showing Effect of Nucleation Temperature on Microstructure of Basalt Glass Crystallized for $8 \mathrm{n}$ at $950^{\circ} \mathrm{C}$. $\quad 44$

5 SEM Fractographs Showing Effect of Crystallization Temperature on Microstructure of Basalt Glass Nucleated $2 \mathrm{~h}$ at $700^{\circ} \mathrm{C}$. $\quad 45$

6 Optical Micrograph of Parent Glass SBG-63 . $\quad$. $\quad . \quad$. $\quad$ • 46

7 Optical Micrograph of Parent Glass BG-35 . . . . . . . . . 46

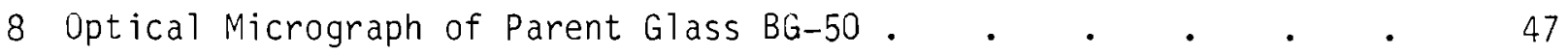

9 Polished Surface Scanning Electron Micrograph of Glass Ceramic BGC-35-1

10 Polished Surface Scanning Electron Micrograph of Glass Ceramic BGC-35-2

11 Polished Surface Scanning Electron Micrograph of Glass Ceramic BGC-50.

12 Polished Surface Scanning Electron Micrograph of

13 Darkfield TEM Micrograph of Glass Ceramic BGC-35-1 . . . . 50

14 Darkfield TEM Micrograph of Glass Ceramic BGC-35-2 . • . . . 50

15 Brightfield TEM Micrograph of G1 ass Ceramic SBGC-63 $\quad$ • $\quad$ • 51

16 Brightfield and Darkfield TEM Micrographs of Glass Ceramic BGC-50

17 Powder X-Ray Diffraction Pattern for BGC-35-1 and BGC-35-2 • . 52

18 Powder X-Ray Diffraction Pattern for BGC-50 and SBGC-63 . • . 53

19 Solution $\mathrm{pH}$ for Static MCC-1 Leach Test . . . . . . . 54 


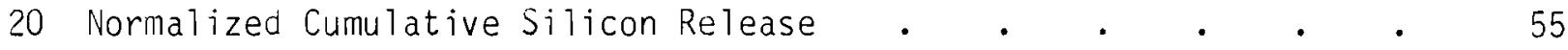

21 Normalized Cumulative Aluminum Release . . . . . . . . 56

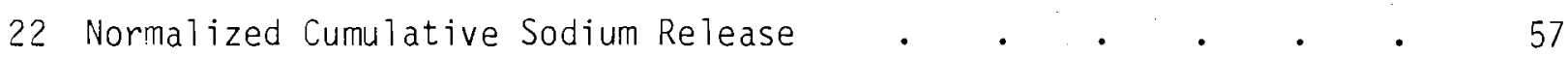

23 Normalized Cumulative Calcium Release $\quad$. $\quad$. $\quad$. 58

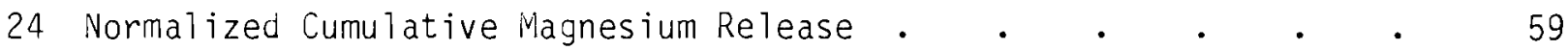

25 Scanning Electron Micrographs of Parent G1ass BG-50 After

26 Energy Dispersive X-Ray Spectra of Leached Parent Glass BG-50 • 61

27 Scanning Electron Micrographs of G1ass Ceramic BGC-50 After

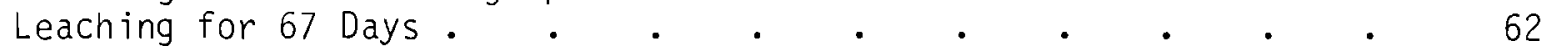

28 Scanning Electron Wicrographs of Glass Ceramic BGC-35-2 After

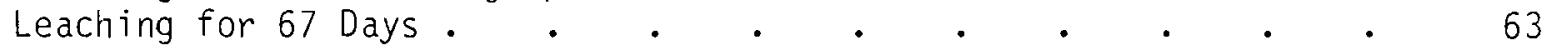

29 Scanning Electron Micrographs of Surfaces Before and After

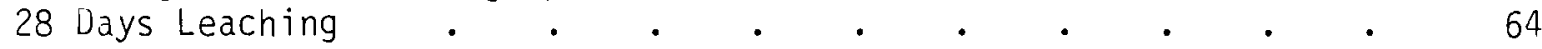

30 Scanning Electron Micrograpns of 28-Day Leached Surfaces • • • 65

31 Energy Uispersive X-Ray Spectra from $300 \times 300 \mu \mathrm{m}$ Areas on Sample Surfaces Before and After 28-Day Leaching . . . . . 66

32 Scanning Electron Micrographs of Precipitate on Leached Surface

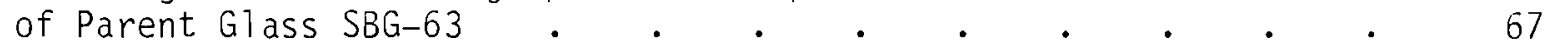

33 Energy Dispersive $X$-Ray Spectra on Surface of Parent Glass SBG-63 . . . . . . . . . . . . . . . . . .

A.1 Ultrathin Window EDAX Spectra From Phases in Glass Ceramic $\mathrm{BGC}-35-2$ 


\section{TABLES}

1 Chemical Compositions of Typical Sludge, Ash, Waste Blend,

2 Heat Treatment Matrix

3 Total Crystallinity of Basalt Glass Ceramics After Various

Heat Treatments.

4 Nucleation/Crystallization Conditions Applied to Basalt Glass with 50 wt\% TBW-R . $. \quad . \quad . \quad . \quad . \quad . \quad . \quad 28$

5 0xide Compositions of TBW-R, Pomona Basalt, and Synthetic Basalt Additives . . . . . . . . . . . 29

6 Compositions of Parent Glasses Determined by KUH Fusion/ICP . . 30

7 Waste Forms Produced for Phase Characterization and Leach Testing . 31

8 Crystal Morphologies Observed in Glass-Ceramics . . . . 32

9 Glass-Ceramic Phase Compositions Determined by STEM . . . 33

10 Identification of Pyroxene Crystals in BGC-50 by Selected Area Diffraction Ring Patterns. . . . . . . . . 36

11 Residual Glass Phase Compositions . . . . . . . . 37

12 Crystalline Phase Yield in Glass Ceramics Determined by XRD . . . . . . . . . . . . 37

13 Normalized Elemental Mass Losses for Static MCC-1 Leach Test, $90^{\circ} \mathrm{C}$, D.I. Water, $\mathrm{SA} / \mathrm{V}=10 \mathrm{~m}^{-1}$. . . . . . . 38

14 Estimates of Glass Matrix Composition . . . . . . 40

15 Comparison of Leachability of Basalt Giass Ceramic with Other TRU Nuclear Waste Forms Containing 239 Pu. . . . . . 40

A.1 Comparison of Bulk (ICP) Analyses with EDX Microanalyses of $5 \mu \mathrm{m}$ Square Thin Specimen Regions of BGC-50 . . . . . . . A.6 


\section{INTRODUCTION}

Radioactive waste contaminated with transuranium (TRU) elements, produced by a variety of government research and defense programs, may pose long-range environmental hazards if not adequately immobilized in forms able to meet or surpass disposal criteria currently being developed. TRU wastes, for the purpose of this study, are defined as wastes containing greater than $10 \mathrm{nCi}$ of certain long-lived alpha-emitting radionuclides per gram of waste (Bryan 1981). As an integral part of the TRU Waste Immobilization Program at Battelle's Pacific Northwest Laboratory (PNL) numerous waste immobilization techniques have been applied to a selected TRU waste stream consisting of a blend of process sludge and incinerator ash (Timmerman 1980). The composition of the waste is shown in Table 1.

One possible site for the final disposal of immobilized TRU wastes is on federal land at the Hanford reservation in Washington State. There, the wastes might be emplaced in a deep, geological repository in basalt formations (Ames 1980). It has been suggested (Donath 1978) that there may be some advantage to designing waste immobilization forms with similar chemistry to the rocks in which they are to be stored. The waste forms would then be more compatible with the geology. That is, interactions between the waste form and the surrounding rocks might be less likely to result in dissolution and transport of radionuclides. Although this idea has yet to be tested, it is intuitively attractive. Since the composition of the TRU waste blend is similar to that of basalt (see Table 1) it seemed logical to develop basalt-based TRU waste forms.

Beall and Rittler (1976) were the first investigators to make basalt glass ceramics. They melted natural basalt to produce a black, vitreous product, which, upon reheating, recrystallized into a fine grained, chemically resistant glass ceramic. Based on their work, Lokken (1981) developed basalt-based waste forms for the immobilization of high-level nuclear waste calcines. These also demonstrated excellent chemical durabilities, and led to further development and characterization directed toward TRU wastes reported here. 
More recently, a new approach to radioactive waste immobilization has been investigated. This technique, called in situ vitrification, is the in-place melting of buried waste and the surrounding soil (Brouns and Timmerman 1982). Upon cooling, the vitrified soil crystallizes, producing phases similar to those formed in basalt glass ceramics.

The first section of this report describes development studies designed to investigate the effects of waste loading and heat treatment on the crystallinity of the glass ceramics. On the basis of these development studies, three parent glasses and four glass ceramics were chosen for more detailed study. The second part of the report describes the phase characterization and leach testing of these seven materials. 


\section{WASTE FORM DEVELOPIMENT}

The first phase of development of basalt-based TRU waste forms consisted simply of mixing various amounts of simulated TRU blended waste vitn Pomona basalt and heating to various temperatures. The mixtures, ranging from 20 to $100 \mathrm{wt} \%$ TRU blended waste (TBW-R), were heated in air to temperatures up to $1400^{\circ} \mathrm{C}$ in platinum crucibles. The powdered mixtures began fusing together at temperatures from 1100 to $1150^{\circ} \mathrm{C}$ with those containing the higher percentages of TBW-R demonstrating the highest degree of fusion. Temperatures of 1250 to $1350^{\circ} \mathrm{C}$ were necessary to assure homogeneity (after $2 \mathrm{hr}$ ) and to allow sufficiently low viscosity to pour $\sim 100 \mathrm{~g}$ of glass. A vitreous condition of all materials was confirmed by $x$-ray diffraction analysis.

\section{HEAT TREATMENT / WASTE LOADING MATRIX}

Test Matrix

Four materials were prepared for determining the effect of differing heat treatments on crystalline phase yield and physical properties. The materials included basalt glass with 20,35 , and $50 \mathrm{wt} \%$ TBW-R and one glass of $100 \%$ TBW-R. A11 were melted at $1300^{\circ} \mathrm{C}$ for $2 \mathrm{~h}$ and air quenched by pouring onto a cold steel plate. Samples were heat treated according to the conditions noted in Table 2. The heat treatment conditions were based on previous work of Lokken (1981). The nucleation treatment ranged from 700 to $800^{\circ} \mathrm{C}$ for from $1 / 2$ to $6 \mathrm{~h}$ and the crystal growth treatment ranged from 950 to $1050^{\circ} \mathrm{C}$ for from 1 to $8 \mathrm{~h}$. The samples were characterized by powder $x$-ray diffraction.

Estimated Total Crystallinity by X-Ray Diffraction

Total crystallinity produced by the heat treatment was estimated using a semi-quantitative $x$-ray diffraction (XRD) technique. Powder diffraction patterns from each material were analyzed by computer to determine total integrated peak areas. Total crystallinity figures were estimated by comparison with the total integrated peak area produced by a mixture of 20 wt\% trevorite $\left(\mathrm{NiFe}_{2} \mathrm{O}_{4}\right)$ with 80 wt\% vitreous waste glass filler. Although the actual quantities listed in Table 3 are probably accurate to no more than \pm 10 wt\%, 
they are reported to $\pm 1 \mathrm{wt} \%$ because the similarities of the crystal phase mixtures produced in all samples probably allows \pm 1 wt\% internal comparison of the data to determine the relative effects of heat treatment and composition. The values in the table are grouped according to heat treatment to illustrate crystallinity differences with only one variable. The first group of data illustrates the effect of crystallization time at $950^{\circ} \mathrm{C}$ following nucleation at $700^{\circ} \mathrm{C}$ for $1 / 2 \mathrm{~h}$. In all samples the amount of crystallinity increased with time from 1 to $4 \mathrm{~h}$. However, two basalt glass ceramics (BG-20 and BG-35) demonstrated decreases in total crystallinity from 4 to $8 \mathrm{~h}$. The second group illustrates the effect of nucleation time on crystallinity. There appears to be no significant effect of nucleation time on the total crystallinity of basalt glass with $35 \mathrm{wt} \%(B G-35)$ or $50 \mathrm{wt} \%$ TBW-R (BG-50), while the crystallinity of $100 \%$ TBW-R (TBW-R-G) decreased from 34 to $27 \mathrm{wt} \%$ between 2 and $6 \mathrm{~h}$ of nucleation time. Increasing the nucleation temperature had a minimal effect on total crystallinity as evidenced by the third group of data. The fourth group shows the effect of increasing crystal growth temperature on total crystallinity. The crystallinity of $B G-20$ increased from $24 \mathrm{wt} \%$ after $1 \mathrm{~h}$ at $950^{\circ} \mathrm{C}$ to $33 \%$ after $1 \mathrm{~h}$ at $1050^{\circ} \mathrm{C}$. Similar increases were seen for BG-35 and BG-50; the increase for 100\% TBW-R was much smaller (from 25 to $29 \%$ ). Comparison of group 4 with group 5 data shows that after crystallizing for 7 additional hours at 950,1000 , and $1050^{\circ} \mathrm{C}$, the total crystallinity of all samples increased. At the $8 \mathrm{~h}$ crystallization time the crystallinity of the 20,35 , and $50 \mathrm{wt} \%$ waste loaded materials tended to increase with increased temperature. However, for the TBW-R-G material, the crystallinity decreased with increasing temperature.

\section{DETAILED NUCLEATION/CRYSTALLI ZATION MATRIX}

Test Matrix

In an effort to understand the structural changes associated with different heat-treatment conditions, a series of heat treatments were applied to samples of basalt glass containing 50 wt\% TBW-R (BG-50-R2). The samples were cut from glass bars that had been melted at $1300^{\circ} \mathrm{C}$ and annealed at $550^{\circ} \mathrm{C}$ for $2 \mathrm{~h}$. The heat-treatment conditions applied to the samples are listed in 
Table 4. Nucleation temperatures ranged from $675^{\circ} \mathrm{C}$ to $850^{\circ} \mathrm{C}$ and crystallization temperatures ranged from $850^{\circ} \mathrm{C}$ to $1100^{\circ} \mathrm{C}$. The samples heat treated at $1100^{\circ} \mathrm{C}$ exhibited gross deformation because the melting temperature of some of the crystal phases was exceeded.

Bulk Densities by Immersion

The densities of the samples were measured by an immersion technique using isopropyl alcohol as the immersion medium. The measurements indicate the range of density change is quite small with the majority of change occurring between $550^{\circ} \mathrm{C}$ (annealing temperature) and $\sim 725^{\circ} \mathrm{C}$. Fully annealed glass had a density of $2.80 \mathrm{~g} / \mathrm{cm}^{2}$, while subsequent heat treatments at $675^{\circ} \mathrm{C}, 700^{\circ} \mathrm{C}$, and $725^{\circ} \mathrm{C}$ yielded densities of $2.83,2.85$, and $2.94 \mathrm{~g} / \mathrm{cm}^{3}$, respectively. At temperatures above $725^{\circ} \mathrm{C}$ the densities were nearly equal at $\sim 2.92 \mathrm{~g} / \mathrm{cm}^{2}$. Heating the samples for various times at $700^{\circ} \mathrm{C}$ also resulted in increased density, increasing from 2.82 to $2.89 \mathrm{~g} / \mathrm{cm}^{3}$ after 0.5 and $6 \mathrm{~h}$, respectively.

SEM Examination of Fracture Surfaces

Sixteen of the samples listed in Table 4 were fractured and examined using scanning electron mircoscopy to observe the effect of heat-treatment conditions in fracture-surface morphology. The samples were fractured by impact, with diamond scratches on the surface serving as stress concentrators.

SEM fractographs of three samples of $B G-50-R 2$ heated at $700^{\circ} \mathrm{C}$ for $0.5,2$, and $6 \mathrm{~h}$ are compared with one of the parent glass annealed for $2 \mathrm{~h}$ at $550^{\circ} \mathrm{C}$ in Figure 1. The annealed parent glass has a smooth surface with what appears to be phase-separated regions. Very little difference is seen between the samples heated for different times at $700^{\circ} \mathrm{C}$. The effect of heating BG-50-R2 for $2 \mathrm{~h}$ at $700^{\circ} \mathrm{C}, 750^{\circ} \mathrm{C}, 800^{\circ} \mathrm{C}$, and $850^{\circ} \mathrm{C}$ on surface morphology is seen in Figure 2. The surface of the sample heated at $750^{\circ} \mathrm{C}$ appears more grainy than the parent glass from the previous figure with evidence of crystallization similar to the phase separation pattern. This pattern is not as noticeable in the sample heated at $800^{\circ} \mathrm{C}$ which appears to be more crystalline. The sample heated at $850^{\circ} \mathrm{C}$ shows no evidence of the phase separation pattern with a uniform, finegrained texture. Figure 3 illustrates the effect of crystallization time on 
the fracture-surface morphology. The samples were heated for $2 \mathrm{~h}$ at $700^{\circ} \mathrm{C}$, followed by crystallization heat treatments at $950^{\circ} \mathrm{C}$ for $1,2,4$, or $8 \mathrm{~h}$. The crystal size (estimated by surface roughness) increases from 1 to $4 \mathrm{~h}$ of treatment with the largest change occurring between 2 and $4 \mathrm{~h}$. There appears to be no significant differences between the surfaces of the samples heated for 4 and $8 \mathrm{~h}$. Increasing nucleation temperatures resulted in smaller apparent crystal size as seen in Figure 4. The samples were nucleated at $700^{\circ} \mathrm{C}, 750^{\circ} \mathrm{C}$, or $800^{\circ} \mathrm{C}$ for $2 \mathrm{~h}$ and crystallized for $8 \mathrm{~h}$ at $950^{\circ} \mathrm{C}$. Figure 5 shows fractographs of four samples crystallized at $900^{\circ} \mathrm{C}, 950^{\circ} \mathrm{C}, 1000^{\circ} \mathrm{C}$, and $1050^{\circ} \mathrm{C}$ for $8 \mathrm{~h}$ after nucleating for $2 \mathrm{~h}$ at $700^{\circ} \mathrm{C}$. The difference in appearance between the samples crystallized at $900^{\circ} \mathrm{C}$ and $950^{\circ} \mathrm{C}$ are quite pronounced with the former having a fine grained, uniform texture, while the latter sample surface shows larger, more irregular fracture characteristics. The surface of the sample crystallized at $1050^{\circ} \mathrm{C}$ shows the largest differences among the samples shown. This sample appears to contain fairly large crystals within a glassy matrix.

Based on these development studies, additional materials were prepared for detailed characterization and leach testing. The selection of conditions was based on total crystallinity, which was relatively independent of waste loading but increased with higher crystallization temperatures. Three parent glasses and four glass ceramics were chosen to determine the effect of waste loading and heat treatment on leach resistance and crystallization. 


\section{PHASE CHARACTERIZATION AND LEACH TESTING}

INTRODUCION

Chemical durability, as determined by leach testing, is the most important property used in evaluating the quality of nuclear waste forms. While numerous other properties must be considered in developing and comparing waste forms, their ability to contain radioactive isotopes in a repository containing ground water is the major concern. Currently, the most well developed and utilized leach test is the Materials Characterization Center (MCC) static test on monolithic samples. MCC-1 (MCC 1981).

Based on the development study described in the first part of this report, four glass ceramic materials were produced from three parent glasses for further characterization and leach testing. Three different waste loadings and two heat treatments were utilized amongst the test materials. These seven materials were characterized in detail and leach tested using the MCC-1 test method.

\section{MATERIAL PREPARATION}

Parent glasses $B G-35, B G-50$, and $S B G-63$ were produced by blending Pomona basalt with 35 and 50 wt\% TBW-R and chemicals with 63 wt\% TBW-R and melting for $2 \mathrm{~h}$ at $1300^{\circ} \mathrm{C}$. Oxide compositions of batch materials used are shown in Table 5. These glasses were cast into bars $19 \mathrm{~mm} \times 19 \mathrm{~mm} \times 80 \mathrm{~mm}$ and annealed for $2 \mathrm{~h}$ at $550^{\circ} \mathrm{C}$. Compositions of the parent glasses, determined by $\mathrm{KOH}$ fusion and inductively coupled plasma atomic emission spectroscopy (ICP), are listed in Table 6. Two glass ceramics were prepared from the BG-35 parent glass by applying two different heat treatment schedules. $B G C-35-1$ was nucleated for $0.5 \mathrm{~h}$ at $700^{\circ} \mathrm{C}$ and crystallized for $4 \mathrm{~h}$ at $950^{\circ} \mathrm{C}$. BGC-35-2 was nucleated for $4 \mathrm{~h}$ at $700^{\circ} \mathrm{C}$ and crystallized for $8 \mathrm{~h}$ at $1050^{\circ} \mathrm{C}$. Two additional glass ceramics, $B G C-50$ and SBGC-63, were produced by heat treating parent glasses BG-50 and SBG-63 with the same schedule used for BGC-35-1. Table 7 summarizes the sample preparation. The bulk compositions of the glass ceramics are assumed to be identical to those of their respective parent glasses listed in Table 6 . 


\section{PHASE CHARACTERIZATION}

The three parent glasses and four glass ceramics listed in Table 7 were characterized by ICP, XRD, SEM, optical microscopy, and scanning transmission electron microscopy (STEM). The parent glasses contain liquid-liquid phase separation with very little crystallinity. The glass ceramics have from about 35 to 45 wt\% total crystallinity distributed among four phases. Since there was extensive overlapping of the XRD peaks for these phases, only semiquantitative analysis of the XRD patterns was possible. The STEM characterization was more successful, producing good estimates of crystal phase and residual glass compositions. Procedures used for XRD, SEM, and STEM sample preparation and characterization are included in the Appendix. Results are presented below. Parent Glass Characterization by Optic al Microscopy

Figure 6 is an optical micrograph of parent glass SBG-63 showing extensive liquid-liquid phase separation with 2 to $5 \mu \mathrm{m}$ diameter dispersed phase droplets (optically dark phase) enriched in $\mathrm{Fe}$ and $\mathrm{Ti}$. The other parent glasses, BG-35 and BG-50 exhibit similar phase separation (Figures 7 and 8 ), except that the dispersed droplets are smaller, about 1.0 to $1.5 \mu \mathrm{m}$ diameter. Figures 7 and 8 show isolated regions in BG-35 and BG-50 with dendritic crystals, indicating some crystallinity is present in the parent glasses. However, XRD traces showed no discernible peaks for the parent glasses indicating that total crystallinity is less than one or two percent. The parent glasses were not analyzed by STEM. SEM and polished sections of the parent glasses showed no discernible features.

Glass Ceramic Characterization by SEM, STEM, and XRD

The SEM micrographs shown in Figures 9 through 12 are representative of the four glass ceramic microstructures. The structures of $B G C-35-1$ (Figure 9) and $B G C-50$ (Figure 11) appear similar, while BGC-35-2 (Figure 10) contains the largest crystals. SBGC-63 (Figure 12) has a fine crystalline microstructure with definite ring structures resulting from the phase separation in the parent glass. 
Six crystal types were identified in the glass ceramics using selectedarea electron diffraction and EDX microanalysis in the analytical TEM/STEM. These are designated by letters $A$ through $F$ on the transmission electron micrographs in Figures 13-16. Their morphologies are described in Table 8.

The microstructure of $B G C-35-1$, shown in Figure 13 , consists of $0.7 \mu \mathrm{m}$ diameter $\times 20 \mu \mathrm{m}$ thick plate-shaped crystals (type $A$ ) surrounded by smaller 0.05 to $0.1 \mu \mathrm{m}$ blocky crystals. The type A crystals were identif ied from single-crystal electron diffraction patterns as ilmenite or hematite. These minerals have similar crystal structures and lattice parameters and form a continuous solid-solution series (Lindsley 1976). Ilmenite $\left(\mathrm{FeTiO}_{3}\right.$ ) and hematite $\left(\mathrm{Fe}_{2} \mathrm{O}_{3}\right)$ have crystal structures which are hexagonal (rhombohedral), with lattice parameters $a_{H}=0.503 \mathrm{~nm}$ (hematite) to $0.509 \mathrm{~nm}$ (ilmenite) and $c_{H}=1.374$ to $1.408 \mathrm{~nm}$ (Lindsley 1976). For positive identification, the diffraction patterns were obtained by tilting individual crystals between several low-index zone axes, and examining interplanar angles as well as systematically absent reflections. Structure factor calculations for the different space groups ( $R 3 C$ and $R 3$ respectively) reported for hematite and ilmenite (Lindsley 1976) showed no differences great enough to distinguish between the two by selected-area diffraction. Based on the lattice parameters measured from type $A$ crystals in $B G C-35-1--a_{h}=0.504 \mathrm{~nm}$; and $c_{h}=1.38 \mathrm{~nm}$, the crystals are nearer the hematite end of the series.

The compositions obtained by EDX microanalysis, listed in Table 9, show that the type A crystals are iron titanates with an Fe to $\mathrm{Ti}$ atom ratio of about three to one. This agrees with the diffraction data, indicating that the type $A$ crystals are intermediate members of the hematite-ilmenite series, near the hematite composition.

The smaller crystals in regions between the type A titaniferous hematites were also identified by selected area electron diffraction as mainly clinopyroxenes similar to augite. The small crystals gave incomplete diffraction rings as shown in an inset pattern in Figure 13. D-spacings measured from the ring patterns are compared with d-spacings for two clinopyroxenes, omphacite 
and fassaite, in Table 10. Between these two minerals the d-spacings given by ASTM cards 17-522 and 25-306A account for almost all of the observed ref lections.

The EDX microanalyses also showed that the small crystals are divided about equally into two distinctive composition ranges. Type $B$ is an iron and sodium-rich silicate with high aluminum and magnesium but low calcium, and type $C$ is a calcium, magnesium, aluminum, iron silicate. Comparison with pyroxene compositions (Deer, Howie, and Zussman 1978) shows that the type $C$ crystals have compositions in the range given for augite. Type $B$ resembles omphacite in sodium content but has much higher iron and lower calcium. The type $B$ and $C$ pyroxene crystals in BGC-35-1 showed similar sizes and shapes, and therefore could not be distinguished by microscopic observation alone.

BGC-35-1 also contained several other minor phases, two of which were analyzed by EDX microanalysis and designated $D$ and $E$. These were not identified by electron diffraction. Type $D$ is an iron oxide with relatively little titanium and may be the Fd3M cubic special magnetite. Type E crystals, having a Fe:Ti ratio near one, were not common.

BGC-35-2 has the same composition as BGC-35-1, but was crystaliized at a higher temperature. The microstructure is much coarser than that of BGC-35-1; many of the crystals reaching several micrometers across. Figure 14 shows the structure at relatively high magnification, using darkfield TEM for crystal identification. However, the lower magnification SEM micrograph in Figure 10 gives a better overall view of the microstructure.

Two types of large crystals are present in BGC-35-2, and these account for most of its crystallinity. The 0.3 to $1.5 \mu \mathrm{m}$ blocky crystals are type A titaniferous hematite. Despite the difference in morphology from the type A crystals in $B G C-35-1$, the type $A$ crystal compositions given in Table 9 are similar in both specimens and the single-crystal diffraction patterns show no differences in spot positions. Three other large crystals, which range from 1 to $3 \mu \mathrm{m}$ across, are type $C$ clinopyroxenes. Based on their compositions, type $C$ crystals were identified as augite. Type $B$ pyroxenes were also found in BGC-35-2, but occurred as sma $11,0.15 \mu \mathrm{m}$ equiaxed crystals which did not 
account for much of the total crystallinity. Another minor phase identified in $B G C-35-2$ is the type $F$ calcium phosphorous silicate. Type $F$ crystals were not identified by a crystal structure, but may be apatite.

SBGC-63 exhibited the largest-scale phase separation in the parent glass. As previously mentioned, the SEM micrograph in Figure 12 shows ring-like structures which correspond in size to these segregated zones. The segregation in the glass appears to have affected subsequent crystallization behavior. Unfortunately, the ion micromilled TEM specimen of SBGC-63 had relatively little thin area, and did not reveal the segregation structure. Since only part of the structure was observed in the TEM specimens, important crystal types may. have been missed. The areas which were examined by TEM showed uniformly distributed crystals with sizes up to about $0.25 \mu \mathrm{m}$ as seen in Figure 15. Type A hematite-ilmenite crystals in this specimen had the same blocky shapes as those in $B G C-35-2$, but had side lengths of only 0.1 to $0.25 \mu \mathrm{m}$. Type $C$ augite crystals were equiaxed and about $0.25 \mu \mathrm{m}$ in diameter whereas the common type $B$ pyroxenes were much smaller (about $0.05 \mu \mathrm{m}$ ). No type D crystals and few types $E$ and $F$ crystals were found in SBGC-63.

SEM examination of BGC-50 showed scattered 0.7 um crystals surrounded by smaller crystals near the resolution limit of the microscope. The smaller crystals were easily resolved in TEM of ion micromilled specimens, and were identified by EDX microanalysis and selected area diffraction. The crystals were embedded in a continuous glass matrix and ranged from $0.7 \mu \mathrm{m}$ to less than $0.02 \mu \mathrm{m}$ in size. Ion micromilling tended to attack the glass matrix surrounding the larger crystals, leaving skeletal rings of material as shown in Figure 16a. These rings correspond roughly in size to the dispersed glass phase droplets in the parent glass, and are thought to correspond to the droplet perimeters. Figure $16 \mathrm{~b}$ is a darkfield micrograph showing a thicker region in which the material inside a ring remains intact. A single large crystal appeared at the center of the ring and is surrounded mainly by glass containing few crystals.

Six distinct phases including the glass matrix were identified by their characteristic compositions given by EDX microanalyses. The crystals are 
identified by letters $A$ through $E$ in Figures $16 a$ and $10 \bar{b}$, and the composition ranges are given in Table 9. The larger crystals were also identified by single-crystal electron diffraction.

In all four materials, the residual glass phase left after crystallization is mainly silicon, with some aluminum, calcium, iron and sodium. The residual glass compositions are given in Table 11. Apparent sodium concentrations of the glass varied with the thickness of the analyzed region. The thinnest regions showed anomalously high sodium - in one case 23 wt $\% \mathrm{Na}_{2} \mathrm{O}$ - raising the suspicion that a sodium-enriched surface layer may be left by ion micromilling or may be caused by the STEM electron beam. Nevertheless, the sodium content of the residual glass is consistently higher than that of the crystals. Therefore, it appears that most of the sodium remains in the residual glass after crystallization.

The four glass ceramics did not lend themselves we 11 to analysis by XRD because the majority of peaks could be attributed to more than one of the major phases identified by STEM. Figures 17 and 18 show the XRD traces. As seen by the peak identification, the unequivocal peaks for the titaniferous hematite are at $24.0,32.9,49.2,53.7$, and 63.8 degrees $2 \theta$. One phase found by XRD which was not seen in STEM analysis has a spinel structure and is probably ulvospinel, $2 \mathrm{FeO} \cdot \mathrm{TiO}_{2}$. This phase was identified in the trace for SBGC-63, Figure 18. The spinel was probably not seen in the STEM analys is of SBGC-63 because of the 1 imited area studied in the inhomogeneous structure. Traces of the spinel may be present in the other three glass-ceramics. The only unequivocal peak for the spinel phase is at 36.0 degrees 20 . This can be seen in Figure 18. The clinopyroxene (fassaite) and augite phases (Types $B$ and $C$ in the STEM analysis) have closely grouped peaks with only one unequivocal peak for fassaite at 39.3 degrees 20 . Unknown phases contribute peaks at $21.9,25.7,26.5$ and 31.8 degrees $2 \theta$.

A rough estimate of the relative amounts of the major phases was made by comparison of the unequivocal peak integrated areas between samples and overall composition of total integrated areas with a standard material. The standard used was 20 wt\% trevorite $\left(\mathrm{NiFe}_{2} \mathrm{O}_{4}\right)$ with $80 \mathrm{wt} \%$ vitreous waste glass filler. Table 12 shows the estimated weight percent of the phases. 


\section{LEACH TESTING}

\section{Procedure}

Chemical durability of the materials was determined using the Materials Characterization Center Test MCC-1, details of which are published elsewhere (MCC 1981). MCC-1 is a static leaching test utilizing single monolithic samples and relying on chemical analyses of the resulting solution for elemental release data. Samples were leached in deionized water with a geometric sample surface area to solution volume ratio of $10 \mathrm{~m}^{-1}$. Tests were performed in Teflon ${ }^{\circledR}$ jars placed in a $90^{\circ} \mathrm{C} \pm 1^{\circ} \mathrm{C}$ oven for periods of 3 to 93 days. Upon removal from the ovens, the $\mathrm{pH}$ of the solution was determined using a Markson(a) probe and meter. The jar was then acid stripped to remove any leached products that may have adsorbed on the container wall, and the resulting acidified solution was then analysed for cations by ICP.

The results of the static leach tests were calculated using the following equation:

$$
(N L)_{i}=\frac{m_{i}}{f_{i} \cdot S A}
$$

where $(N L)_{i}=$ the normalized mass of element " $i$ " lost per unit surface area of the sample

$$
m_{i}=\text { the mass of element " } i \text { " in solution }(g)
$$$$
f_{i}=\text { the mass fraction of element " } i \text { " in the sample when the }
$$
test began (unitless)

$S A=$ geometric surface area of the sample $\left(m^{2}\right)$

The mass fraction of the elements in the samples was determined by analyzing bulk materials using a KOH fusion followed by ICP analysis. The analyzed composition of the three materials are listed in Table 6. Bulk compositions of

Registered trademark of E.I. duPont De Nemours Co., Inc.

(a) Markson Science Inc. 
the glass ceramics are assumed to be the same as those of the corresponding parent glass. Normalization of the elemental mass losses with respect to the bulk material composition has the advantage of allowing easy comparison of the behavior of the different elements within the sample. If the normalized releases are equal for all elements, the sample is dissolving congruently. Such behavior would be expected of very soluble materials such as $\mathrm{NaCl}$. If the nomalized release of an element is significantly lower than other elements, then the element has either reached saturation in the solution and is precipitating back onto the sample or the container, or it is never leaving the leached layer of the material.

Elemental Release Results

The glass ceramics were found to dissolve significantly more slowly than the parent glasses, although leach solutions for both materials approached the same $\mathrm{pH}$ at the longer leaching times. The continuous glassy matrix phase in both materials was shown to be dissolving while the dispersed phase droplets in the parent glass and the crystals in the glass ceramic remained unleached.

The normalized elemental mass losses for the parent glasses and glass ceramics are listed in Table 13. Three samples of each material were tested at 28 days, with the average values and their standard deviations reported. These 28-day standard deviations provide a reasonable measure of the experimental error which is generally less than $10 \%$ of the reported values. While all four glass ceramics were tested for longer periods, only one parent glass, $B G-50$, was tested beyond 28 days. Comparison of Table 13 with the compositions of the materials in Table 6 reveals a number of elements that were either below detection limits in the leach solutions or so close to detection limits that experimental errors were large. $\mathrm{Cr}, \mathrm{Cu}, \mathrm{P}, \mathrm{Zn}$, and $\mathrm{Ce}$ were below detection limits in all cases, while $\mathrm{Ba}, \mathrm{Mn}, \mathrm{Sr}$, and $\mathrm{Ti}$ were barely detectable.

Table 13 illustrates the similarity in behavior of the parent glasses. At 28 days, for example, none of the elemental releases vary by more than a factor of two between $B G-35, B G-50$, and SBG-63. The same is true for the glass ceramics out to 93 days. The close similarity in leaching behavior is expected 
because all the materials are very close in overall composition (Table 6) and the glass ceramics have similar phase compositions (Table 12). The discussion of the leaching results, therefore, is based only on the releases from the 50 wt $\%$ waste-loaded parent glass $(B G-50)$ and glass ceramic (BGC-50) (Figures 19 through 24).

Figure 19 shows the leachate solution $\mathrm{pH}$ versus time for $\mathrm{BG}-50$ and $B G C-50$. After an initial rapid rise, the $\mathrm{pH}$ peaks after 15 to 20 days for the parent glass and then declines toward pH 8. The glass ceramic leachate $\mathrm{pH}$ goes through a minimum at about 3 days and then also approaches pH 8 at long times. The elemental releases fall into three catagories: those released below detectable limits, those continuing to be released from the glass ceramics at longer times, and those which have appeared to reach saturation in long-term glass testing of the ceramics.

Iron is released at detectable but low levels from both parent glasses and glass ceramics, as seen in Table 13. Even at the longer times, the normalized release is less than $1 / 20$ that of $\mathrm{Si}$. Neither $\mathrm{P}$ nor $\mathrm{Ti}$ are detectable in the leach solutions. If they had reached their respective ICP detection limit concentrations in the leachate $(0.2 \mathrm{ppm}$ for $\mathrm{P}$ and $0.002 \mathrm{ppm}$ for Ti), their normalized releases would have been much less than that for $S i$ at 56 days in the parent glass, $B G-50\left(1.7 \mathrm{~g} / \mathrm{m}^{2}\right.$ for $P$ an $0.008 \mathrm{~g} / \mathrm{m}^{2}$ for $\left.\mathrm{Ti}\right)$. These elements, as well as $\mathrm{Cr}, \mathrm{Cu}, \mathrm{Mn}, \mathrm{Sr}, \mathrm{Zn}$, and $\mathrm{Ce}$, are probably remaining on or in the leached layer rather than forming suspended precipitates or adsorbing on the container walls since acidification of the leachates and acid stripping of the leach containers failed to dissolve them in detectable amounts. No release curve is plotted for $\mathrm{Fe}$ since its releases are small and exhibit much scatter (Table 13).

Figures 20,21 , and 22 show the normalized release curves for Si, Al, and Na. The cumulative releases from the parent glass increase rapidly for the first one or two weeks, then rise at more moderate rates to between 6 and $9 \mathrm{~g} / \mathrm{m}^{2}$ at 56 days. The releases from the glass ceramic, BGC-50, are slower, being almost linear up to 93 days, releasing 1.7 to $2.1 \mathrm{~g} / \mathrm{m}^{2}$ at 56 days. Thus, 
although $\mathrm{Si}, \mathrm{Al}$, and $\mathrm{Na}$ continue to be released from both the parent glass and the glass ceramic at long times, their releases from the glass ceramic are roughly one quarter of their levels from the parent glass.

Figures 23 and 24 show $\mathrm{Ca}$ and $\mathrm{Mg}$ releases. These plots are similar to those for $\mathrm{Si}, \mathrm{Al}$, and $\mathrm{Na}$, except that both the $\mathrm{Ca}$ and $\mathrm{Mg}$ concentrations appear to temporarily saturate between 1 and 4 weeks in the parent glass leachates and to saturate at longer times and lower levels in the glass ceramic leachates. At 56 days $\mathrm{Ca}$ and $\mathrm{Mg}$ concentrations in the parent glass leachate are at about $10 \%$ of their level at 56 days in the glass ceramic leachate.

SEM Analys is of Leached Samples

Scanning electron microscopy (SEM) and energy dispersive $x$-ray analysis (EDAX) provide some clues which help explain the leach data. The test materials were characterized before and after leaching in both surface and polished cross-section views. Since the differences were slight between the various waste loadings, only representative data and micrographs are included. Analysis of polished cross sections is presented first, followed by that of sample surfaces.

Figure 25 shows four SEM micrographs of parent glass BG-50 after leaching; Figure 25b is a detailed view of the leached "tunnel" at center left in Figure $25 \mathrm{a}$. This sample was leached for 28 days. Figure $25 \mathrm{~d}$ details the center of Figure 25c, a 41-day leached sample. The spherical bodies remaining in the leached layer are apparently the dispersed phase resulting from the liquidliquid phase separation seen in Figure 8 . The matrix glass phase dissolves during leaching, leaving the Fe-Ti rich spheres embedded in a low density gel. Assuming that $50 \%$ of the mass is removed from a $4-\mu \mathrm{m}$ thick layer (the approximate average gel thickness in Figure 25c), then sufficient material is supplied to account for the release data from the 41-day sample in Table 13. Thus, it is reasonable to assume that the gel layer remains substantially intact at least up to 41 days; that is, following the initial leaching, the gel layer with embedded spheres is not itself dissolved. 
Figure 26 shows EDAX spectra generated from the bulk, unleached material in Figure 25a and from the leached "tunnel" in Figure 25b. Compared to the bulk material, the leached material is noticeably depleted in $\mathrm{Mg}, \mathrm{Al}, \mathrm{Si}$, and $\mathrm{Ca}$, and enriched in $\mathrm{Ti}$ and $\mathrm{Fe}$.

Figure 27 shows increasing magnifications of the surface of glass ceramic BGC-50 leached 67 days. The gel portion in Figure $27 \mathrm{c}$ is atypical, being much thicker than that on most of the sample. The average thickness is considerably less than one micron.

Figure 28 shows the 67-day leached layer on glass ceramic BGC-35-2. Figure $28 \mathrm{c}$ suggests that the residual glass is being leached away, leaving crystals embedded in a low density gel. The average thickness of the leached layer is less than one micron.

Surfaces of leached and unleached materials are compared in Figure 29. Figure 29a and b show the as-prepared (diamond-sawed) surfaces of the parent glass and the glass ceramic, BG-50 and BGC-50. Figures $29 \mathrm{c}$ and $d$ show the surfaces resulting from 28 days of leaching. The parent glass surface in Figure $29 \mathrm{c}$ exhibits softened edges and white precipitate clusters. The leached glass ceramic surface in Figure $29 d$ has somewhat sharper edges and displays evenly distributed cylindrical shapes which are probably crystals or cyrstal clusters exposed as the residual glass is leached away.

Figure 30 shows higher magnifications of the leached surfaces of BG-50 and BGC-50. The pitted surface underlying the precipitate clusters is visible on the parent glass micrograph (30a). The rod-shaped particles exposed on the surface of the leached glass ceramic (30b) are $\sim 0.3-0.5 \mu \mathrm{m}$ in length and $\sim 0.1 \mu \mathrm{m}$ in diameter. These dimensions correspond to the ilmenite-hematite phase identified by STEM and labeled as phase $A$ in Figure 13.

Figure 31 shows EDAX spectra taken over large areas on the surfaces before and after leaching. Figures $31 \mathrm{a}$ and $\mathrm{b}$ are from the parent glass and glass ceramic before leaching. Figure $31 \mathrm{c}$ shows the spectra of the parent glass after 28-day leaching. This spectrum shows depletion in $\mathrm{Al}$ and $\mathrm{Si}$ and enhancement of $\mathrm{P}, \mathrm{Ti}$, and $\mathrm{Fe}$. There is only slight depletion of $\mathrm{Ca}$. The spectrum of the leached glass ceramic surface (31d), however, is unchanged from the spectrum before leaching (31b) except for a slight depletion of Si. 
The parent glass SBG-63 displays well-formed precipitate clusters on its leached surface, as seen in Figure 32b. Figure 33 shows EDAX spectra of SBG-63 surfaces. Figures $33 a$ and $b$ are large area scans before and after leaching. As with BG-50, the leached surface is depleted in $A 1$ and $S i$ and enriched in $P$, $\mathrm{Ti}$, and Fe. Unlike BG-50, the SBG-63 surface appears to be enriched in $\mathrm{Ca}$. This may be due to the more extensive precipitation on SBG-63. Spectra in $33 \mathrm{C}$ and $d$ are from the large precipitate cluster and a bare spot between the clusters shown in Figure 32a. Relative to the overall leached surface spectrum (33b), the precipitate spectrum (33c) is enriched in Si, P, and Ca. In the same comparison, the spectrum from between the precipitate clusters (D) is depleted in $\mathrm{P}$ and $\mathrm{Ca}$ and enriched in $\mathrm{Si}$ and $\mathrm{Al}$.

\section{DISCUSSION}

A main objective of this study was to explain why crystallization results in an increase in chemical durability in basalt-based waste forms. The explanation developed below is that the heat treatment results in crystallization of clinopyroxenes which reduces the concentration of alkaline earth elements in the residual glass. Removal of some of the alkaline earths from the residual glass results in a more chemically durable structure with fewer nonbridging oxygens per $S i$ than in the matrix phase of the parent glass. Another topic deserving mention is that of the apparent action of a buffer system that controls the $\mathrm{pH}$ without affecting the leach rate. Lastiy, the possible role of basalt-based waste forms in nuclear waste management is addressed.

The increase in chemical durability due to crystallization, illustrated in Figures 25,27, and 28, suggest that the dissolution rates of two continuous glassy matrix phases are involved. Unfortunately, only measurements of the composition of the glass ceramic matrix phase were obtained. The composition of the matrix glass phase in the parent glass was only estimated. The bulk composition of the waste form is repeated in Column $A$ of Table 14. To estimate the composition of the parent glass matrix phase, it is assumed that the change in composition from the bulk can be accounted for by the simple removal of 15 wt\% of the average hematite composition. Based on Figure 8 , 
most of the $\mathrm{Fe}$ and $\mathrm{Ti}$ reside in the dispersed phase of the optically dark minerals. The total volume percent of the dispersed phase is substantially greater than $15 \%$ and since most of the heavier elements reside therein, the total weight percent must still be larger. Therefore, the dispersed phase must contain some $\mathrm{Si}$ and probably some of all the other elements in the glass besides $\mathrm{Fe}$ and $\mathrm{Ti}$. However, for the purpose of this estimation, it is assumed that the proportions of the element in the dispersed phase besides $\mathrm{Fe}$ and $\mathrm{T} i$ are the same as their proportions in the bulk material. Column B contains only $\mathrm{Fe}_{2} \mathrm{O}_{3}$ and $\mathrm{TiO}_{2}$ in the ratio found in the average titaniferrous hematite in Table 9. The parent glass matrix is calculated in Column $C$ by removing $15 \%$ of Column $B$ from Column $A$ and renormalizing. The average of 13 measurements of the residual glass in the glass ceramic by TEM/EDAX is listed in Column $D$.

Comparison of Columns $C$ and $D$ reveals that the two matrix glasses probably contain similar amounts of $\mathrm{Si}$ and $\mathrm{Al}$ but differ in the concentrations of the other elements. Changes caused by crystallization, which would be expected to have significant effects on dissolution rate, are those for $\mathrm{Fe}, \mathrm{Ca}, \mathrm{Mg}$, and $\mathrm{Na}$. The glass ceramic matrix is estimated to be enriched in $\mathrm{Fe}$ and $\mathrm{Na}$, and depleted in $\mathrm{Mg}$ and $\mathrm{Ca}$ relative to the parent glass matrix. The factor of two enrichment of Fe would be beneficial to chemical durability (Paul and Zaman 1978). The $-50 \%$ increase of $\mathrm{Na}$ in the glass ceramic matrix would be expected to decrease chemical durability. However, the effect of reducing alkaline earth concentrations by half may overcome the detrimental effect of increased Na. Based only on $\mathrm{Ca}, \mathrm{Mg}, \mathrm{Na}$, and $\mathrm{Si}$, the calculated ratio of non-bridging oxygen atoms per silicon atom in the parent glass matrix is 0.9 while for the glass ceramic matrix this ratio is 0.7 , indicating that dissolution of the parent glass matrix would require the breaking of fewer bonds than for dissolution of the glass ceramic matrix. Other investigators have found that in simple sodalime-silica glasses, the addition of $\mathrm{CaO}$ increases durability up to a point, after which further additions cause increased dissolution (Paul 1977, Budd and Frackiewicz 1962). The $\mathrm{CaO} / \mathrm{Na}_{2} \mathrm{O}$ (mole) ratio found by Paul to produce optimum durability was in the range 0.7-1.0. For the parent glass matrix, the $(\mathrm{CaO}+\mathrm{MgO}) / \mathrm{Na}_{2} \mathrm{O}$ mole role is 3.6 , far in excess of the ideal range, while 
for the glass ceramic matrix the ratio is 1.1 , nearly within the optimum range. This may indicate why the glass ceramic matrix structure is more chemically durable than that of the parent glass matrix. Thus, the crystallization of the alkaline earth-rich clinopyroxene is believed to be responsible for the increase in chemical durability of basalt waste forms after heat treatment.

The leachates of both the parent glass and the glass ceramic appear to approach a pH of about 8 at the longer times (Figure 19); yet the concentration of species in solution remains much different. It is probable that the $\mathrm{pH}$ is being controlled by a buffer system which determines the ratios between concentrations of species in solution rather than the magnitudes of their concentrations. The controlling equilibria and species involved were not determined in this study.

The basalt glass ceramic is compared to other TRU nuclear waste forms on the basis of 28-day static leaching data in Table 15. The six waste forms were prepared with simulated TRU waste containing ${ }^{239} \mathrm{Pu}$ (Chikalla and Powe 11 1981). The basalt glass ceramic produced with ${ }^{239} \mathrm{Pu}$ is very similar to the non-radioactive material discussed here, although the Pu-containing material produced lower leach rates than those reported in Table 13.

The $\mathrm{Pu}$ release for the basalt glass ceramic $\left(0.02 \mathrm{~g} / \mathrm{m}^{2}\right)$ is much lower than for the matrix elements, $\mathrm{Al}, \mathrm{Ca}, \mathrm{Na}$, and $\mathrm{Si}$. $\mathrm{Pu}$ is released at the relatively slow rate comparable to that for $\mathrm{Fe}$ and $\mathrm{Ti}$. The location of $\mathrm{Pu}$ in the structure could not be determined from alpha autoradiography, although it was found to be well dispersed on a macro scale (Chikalla and Powel1 1981). The Pu may reside in one of the crystal phases, or it may exist as well dispersed $\mathrm{PuO}_{2}$ microcrystals in the residual glass phase.

Comparison of leaching results with the other waste forms (Table 15) shows that the basalt glass ceramic matrix dissolves relatively slowly, having the lowest $\mathrm{Fe}, \mathrm{Ca}, \mathrm{Na}$, and $\mathrm{Si}$ releases and the second lowest $\mathrm{Al}$ release. However, the $\mathrm{Pu}$ is second highest. This is probably because the Pu release is solubility limited, with the solubility of Pu increasing as the $\mathrm{pH}$ decreases (Rai and Ryan 1981). Thus, depending upon the specific repository conditions, containment of Pu may not be improved by having a low waste form matrix dissolution 
rate. However, in situations where solubility would not limit Pu release, such as for high water flow rates, the basalt glass ceramic would be expected to fall among the waste forms with the lowest $\mathrm{Pu}$ release rates.

Basalt-based waste forms are promising materials for radioactive waste immobilization, not only because they exhibit low leach rates, they also appear to offer practical advantages over many tailored crystalline ceramic waste forms because the basalt glasses and glass ceramics are relatively insensitive to processing parameters (time and temperature) and to variations in composition. Leach rates do not vary greatly with changes in heat treatment or waste loading, probably because the durability of the glass ceramics depends on the matrix glass which is, because of its amorphous structure, able to accommodate reasonable variation in composition without extreme or discontinuous effects on its properties. 



\section{REFERENCES}

Ames, L. L. 1980. Hanford Basalt Flow Mineralogy, PNL-2847, Pacific Northwest Laboratory, Richland, Washington.

Beal1, G. H. and H. L. Rittler. 1976. "Basalt Glass Ceramics," Bull. Am. Ceram. Soc. 55 (6):579.

Brouns, R. A. and C. L. Timmerman. 1982. In-Situ Thermoelectric Stabilization of Radioactive Waste, PNL-SA-9924, Pacific Northwest Laboratory, Richland, Washington. To be published in Proceedings of Waste Management ' 82 held March 8-11, 1982, Tucson, Arizona.

Budd, S. M. and J. Frackiewiez. 1962. Physics and Chemistry of Glasses, p. $116,3(1962)$.

Chikalla, T. D. and J. A. Powe 11. 1981. Nuclear Waste Management Quarterly Progress Report April Through June 1981, PNL-3000-10, Pacific Northwest Laboratory, Richland, Washington.

Deer, W. A., R. A. Howie, and J. Zussman. 1978. Rock Forming Minerals, Volume 2A, Single-Chain Silicates (2nd Ed.), Longmans, London, England.

Donath, F. A. 1978. "Relation of Solids to Nuclear Waste I solation," pp. 13-29 in Proceedings of the Conference on High-Level Radioactive Solid Waste Forms, NUREG/CP0005, L. A. Casey, Editor, U.S. Nuclear Regulatory Commission, Office of Nuclear Material Safety and Safeguards, Conference held December 19-21, 1978 at Denver, Colorado.

Lindsley, D. H. 1976. "The Crystal Chemistry and Structure of 0xide Minerals as Exemplified by Fe-Ti 0xides," pp. 61-659, in 0xide Minerals, Vol. 3, D. Rumble II (Ed.), Mineral Society of America, Washington, DC, 1976.

Lokken, R. 0. 1981. Leaching Behavior of Glass Ceramic Nuclear Waste Forms, PNL-4022, Pacific Northwest Laboratory, Richland, Washington.

MCC. 1981. Nuc lear Waste Materials Handbook, Volume I, Test Methods, DOE/TIC-11400, Pacific Northwest Laboratory, Richland, Washington.

Paul, A. 1977. "Chemical Durability of Glasses; a Thermodynamic Approach," pp. 2246-2268, Journal of Materials Science 12(1977).

Paul, A. and M. S. Zaman. 1978. "The Relative Influences of $\mathrm{Al}_{2} \mathrm{O}_{3}$ and $\mathrm{Fe}_{2} \mathrm{O}_{3}$ on the Chemical Durability of Silicate Glasses at Different pH Values," pp. 1499-1502, Journal of Materials Science 13(1978). 
Rai, D. and J. L. Ryan. 1981. Crystallinity and Solubility of Pu (IV) Oxide and Hydroxide in Aged Aqueous Solutions, PNL-SA-9722, Pacif ic Northwest Laboratory, Richland, Washington.

Timmerman, C. L. 1980. Description of Processes for the Immobilization of Selected Transuranic Wastes, PNL-3479, Pacific Northwest Laboratory, Richland, Washington. 
TABLE 1. Chemical Compositions of Typical Sludge, Ash, Waste Blend, and Pomona Basalt

Composition, wt \%

\begin{tabular}{|c|c|c|c|c|}
\hline \multirow[b]{2}{*}{ Compound } & \\
\hline & $\begin{array}{c}\text { Process } \\
\text { Sludge }(a)\end{array}$ & $\begin{array}{l}\text { Inc inerator } \\
\text { Ash }(a, b)\end{array}$ & $\begin{array}{c}\text { Waste } \\
\text { Blend }(\mathrm{c})\end{array}$ & Basalt $(d)$ \\
\hline $\mathrm{Al}_{2} \mathrm{O}_{3}$ & 1.48 & $18.59^{(\mathrm{e})}$ & 5.76 & 13.9 \\
\hline $\mathrm{B}_{2} \mathrm{O}_{3}$ & - & 0.32 & 0.08 & -- \\
\hline $\mathrm{BaO}$ & - & 0.97 & 0.24 & -- \\
\hline $\mathrm{CaO}$ & 7.61 & 4.00 & 6.71 & 10.2 \\
\hline$C$ & - & 9.70 & 2.43 & -- \\
\hline $\mathrm{Co}_{2} \mathrm{O}_{3}$ & - & 0.01 & - & - \\
\hline $\mathrm{Cr}_{2} \mathrm{O}_{3}$ & - & 0.10 & 0.03 & -- \\
\hline CuO & -- & 0.02 & -- & -- \\
\hline $\mathrm{Fe}_{2} \mathrm{O}_{3}$ & 21.95 & 1.43 & 16.82 & 11.7 \\
\hline $\mathrm{K}_{2} \mathrm{O}_{3}$ & 0.64 & 0.97 & 0.72 & - \\
\hline $\mathrm{MgO}$ & 3.50 & 5.34 & 3.96 & 6.7 \\
\hline $\mathrm{MnO}_{2}$ & - & 0.02 & - & 0.2 \\
\hline $\mathrm{MoO}_{3}$ & - & 0.02 & - & - \\
\hline $\mathrm{Na}_{2} \mathrm{O}$ & 6.20 & 1.82 & 5.10 & 2.7 \\
\hline $\mathrm{NiO}$ & - & 0.04 & 0.01 & -- \\
\hline$P_{2} O_{5}$ & 3.99 & 4.81 & 4.19 & - \\
\hline $\mathrm{SiO}_{2}$ & $37.58^{(\mathrm{e})}$ & $25.48^{(e)}$ & 34.55 & 51.7 \\
\hline Sro & -- & 0.02 & -- & -- \\
\hline$S$ & - & 0.36 & 0.09 & - \\
\hline $\mathrm{TiO}_{2}$ & - & $24.26^{(\mathrm{e})}$ & 6.07 & 1.6 \\
\hline $\operatorname{Zno}$ & - & 1.67 & 0.42 & -- \\
\hline $\mathrm{ZrO}_{2}$ & - & 0.03 & 0.01 & - \\
\hline $\mathrm{H}_{2} \mathrm{O}$ & 10.00 & -- & 7.50 & -- \\
\hline $\mathrm{PuO}_{2}$ & 0.002 & 0.2 & 0.05 & - \\
\hline \multirow[t]{2}{*}{ Other } & 7.05 & -- & 5.29 & -- \\
\hline & 100.002 & 100.18 & 100.03 & 98.7 \\
\hline
\end{tabular}

(a) Assumed compositions (Timmerman, 1980).

(b) Unleached.

(c) Based on sludge: ash generation-rate ratio of 3 .

(d) By ICP analysis.

(e) Highly variable. 
TABLE 2. Heat Treatment Matrix

\begin{tabular}{|c|c|c|c|}
\hline \multicolumn{2}{|c|}{ Nucleation } & \multicolumn{2}{|c|}{ Crystal Growth } \\
\hline $\begin{array}{l}\text { Temperature } \\
\left({ }^{\circ} \mathrm{C}\right)\end{array}$ & $\begin{array}{l}\text { Time } \\
(\mathrm{h})\end{array}$ & $\begin{array}{c}\text { Temperature } \\
\left({ }^{\circ} \mathrm{C}\right)\end{array}$ & $\begin{array}{l}\text { Time } \\
(\mathrm{h})\end{array}$ \\
\hline 700 & 0.5 & 950 & 1 \\
\hline & & 950 & 4 \\
\hline & & 950 & 8 \\
\hline 700 & 2 & 950 & 1 \\
\hline & & 950 & 4 \\
\hline & & 950 & 8 \\
\hline & & 1000 & 1 \\
\hline & & 1000 & 8 \\
\hline & & 1050 & 1 \\
\hline & & 1050 & 8 \\
\hline 700 & 6 & 950 & 8 \\
\hline 750 & 2 & 950 & 8 \\
\hline 800 & 2 & 950 & 8 \\
\hline
\end{tabular}


TABLE 3. Total Crystallinity of Basalt Glass Ceramics After Various Heat Treatments

\begin{tabular}{|c|c|c|c|c|c|c|c|c|}
\hline \multirow{2}{*}{$\begin{array}{l}\text { Data } \\
\text { Group }\end{array}$} & \multicolumn{2}{|c|}{ Nucleation } & \multicolumn{2}{|c|}{$\begin{array}{l}\text { Crystal } \\
\text { Growth }\end{array}$} & \multicolumn{4}{|c|}{ Total Crystallinity, wt $\%$} \\
\hline & $\mathrm{T},{ }^{\circ} \mathrm{C}$ & $t, h$ & $\mathrm{~T},{ }^{\circ} \mathrm{C}$ & $\overline{t, h}$ & $B G-20$ & $B G-35$ & $B G-50$ & $T B W-R-G$ \\
\hline \multirow[t]{3}{*}{1} & 700 & 0.5 & 950 & 1 & 26 & 27 & 19 & 25 \\
\hline & 700 & 0.5 & 950 & 4 & 35 & 35 & 28 & 27 \\
\hline & 700 & 0.5 & 950 & 8 & 31 & 31 & 28 & 34 \\
\hline \multirow[t]{3}{*}{2} & 700 & 0.5 & 950 & 8 & 31 & 31 & 28 & 34 \\
\hline & 700 & 2 & 950 & 8 & 34 & 32 & 30 & 35 \\
\hline & 700 & 6 & 950 & 8 & 32 & 29 & 28 & 27 \\
\hline \multirow[t]{3}{*}{3} & 700 & 2 & 950 & 8 & 34 & 32 & 30 & 35 \\
\hline & 750 & 2 & 950 & 8 & 31 & 33 & 30 & 32 \\
\hline & 800 & 2 & 950 & 8 & 34 & 33 & 34 & 31 \\
\hline \multirow[t]{3}{*}{4} & 700 & 2 & 950 & 1 & 24 & 21 & 19 & 25 \\
\hline & 700 & 2 & 1000 & 1 & 31 & 31 & 29 & 29 \\
\hline & 700 & 2 & 1050 & 1 & 33 & 30 & 34 & 29 \\
\hline \multirow[t]{3}{*}{5} & 700 & 2 & 950 & 8 & 34 & 32 & 30 & 35 \\
\hline & 700 & 2 & 1000 & 8 & 32 & 34 & 31 & 33 \\
\hline & 700 & 2 & 1050 & 8 & 42 & 44 & 33 & 28 \\
\hline
\end{tabular}


TABLE 4. Nucleation/Crystallization Conditions Applied to Basalt Glass with 50 wt\% TBW-R

\begin{tabular}{|c|c|c|c|c|}
\hline \multirow{2}{*}{$\begin{array}{l}\text { Heat } \\
\text { Treatment } \\
\text { Number } \\
\end{array}$} & \multicolumn{2}{|c|}{ Nucleation } & \multicolumn{2}{|c|}{ Crystal Growth } \\
\hline & $\begin{array}{c}\text { Temperature } \\
\left({ }^{\circ} \mathrm{C}\right)\end{array}$ & $\begin{array}{l}\text { Time } \\
(\mathrm{h})\end{array}$ & $\begin{array}{c}\text { Temperature } \\
\left({ }^{\circ} \mathrm{C}\right)\end{array}$ & $\begin{array}{l}\text { Time } \\
(\mathrm{h})\end{array}$ \\
\hline 1 & 700 & 0.5 & - & - \\
\hline 2 & 700 & 2 & - & - \\
\hline 3 & 700 & 6 & - & - \\
\hline 4 & 675 & 2 & - & - \\
\hline 5 & 725 & 2 & - & - \\
\hline 6 & 750 & 2 & - & - \\
\hline 7 & 775 & 2 & - & - \\
\hline 8 & 800 & 2 & - & - \\
\hline 9 & 825 & 2 & - & - \\
\hline 10 & 850 & 2 & - & - \\
\hline 11 & 700 & 2 & 950 & 1 \\
\hline 12 & 700 & 2 & 950 & 2 \\
\hline 13 & 700 & 2 & 950 & 4 \\
\hline 14 & 700 & 2 & 950 & 8 \\
\hline 15 & 750 & 2 & 950 & 8 \\
\hline 16 & 800 & 2 & 950 & 8 \\
\hline 17 & 700 & 2 & 850 & 8 \\
\hline 18 & 700 & 2 & 900 & 8 \\
\hline 19 & 700 & 2 & 1000 & 8 \\
\hline 20 & 700 & 2 & 1050 & 8 \\
\hline 21 & 700 & 2 & 1100 & 8 \\
\hline
\end{tabular}


TABLE 5. Oxide Compositions of TBW-R, Pomona Basalt, and Synthetic Basalt Additives

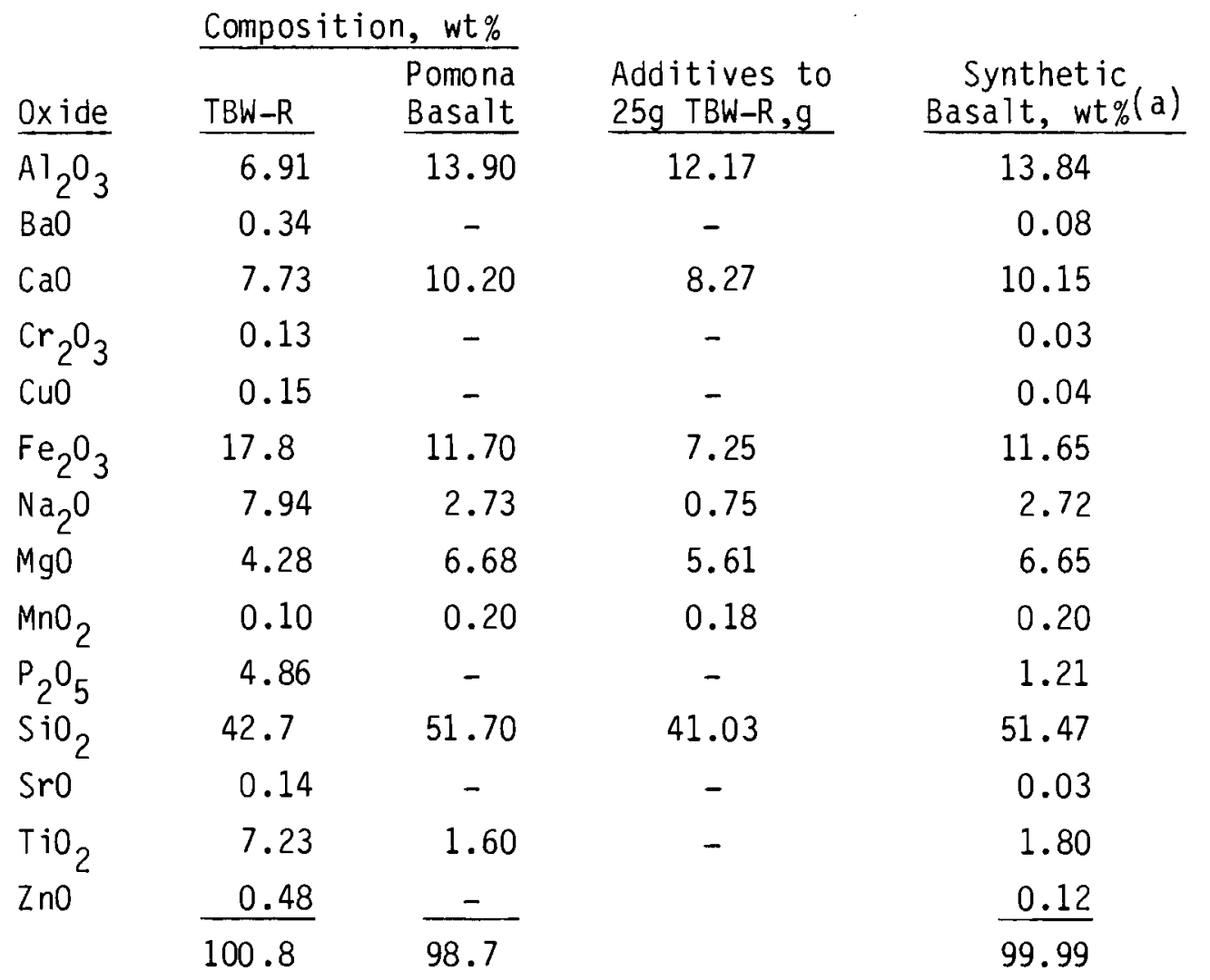

(a) Synthetic basalt contains $25 \mathrm{wt} \%$ TBW-R and $75 \mathrm{wt} \%$ of the chemicals listed in column 3. 
TABLE 6. Compositions of Parent Glasses Determined by KOH Fusion/ICP Composition, wt \%

\begin{tabular}{|c|c|c|c|}
\hline Oxide (a) & $B G-35$ & $B G-50$ & SBG-63 \\
\hline $\mathrm{Al}_{2} \mathrm{O}_{3}$ & 10.9 & 10.1 & 9.4 \\
\hline $\mathrm{BaO}$ & 0.2 & 0.2 & 0.2 \\
\hline $\mathrm{CaO}$ & 9.1 & 8.8 & 9.1 \\
\hline $\mathrm{Cr}_{2} \mathrm{O}_{3}$ & 0.1 & 0.1 & 0.1 \\
\hline $\mathrm{Cu}_{2} \mathrm{O}$ & 0.1 & 0.1 & 0.1 \\
\hline $\mathrm{Fe}_{2} \mathrm{O}_{3}$ & 14.6 & 15.4 & 15.4 \\
\hline $\mathrm{MgO}$ & 5.7 & 5.4 & 5.3 \\
\hline $\mathrm{MnO}_{2}$ & 0.1 & 0.1 & 0.1 \\
\hline $\mathrm{Na}_{2} \mathrm{O}$ & 4.9 & 5.2 & 5.5 \\
\hline $\mathrm{P}_{2} \mathrm{O}_{5}$ & 2.3 & 2.7 & 3.3 \\
\hline $\mathrm{SiO}_{2}$ & 47.6 & 46.1 & 46.9 \\
\hline Sro & 0.1 & 0.1 & 0.1 \\
\hline $\mathrm{TiO}_{2}$ & 4.1 & 4.2 & 4.2 \\
\hline $\mathrm{ZnO}$ & 0.2 & 0.2 & 0.3 \\
\hline $\mathrm{CeO}_{2}$ & - & 1.3 & - \\
\hline
\end{tabular}

(a) Oxidation state is assumed. 0xide composition is calculated from cation analysis and normalized to $100 \%$. 
TABLE 7. Waste Forms Produced for Phase Characterization and Leach Testing Composition

Pomona Basalt with 35 wt\% TBW-R

\begin{tabular}{|c|c|}
\hline $\mathrm{He}$ & ample Ident if \\
\hline $\begin{array}{l}\text { Melt } 2 \mathrm{~h} \text { at } 1300^{\circ} \mathrm{C} \\
\text { Anneal } 2 \mathrm{~h} \text { at } 550^{\circ} \mathrm{C}\end{array}$ & Parent Glass BG- \\
\hline
\end{tabular}

Nuc leate $0.5 \mathrm{~h}$ at $770^{\circ} \mathrm{C} \quad$ Glass Ceramic BGC-35-1 Crystallize $4 \mathrm{~h}$ at $950^{\circ} \mathrm{C}$

Nucleate $4 \mathrm{~h}$ at $700^{\circ} \mathrm{C}$

G]ass Ceramic BGC-35-2 Crystallize $8 \mathrm{~h}$ at $1050^{\circ} \mathrm{C}$

Pomona Basalt with 50 wt\% TBW-R

Melt $2 \mathrm{~h}$ at $1300^{\circ} \mathrm{C}$

Parent Glass BG-50

Anneal $2 \mathrm{~h}$ at $550^{\circ} \mathrm{C}$

Nuc leate $0.5 \mathrm{~h}$ at $700^{\circ} \mathrm{C}$ Crystallize $4 \mathrm{~h}$ at $950^{\circ} \mathrm{C}$

Glass Ceramic BGC-50

Reagent Chemicals with Melt $2 \mathrm{~h}$ at $1300^{\circ} \mathrm{C}$ Anneal $2 \mathrm{~h}$ at $550^{\circ} \mathrm{C}$

Parent Glass SBG-63 $63 \mathrm{wt} \%$ TBW-R

Nuc leate $0.5 \mathrm{~h}$ at $700^{\circ} \mathrm{C}$ Glass Ceramic SBGC-63 Crystallize $4 \mathrm{~h}$ at $1050^{\circ} \mathrm{C}$ 
TABLE 8. Crystal Morphologies Observed in Glass Ceramics

\begin{tabular}{|c|c|c|c|c|}
\hline $\begin{array}{l}\text { Crystal } \\
\text { Type }\end{array}$ & $B G C-35-1$ & $B G C-35-2$ & SBGE-63 & $B G C-50$ \\
\hline A & $\begin{array}{l}0.7 \mu \mathrm{m} \text { diameter } \\
\text { by } 0.2 \mu \mathrm{m} \text { thick } \\
\text { plates }\end{array}$ & $\begin{array}{l}\text { Blocks } \\
0.3 \text { to } 1.5 \mu \mathrm{m} \\
\text { sides }\end{array}$ & $\begin{array}{l}\text { B locks } \\
0.1 \text { to } 0.25 \mu \mathrm{m} \\
\text { sides }\end{array}$ & $\begin{array}{l}0.7 \mu \mathrm{m} \text { diameter } \\
\text { by } 0.2 \mu \mathrm{m} \\
\text { thick plates }\end{array}$ \\
\hline$B$ & $\begin{array}{l}0.05 \text { to } 0.15 \\
\mu \mathrm{m} \text { b locks }\end{array}$ & $\begin{array}{l}0.1 \text { to } 0.15 \mu \mathrm{m} \\
\text { blocks }\end{array}$ & $0.05 \mu \mathrm{m}$ blocks & $0.04 \mu \mathrm{m}$ blocks \\
\hline C & $\begin{array}{l}0.2 \text { um irregu- } \\
\text { lar blocks }\end{array}$ & $\begin{array}{l}1 \text { to } 3 \mu \mathrm{m} \\
\text { irregular }\end{array}$ & $\begin{array}{l}0.25 \text { um irregu- } \\
\text { lar blocks }\end{array}$ & $\begin{array}{l}0.04 \text { to } 0.13 \\
\text { irregular blocks }\end{array}$ \\
\hline D & $\begin{array}{l}0.1 \text { to } 0.15 \\
\text { irregular } \\
\text { blocks }\end{array}$ & $\begin{array}{l}0.15 \mu \mathrm{m} \\
\text { equiaxed }\end{array}$ & Not found & $0.1 \mu \mathrm{m}$ blocks \\
\hline$E$ & $\begin{array}{l}0.1 \text { to } 0.15 \mu \mathrm{m} \\
\text { irregular } \\
\text { blocks }\end{array}$ & Not found & $\begin{array}{l}1 \mu \mathrm{m} \text { by } 0.1 \mu \mathrm{m} \\
\text { elongated }\end{array}$ & $\begin{array}{l}0.01 \times 0.20 \mu \mathrm{m} \\
\text { elongated }\end{array}$ \\
\hline $\mathrm{F}$ & Not found & $\begin{array}{l}0.1 \times 1.5 \mu \mathrm{m} \\
\text { need les or } \\
\text { plates, } 0.1 \mu \mathrm{m} \\
\text { equiaxed }\end{array}$ & $\begin{array}{l}0.08 \mu \mathrm{m} \\
\text { equiaxed }\end{array}$ & Not found \\
\hline Frequency & $\begin{array}{l}\text { Mostly small } \\
B \text { and } C \\
\text { surrounding } \\
\text { type } A\end{array}$ & $\begin{array}{l}\text { Most ly large } \\
A \text { and } C \\
F \text { is cormon }\end{array}$ & $\begin{array}{l}\text { Most ly mixed } \\
A \text { and } C \\
E \text { and } F \text { rare }\end{array}$ & $\begin{array}{l}\text { Equal mix of } \\
B \text { and } C \\
\text { large } A\end{array}$ \\
\hline
\end{tabular}


TABLE 9. Glass-Ceramic Phase Compositions Determined by STEM (wt \% oxides) Type $A(a)$

\begin{tabular}{|c|c|c|c|c|}
\hline \multirow[b]{3}{*}{ 0xide } & \\
\hline & \multicolumn{4}{|c|}{ Sample ID (No. of Crystals Analyzed) } \\
\hline & $B G C-35-1(2)$ & $B G C-35-2(6)$ & SBGC-63 (6) & $B G C-50 \quad(5)$ \\
\hline $\mathrm{Fe}_{2} \mathrm{O}_{3}$ & $65-67$ & $72-74$ & $63-68$ & $65-67$ \\
\hline $\mathrm{TiO}_{2}$ & $23-26$ & $21-24$ & $17-20$ & $22-25$ \\
\hline $\mathrm{CaO}$ & $0.5-1.5$ & $0.5-1.5$ & 1.0 & $0.5-1.5$ \\
\hline $\mathrm{K}_{2} \mathrm{O}$ & $<0.5$ & $<0.5$ & $<0.5$ & $<0.5$ \\
\hline $\mathrm{P}_{2} \mathrm{O}_{5}$ & $<0.5$ & $<0.5$ & $<0.5$ & $<0.5$ \\
\hline $\mathrm{SiO}_{2}$ & 1.4 & $0.5-2$ & $1.5-8$ & $1-5$ \\
\hline $\mathrm{Al}_{2} \mathrm{O}_{3}$ & $1-2$ & $1.5-2$ & $4.5-6$ & $1-3$ \\
\hline $\mathrm{Mg}_{\mathrm{g}} \mathrm{O}$ & $2-3$ & $2-3.5$ & $2-3$ & $2-3$ \\
\hline \multirow[t]{3}{*}{$\mathrm{Na}_{2} \mathrm{O}$} & $1-2$ & $<0.5$ & $\cdot 2-4$ & $1-3$ \\
\hline & \multicolumn{4}{|c|}{ Type $B(b)$} \\
\hline & \multicolumn{4}{|c|}{ Sample ID (No. Of Crystals Analyzed) } \\
\hline$\underline{\text { Oxide }}$ & $B G C-35-1 \quad(4)$ & $B G C-35-2(2)$ & SBGC-63(6) & $B G C-50(6)$ \\
\hline $\mathrm{Fe}_{2} \mathrm{O}_{3}$ & $30-50$ & $42-48$ & $26-36$ & $28-50$ \\
\hline $\mathrm{TiO}_{2}$ & $3-5$ & 3 & $4-9$ & $3-13$ \\
\hline $\mathrm{CaO}^{2}$ & $2-5.5$ & $1-1.5$ & $2-9$ & $2-6$ \\
\hline $\mathrm{K}_{2} \mathrm{O}$ & $0-0.5$ & $<0.5$ & $1-1.5$ & $0.5-1$ \\
\hline $\mathrm{P}_{2} \mathrm{O}_{5}$ & $<0.5$ & $<0.5$ & $0-1$ & $0.5-4$ \\
\hline $\mathrm{SiO}_{2}$ & $23-45$ & $25-36$ & $33-42$ & $18-38$ \\
\hline $\mathrm{Al}_{2} \mathrm{O}_{3}$ & $8-14$ & $13-14$ & $6.5-9.5$ & $9-12$ \\
\hline $\mathrm{MgO}$ & $3-6.5$ & $3.5-7$ & $1-6.5$ & $5-8$ \\
\hline $\mathrm{Na}_{2} \mathrm{O}$ & $1-5$ & $1-2$ & $4-10$ & $4-5.5$ \\
\hline
\end{tabular}

(a) Type $A=\mathrm{Fe}_{2}-3 \mathrm{TiO} x+\mathrm{Mg}, \mathrm{Al}$; Titaniferous Hematite.

(b) Type $B=F e A i M g N a C a$ Silicate; Clinopyroxene, probably fassaite. 
TABLE 9. (contd)

Type C(a)

Sample ID (No. of Crystals Analyzed)

Oxide BGC-35-1 (5) BGC-35-2(6) SBGC-63(4) BGC-50 (8)

$\begin{array}{lllcc}\mathrm{Fe}_{2} \mathrm{O}_{3} & 5.5-12.5 & 9.14 & 12-16 & 9-10 \\ \mathrm{TiO}_{2} & 1-3 & 1-2.5 & 1-6 & 2-4 \\ \mathrm{CaO} & 5-11.5 & 12-19 & 9.5-12 & 16-18 \\ \mathrm{~K}_{2} \mathrm{O} & 0-1 & <0.5 & 0-0.5 & <0.5 \\ \mathrm{P}_{2} \mathrm{O}_{5} & 0-2.5 & <0.5 & 0-4 & 0.5-1.5 \\ \mathrm{SiO}_{2} & 44-68 & 48-63 & 43-55 & 44-49 \\ \mathrm{Al}_{2} \mathrm{O}_{3} & 8-12.5 & 2-5.5 & 4-10 & 7-8 \\ \mathrm{MgO} \mathrm{B} & 4-10 & 9-18 & 9-13 & 13-14.5 \\ \mathrm{Na}_{2} \mathrm{O} & 1-4 & 0.5-1 & 1-3 & 1-3\end{array}$

Type D(b)

Sample ID (No. of Crystals Analyzed)

Oxide $B G C-35-1(2) \quad B G C-35-2(2) \quad S B G C-63 \quad B G C-50$ (2)

$\mathrm{Fe}_{2} \mathrm{O}_{3} \quad 63-66 \quad 62-68 \quad 76$

$\mathrm{TiO}_{2} 4.5-6 \quad 4.5-5 \quad 2-14$

$\mathrm{CaO} \quad 1-1.5 \quad 1.5-2.5 \quad 0.5-1.5$

$\begin{array}{lllll}\mathrm{K}_{2} \mathrm{O} & 0-0.5 & <0.5 & \text { Not } & <0.5\end{array}$

$\begin{array}{lllll}\mathrm{P}_{2} \mathrm{O}_{5} & <0.5 & 0-2 & \text { Found } & 0.1\end{array}$

$\mathrm{SiO}_{2} \quad 9-12.5 \quad 8-13 \quad 1$

$\mathrm{Al}_{2} \mathrm{O}_{3} \quad 10-10.5 \quad 1-2.5 \quad 2-6.5$

$\begin{array}{llll}\mathrm{MgO} & 4.5 & 5-5.5 & 3.5-9.5\end{array}$

$\mathrm{Na}_{2} \mathrm{O} \quad 1.5-4 \quad 0-1 \quad 0.5-3$

(a) Type $C=C$ aMgAlFe Silicate; Augite.

(b) Type $\mathrm{D}=\mathrm{Fe}_{2} \mathrm{O}_{3}+\mathrm{Ti}, \mathrm{Mg}, \mathrm{Al}$, Si; Magnet ite 
TABLE 9. (contd)

\begin{tabular}{|c|c|c|c|c|}
\hline \multirow[b]{3}{*}{ Oxide } & \multicolumn{4}{|c|}{ Type $E(a)$} \\
\hline & \multicolumn{4}{|c|}{ Sample ID (No. of Crystals Analyzed) } \\
\hline & $\mathrm{BGC}-35-1(2)$ & $\mathrm{BGC}-35-2$ & SBGC-63(1) & $\mathrm{BGC}-50(2)$ \\
\hline $\mathrm{Fe}_{2} \mathrm{O}_{3}$ & $24-60$ & & 47 & $43-52$ \\
\hline $\mathrm{TiO}_{2}$ & $26-40$ & & 45 & $15-17$ \\
\hline $\mathrm{CaO}$ & $2-4.5$ & & 1 & $1-5.5$ \\
\hline $\mathrm{K}_{2} \mathrm{O}$ & $<0.5$ & Not & $<0.5$ & $0-0.5$ \\
\hline $\mathrm{P}_{2} \mathrm{O}_{5}$ & $0-0.5$ & Found & $<0.5$ & $<0.5$ \\
\hline $\mathrm{SiO}_{2}$ & $9-30$ & & 3.5 & $7-15$ \\
\hline $\mathrm{Al}_{2} \mathrm{O}_{3}$ & $7-8$ & & 1 & $8-9$ \\
\hline $\mathrm{MgO}$ & $4-5-5$ & & 2.5 & $8-9$ \\
\hline $\mathrm{Na}_{2} \mathrm{O}$ & $1-1.5$ & & $<0.5$ & 4 \\
\hline
\end{tabular}

Type $F \quad$ (b)

Sample ID (No. of Crystals Analyzed)

$\underline{\text { Oxid }}$

$\mathrm{Fe}_{2} \mathrm{O}_{3}$

$\mathrm{TiO}_{2}$

$\mathrm{CaO}$

\begin{tabular}{|c|c|c|c|}
\hline$B G C-35-1$ & $B G C-35-2(1)$ & SBGC-63(1) & $B G C-50$ \\
\hline & $2-4$ & 8 & \\
\hline
\end{tabular}

$\mathrm{K}_{2} \mathrm{O}$

$\mathrm{P}_{2} \mathrm{O}_{5}$

$\mathrm{SiO}_{2}$

$\mathrm{Al}_{2} \mathrm{O}_{3}$

$\mathrm{MgO}$

$\mathrm{Na}_{2} \mathrm{O}$

$\begin{array}{ccc} & 24-32 & 17 \\ \text { Not } & <0.5 & 1 \\ \text { Found } & 22-33 & 20 \\ & 27-40 & 40 \\ & 7-9 & 7 \\ & 1-3 & 4 \\ & 0-1 & 3.5\end{array}$

(a) Type $\mathrm{E}=\mathrm{FeTiO}+\mathrm{Si}, \mathrm{Al}, \mathrm{Mg}$.

(b) Type $\mathrm{F}=\mathrm{Ca}, \mathrm{P}$ Silicate $+\mathrm{Al}, \mathrm{Fe}$; Apatite 
TABLE 10. Identification of Pyroxene Crystals in BGC-50 by Selected Area Diffraction Ring Patterns

\begin{tabular}{|c|c|c|c|c|c|c|}
\hline \multirow[b]{2}{*}{ No. } & \multicolumn{2}{|c|}{$\begin{array}{l}\text { Diffraction Patterns } \\
\text { From } B G C-50\end{array}$} & \multicolumn{2}{|c|}{$\begin{array}{c}\text { ASTM } 25-206 A \\
\text { Fassaite }(a)\end{array}$} & \multicolumn{2}{|c|}{$\begin{array}{l}\text { ASTM 17-522 } \\
\text { Omphacite(b) }\end{array}$} \\
\hline & $d(n m)$ & No. of Spots & $\mathrm{d}(\mathrm{nm})$ & hk l & $\mathrm{d}(\mathrm{nm})$ & hk 7 \\
\hline 1 & 0.643 & $>20$ & 0.646 & 110 & 0.64 & 110 \\
\hline 2 & 0.473 & $>20$ & 0.471 & 200 & & \\
\hline 3 & 0.466 & $<10$ & & & & \\
\hline 4 & 0.444 & $<10$ & 0.443 & 020 & 0.44 & 020 \\
\hline 5 & 0.384 & $<10$ & & & 0.38 & \\
\hline 6 & 0.334 & $<10$ & & & 0.333 & 021 \\
\hline 7 & 0.321 & $>50$ & 0.323 & 220 & 0.319 & 220 \\
\hline 8 & 0.301 & $>10$ & 0.300 & 221 & & \\
\hline 9 & 0.298 & $>100$ & 0.297 & 310 & 0.298 & 221 \\
\hline 10 & 0.292 & $>100$ & 0.290 & 311 & 0.292 & 310 \\
\hline 11 & 0.287 & $>50$ & & & 0.288 & 311 \\
\hline 12 & 0.281 & $>20$ & & & & \\
\hline 13 & 0.260 & $>20$ & 0.258 & 002 & & \\
\hline 14 & 0.256 & $>100$ & 0.256 & 131 & 0.255 & 131 \\
\hline 15 & 0.253 & $>20$ & 0.253 & 221 & 0.252 & 202 \\
\hline 16 & 0.249 & $>20$ & & & 0.248 & 221 \\
\hline
\end{tabular}

(a) Fassaite: $\mathrm{Ca}_{1.0} \mathrm{Ti}_{0.48} \mathrm{Mg}_{0} .39 \mathrm{Al}_{0} .13\left(\mathrm{Si}_{1.26} \mathrm{Al}_{0.74}\right) 0_{6}$

(b) Omphacite:

$\mathrm{Na} 0.325\left(\mathrm{Ca} 0.583 \mathrm{Fe}_{0.116} \mathrm{Mg} 0.528\right) 1.283\left(\mathrm{Fe} .123 \mathrm{Al}_{0} .238\right)_{3.36} \mathrm{Si}_{1} .973 \mathrm{O}_{6}$ 
TABLE 11. Residual Glass Phase Compositions (Wt\% oxide)(a)

\begin{tabular}{lcccc} 
& \multicolumn{5}{c}{ Sample ID (No. of Regions Analyzed) } \\
\cline { 3 - 5 }$\frac{\text { Oxide }}{\mathrm{Fe}_{2} \mathrm{O}_{3}}$ & $\frac{B G C-35-1(5)}{4-13}$ & $\frac{B G C-35-2(6)}{1.5-8.5}$ & $\frac{S B G C-63(5)}{4-11}$ & $\frac{B G C-50(13)}{5-14}$ \\
$\mathrm{TiO}_{2}$ & $1-6$ & $0.5-1$ & $1-1.5$ & $2-5$ \\
$\mathrm{CaO}$ & $2-10$ & $1-3.5$ & 3.7 & $3.5-8$ \\
$\mathrm{~K}_{2} \mathrm{O}$ & $0.5-2$ & $<0.5-3$ & $0.5-3$ & $0.5-3$ \\
$\mathrm{P}_{2} \mathrm{O}_{5}$ & $0-5$ & $<0.5$ & $0-3$ & $0-4.5$ \\
$\mathrm{SiO}_{2}$ & $44-81$ & $66-85$ & $49-82$ & $55-60$ \\
$\mathrm{Al}_{2} \mathrm{O}_{3}$ & $9-14$ & $11-18$ & $9-12$ & $11-14$ \\
$\mathrm{MgO}$ & $1-4$ & $0.5-1$ & $1-2.5$ & $2-3.5$ \\
$\mathrm{Na}_{2} \mathrm{O}$ & $1-23$ (b) & $<0.5$ & $1-11$ & $3.5-15$ \\
\end{tabular}

(a) Matrix $=\mathrm{Al}, \mathrm{Fe}, \mathrm{Ca}$ Silicate; highly variable Na.

(b) Excessively high $\mathrm{Na}$ from very thin specimen regions.

TABLE 12. Crystalline Phase Yield in Glass Ceramics Determined by XRD Crystallinity, wt\%

\begin{tabular}{|c|c|c|c|c|c|}
\hline Material & Hematite & Augite & Spine 1 & Unknown & Total \\
\hline$B G C-35-1$ & 15 & 20 & Trace & Trace & 35 \\
\hline$B G C-35-2$ & 25 & 20 & Trace & Trace & 45 \\
\hline$B G C-50$ & 15 & 20 & Trace & Trace & 35 \\
\hline SBGC-63 & 5 & 20 & 10 & Trace & 35 \\
\hline
\end{tabular}


TABLE 13. Normalized Elemental Mass Losses for Static MCC-1 Leach Test, $90^{\circ} \mathrm{C}$, D.I. Water, $S A / \mathrm{V}=10 \mathrm{~m}^{-1}$

\begin{tabular}{|c|c|c|c|c|c|c|c|c|}
\hline \multirow[b]{2}{*}{ Material } & \multirow{2}{*}{$\begin{array}{l}\text { Leaching } \\
\text { Time, d }\end{array}$} & \multicolumn{7}{|c|}{ Normalized Elemental Mass Loss, $\mathrm{g} / \mathrm{m}^{2}$} \\
\hline & & A1 & $\mathrm{Fe}$ & $\mathrm{Ca}$ & $\mathrm{Mg}$ & $\mathrm{Na}$ & $\mathrm{Si}$ & $\mathrm{pH}$ \\
\hline$B G-35$ & $\begin{array}{c}7 \\
14 \\
28 \\
\sigma(a)\end{array}$ & $\begin{array}{r}4.25 \\
4.47 \\
4.52 \\
\pm 0.03\end{array}$ & $\begin{array}{c}0.01 \\
0.01 \\
0.01 \\
-\end{array}$ & $\begin{array}{r}3.85 \\
4.51 \\
4.97 \\
\pm 0.11\end{array}$ & $\begin{array}{r}3.50 \\
2.70 \\
2.91 \\
\pm 0.24\end{array}$ & $\begin{array}{r}4.35 \\
5.48 \\
6.30 \\
\pm 0.30\end{array}$ & $\begin{array}{r}4.85 \\
6.10 \\
6.56 \\
\pm 0.09\end{array}$ & $\begin{array}{r}8.05 \\
9.05 \\
8.22 \\
\pm 0.13\end{array}$ \\
\hline$B G C-35$ & $\begin{array}{c}3 \\
7 \\
14 \\
28 \\
\sigma(a) \\
49 \\
67 \\
93\end{array}$ & $\begin{array}{r}0.10 \\
0.19 \\
0.18 \\
1.09 \\
\pm 0.04 \\
2.11 \\
2.46 \\
3.62\end{array}$ & $\begin{array}{c}0.03 \\
0.05 \\
0.06 \\
0.05 \\
- \\
0.04 \\
0.05 \\
0.13\end{array}$ & $\begin{array}{r}0.20 \\
0.28 \\
0.30 \\
0.99 \\
\pm 0.06 \\
1.32 \\
1.44 \\
1.81\end{array}$ & $\begin{array}{c}-(b) \\
- \\
0.17 \\
0.86 \\
\pm 0.07 \\
1.17 \\
1.21 \\
1.50\end{array}$ & $\begin{array}{r}0.39 \\
0.55 \\
0.64 \\
1.32 \\
\pm 0.08 \\
2.66 \\
2.66 \\
4.12\end{array}$ & $\begin{array}{r}0.13 \\
0.27 \\
0.38 \\
1.39 \\
\pm 0.04 \\
2.74 \\
2.69 \\
3.69\end{array}$ & $\begin{array}{r}5.60 \\
5.54 \\
6.04 \\
7.07 \\
\pm 0.03 \\
8.10 \\
8.02 \\
8.32\end{array}$ \\
\hline$B G C-35$ & $\begin{array}{l}3 \\
7 \\
14 \\
28 \\
\sigma(a) \\
49 \\
67 \\
93\end{array}$ & $\begin{array}{r}0.13 \\
0.23 \\
0.23 \\
1.14 \\
\pm 0.13 \\
1.95 \\
3.83 \\
3.24\end{array}$ & $\begin{array}{c}0.01 \\
0.02 \\
0.02 \\
0.04 \\
- \\
0.04 \\
0.12 \\
0.10\end{array}$ & $\begin{array}{r}0.16 \\
0.29 \\
0.26 \\
0.74 \\
\pm 0.05 \\
1.16 \\
1.74 \\
1.81\end{array}$ & $\begin{array}{c}- \\
- \\
0.10 \\
0.40 \\
\pm 0.02 \\
0.62 \\
1.01 \\
0.97\end{array}$ & $\begin{array}{r}0.25 \\
0.47 \\
0.53 \\
1.32 \\
\pm 0.14 \\
2.64 \\
3.27 \\
4.45\end{array}$ & $\begin{array}{r}0.16 \\
0.31 \\
0.39 \\
1.51 \\
\pm 0.15 \\
3.02 \\
3.77 \\
4.34\end{array}$ & $\begin{array}{r}5.41 \\
5.76 \\
6.27 \\
7.69 \\
\pm 0.12 \\
8.01 \\
8.10 \\
8.09\end{array}$ \\
\hline$B G-50$ & $\begin{array}{l}7 \\
14 \\
28 \\
\sigma(a) \\
41 \\
49 \\
56\end{array}$ & $\begin{array}{r}4.59 \\
4.94 \\
5.05 \\
\pm 0.08 \\
8.56 \\
5.24 \\
6.91\end{array}$ & $\begin{array}{c}0.01 \\
0.01 \\
0.02 \\
- \\
0.40 \\
0.27 \\
0.23\end{array}$ & $\begin{array}{r}3.97 \\
4.97 \\
5.13 \\
\pm 0.19 \\
6.96 \\
6.42 \\
6.79\end{array}$ & $\begin{array}{r}4.15 \\
3.52 \\
3.65 \\
\pm 0.07 \\
7.83 \\
4.43 \\
5.63\end{array}$ & $\begin{array}{r}4.21 \\
4.99 \\
5.78 \\
\pm 0.27 \\
8.35 \\
6.90 \\
7.80\end{array}$ & $\begin{array}{r}5.24 \\
6.54 \\
7.08 \\
\pm 0.11 \\
9.82 \\
8.57 \\
8.99\end{array}$ & $\begin{array}{r}7.97 \\
9.26 \\
8.47 \\
\pm 0.15 \\
8.75 \\
8.32 \\
7.94\end{array}$ \\
\hline$B G C-50$ & $\begin{array}{l}3 \\
7 \\
14 \\
28 \\
6(a) \\
49 \\
67 \\
93\end{array}$ & $\begin{array}{r}0.11 \\
0.15 \\
0.20 \\
0.54 \\
\pm 0.16 \\
1.14 \\
2.00 \\
2.49\end{array}$ & $\begin{array}{c}0.01 \\
0.01 \\
0.01 \\
0.01 \\
- \\
0.08 \\
0.10 \\
0.11\end{array}$ & $\begin{array}{r}0.12 \\
0.23 \\
0.18 \\
0.43 \\
\pm 0.11 \\
0.63 \\
0.91 \\
0.93\end{array}$ & $\begin{array}{c}- \\
- \\
0.12 \\
0.36 \\
\pm 0.12 \\
0.59 \\
0.78 \\
0.80\end{array}$ & $\begin{array}{r}0.44 \\
0.70 \\
0.73 \\
1.29 \\
\pm 0.07 \\
1.83 \\
2.30 \\
3.02\end{array}$ & $\begin{array}{r}0.16 \\
0.27 \\
0.35 \\
0.84 \\
\pm 0.18 \\
1.89 \\
2.53 \\
2.98\end{array}$ & $\begin{array}{r}5.45 \\
5.64 \\
6.19 \\
7.16 \\
\pm 0.36 \\
7.90 \\
7.71 \\
8.11\end{array}$ \\
\hline
\end{tabular}


TABLE 13. (contd)

\begin{tabular}{|c|c|c|c|c|c|c|c|c|}
\hline \multirow[b]{2}{*}{ Material } & \multirow{2}{*}{$\begin{array}{l}\text { Leaching } \\
\text { Time, d }\end{array}$} & \multicolumn{7}{|c|}{ Normalized Elemental Mass Loss, $\mathrm{g} / \mathrm{m}^{2}$} \\
\hline & & $A 1$ & $\mathrm{Fe}$ & $\mathrm{Ca}$ & $\mathrm{Mg}$ & $\mathrm{Na}$ & Si & $\mathrm{pH}$ \\
\hline SBG-63 & $\begin{array}{c}7 \\
14 \\
28 \\
0\end{array}$ & $\begin{array}{r}4.39 \\
4.41 \\
8.64 \\
\pm 0.01\end{array}$ & $\begin{array}{l}- \\
0.01 \\
0.01 \\
-\end{array}$ & $\begin{array}{r}3.56 \\
3.85 \\
4.03 \\
\pm 0.03\end{array}$ & $\begin{array}{r}3.21 \\
2.83 \\
2.63 \\
\pm 0.24\end{array}$ & $\begin{array}{r}5.67 \\
6.68 \\
8.02 \\
\pm 0.26\end{array}$ & $\begin{array}{r}5.75 \\
6.52 \\
7.18 \\
\pm 0.08\end{array}$ & $\begin{array}{r}7.91 \\
9.14 \\
8.64 \\
\pm 0.01\end{array}$ \\
\hline$G C-63$ & $\begin{array}{l}3 \\
7 \\
14 \\
28 \\
0(a) \\
49 \\
67 \\
93\end{array}$ & $\begin{array}{r}0.09 \\
0.13 \\
0.29 \\
0.85 \\
\pm 0.16 \\
2.08 \\
2.88 \\
2.04\end{array}$ & $\begin{array}{l}0.02 \\
0.04 \\
0.07 \\
0.02 \\
- \\
0.06 \\
0.11 \\
0.06\end{array}$ & $\begin{array}{r}0.19 \\
0.28 \\
0.37 \\
0.53 \\
\pm 0.12 \\
0.89 \\
1.07 \\
0.97\end{array}$ & $\begin{array}{c}- \\
- \\
0.19 \\
0.38 \\
\pm 0.17 \\
1.06 \\
1.10 \\
0.87\end{array}$ & $\begin{array}{r}0.49 \\
0.74 \\
0.88 \\
1.42 \\
\pm 0.05 \\
2.70 \\
3.12 \\
3.54\end{array}$ & $\begin{array}{r}0.15 \\
0.26 \\
0.43 \\
1.04 \\
\pm 0.19 \\
2.73 \\
3.06 \\
2.95\end{array}$ & $\begin{array}{r}5.66 \\
5.77 \\
6.49 \\
7.41 \\
\pm 0.35 \\
8.05 \\
7.79 \\
7.90\end{array}$ \\
\hline
\end{tabular}

(a) Standard deviations calculated from three tests at 28 days. 
TABLE 14. Estimates of Glass Matrix Composition (wt\%)

\begin{tabular}{|c|c|c|c|c|}
\hline Oxide & $A(a)$ & $B(b)$ & $c(c)$ & $D(d)$ \\
\hline $\mathrm{SiO}_{2}$ & 46 & - & 54 & 55 \\
\hline $\mathrm{Al}_{2} \mathrm{O}_{3}$ & 12 & - & 12 & 12 \\
\hline $\mathrm{Fe}_{2} \mathrm{O}_{3}$ & 15 & 73 & 4 & 9 \\
\hline $\mathrm{TiO}_{2}$ & 4 & 27 & - & 3 \\
\hline $\mathrm{CaO}$ & 9 & - & 11 & 5.5 \\
\hline $\mathrm{MgO}$ & 5 & - & 6 & 2.5 \\
\hline $\mathrm{Na}_{2} \mathrm{O}$ & 5 & - & 6 & 9 \\
\hline $\mathrm{P}_{2} \mathrm{O}_{5}$ & 3 & - & 3.5 & 2 \\
\hline Others & 3 & $=$ & 3.5 & 2 \\
\hline TOTAL & 100 & 100 & 100 & 100 \\
\hline
\end{tabular}
(a) Bulk material from Table 6.
(b) Simplified Average Titaniferrous Hematite from Table 7.
(c) Estimated BG-50 Parent Glass Composition determined by Column A - $15 \%$ of Column B divided by $85 \%$.
(d) Average Residual Glass Matrix in $B G C-50$ determined by TEM/EDX (Table 11).

TABLE 15. Comparison of Leachability Basalt Glass Ceramic with Other TRU Nuclear Waste Forms Containing 239pu(a). MCC-1 Stat ic Leach Test, $90^{\circ} \mathrm{C}$, D.I. Water, $S A / \mathrm{V}=10 \mathrm{~m}^{-1}, 28$ Days

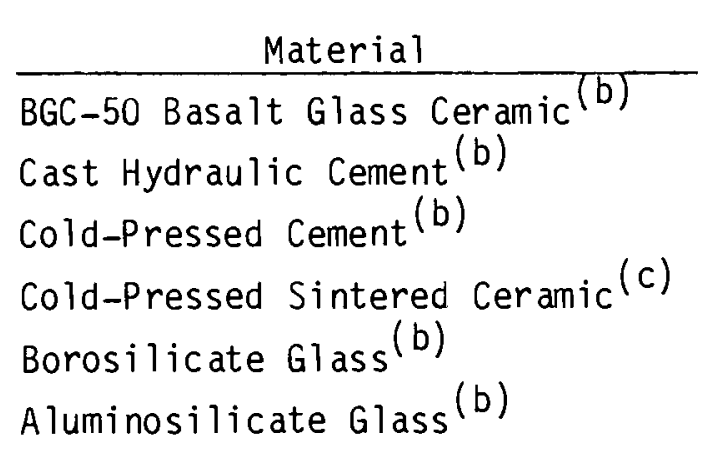

\begin{tabular}{|c|c|c|c|c|c|c|}
\hline Al & $\mathrm{Fe}$ & $\mathrm{Ca}$ & $\frac{\mathrm{enta}}{\mathrm{Na}}$ & $\begin{array}{l}\text { Mass } \\
\text { i }\end{array}$ & $\frac{\mathrm{OSS},}{\mathrm{Pu}}$ & $\mathrm{pH}$ \\
\hline 0.16 & 0.05 & 0.24 & 0.04 & 0.13 & 0.02 & 4.2 \\
\hline 24 & 0.07 & 98 & 990 & 1.6 & 0.0005 & 11.4 \\
\hline 12 & 0.08 & 74 & 1300 & 3.4 & 0.002 & 11.3 \\
\hline 0.27 & 0.13 & 26 & 1.7 & 0.21 & 0.006 & 4.6 \\
\hline$<$ & $<$ & 0.28 & $<$ & 0.36 & 0.03 & 5.0 \\
\hline 0.06 & 0.29 & 1.1 & 0.69 & 0.48 & 0.003 & 5.4 \\
\hline
\end{tabular}

(a) Data from Chikalla and Powell 1981.

(b) Average of three test results.

(c) Average of two test results.

(d) Element concentration below detection limit in leach solution. 


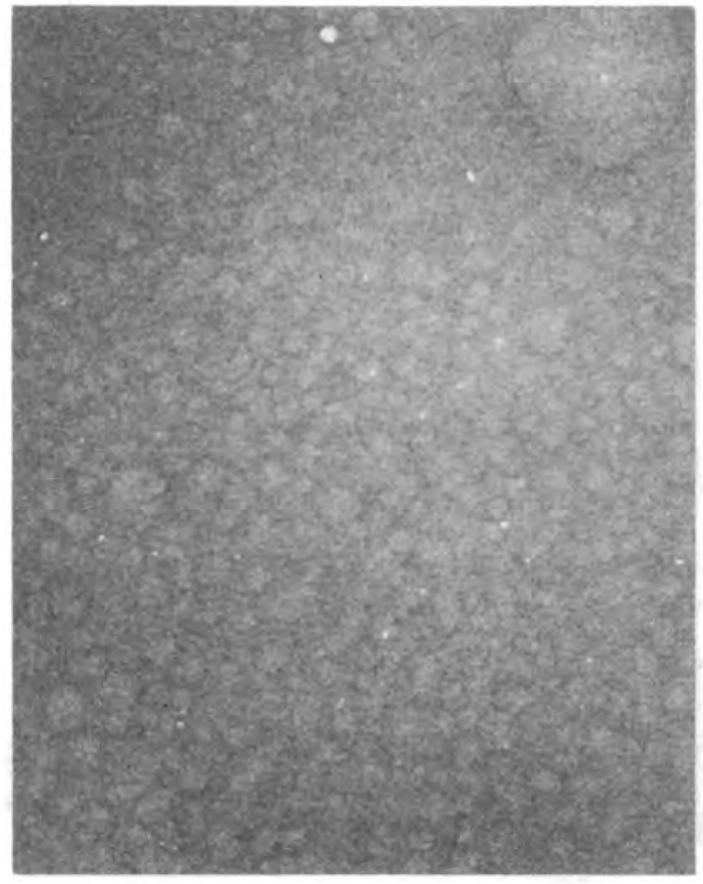

GLASS ANNEALED $550^{\circ} \mathrm{C}-2 \mathrm{~h}$

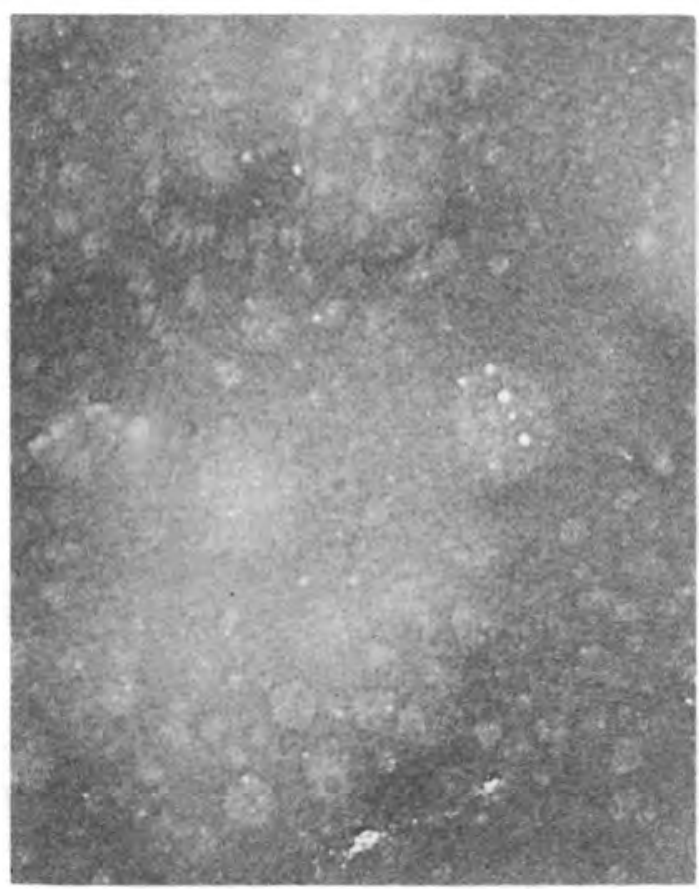

$700^{\circ} \mathrm{C}-2 \mathrm{~h}$

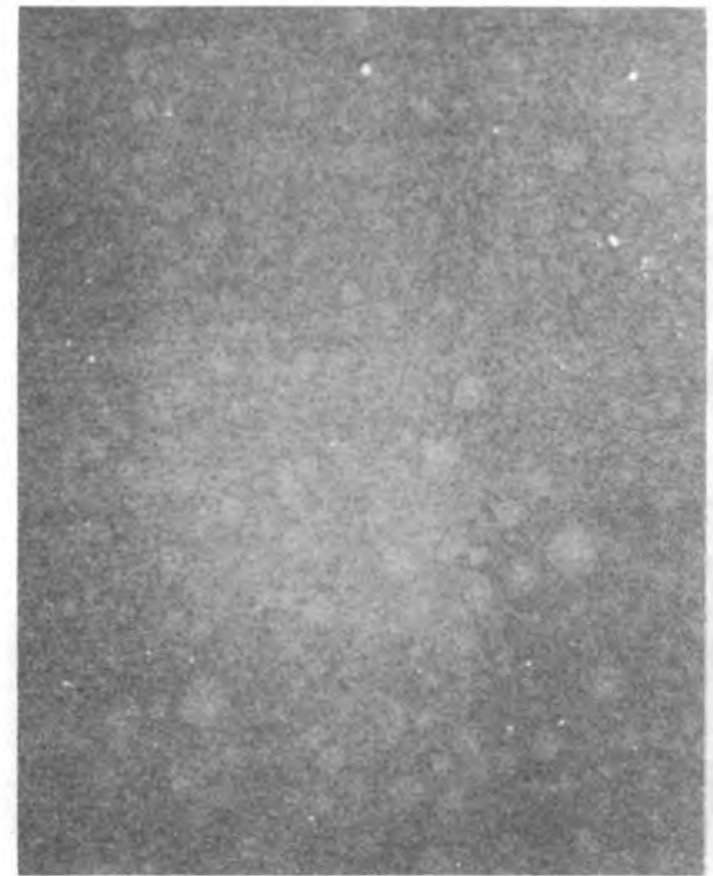

$700^{\circ} \mathrm{C}-0.5 \mathrm{~h}$

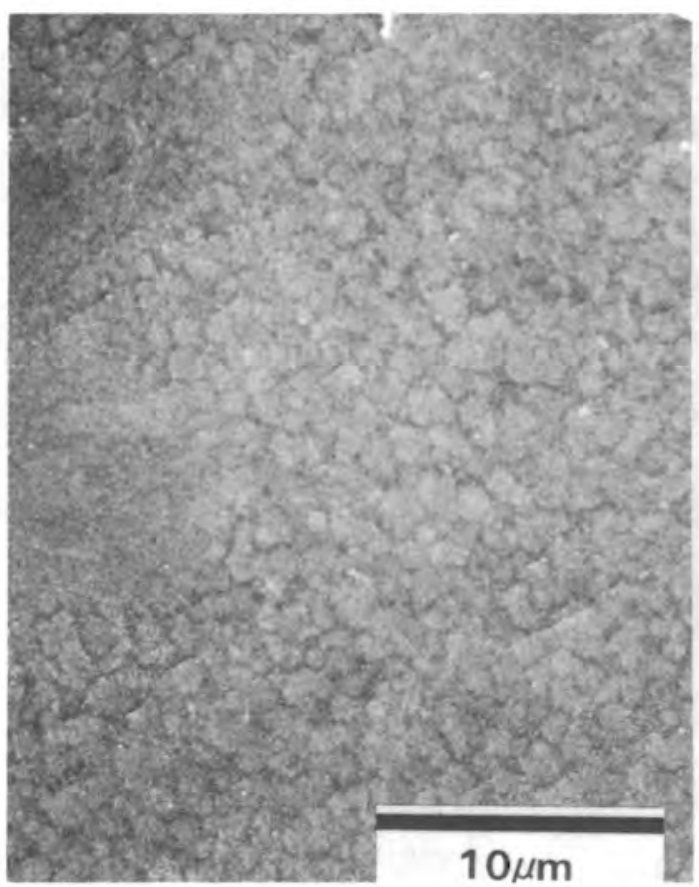

$700^{\circ} \mathrm{C}-6 \mathrm{~h}$

FIGURE 1. SEM Fractographs Showing Effect of Nucleation Time on Microstructure of Basalt Glass Containing 50 wt\% TBW-R 


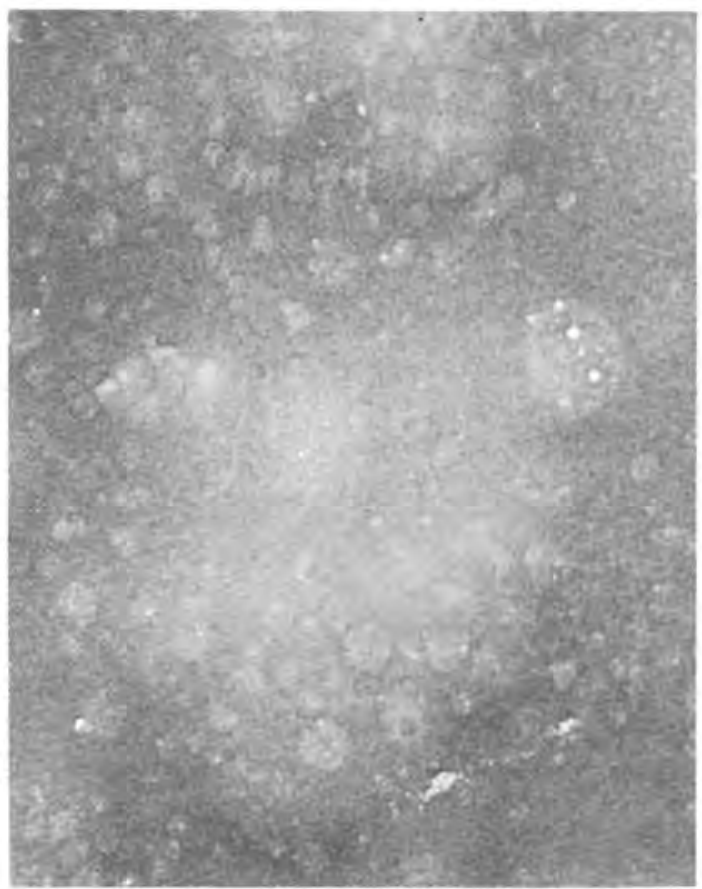

$700^{\circ} \mathrm{C}-2 \mathrm{~h}$

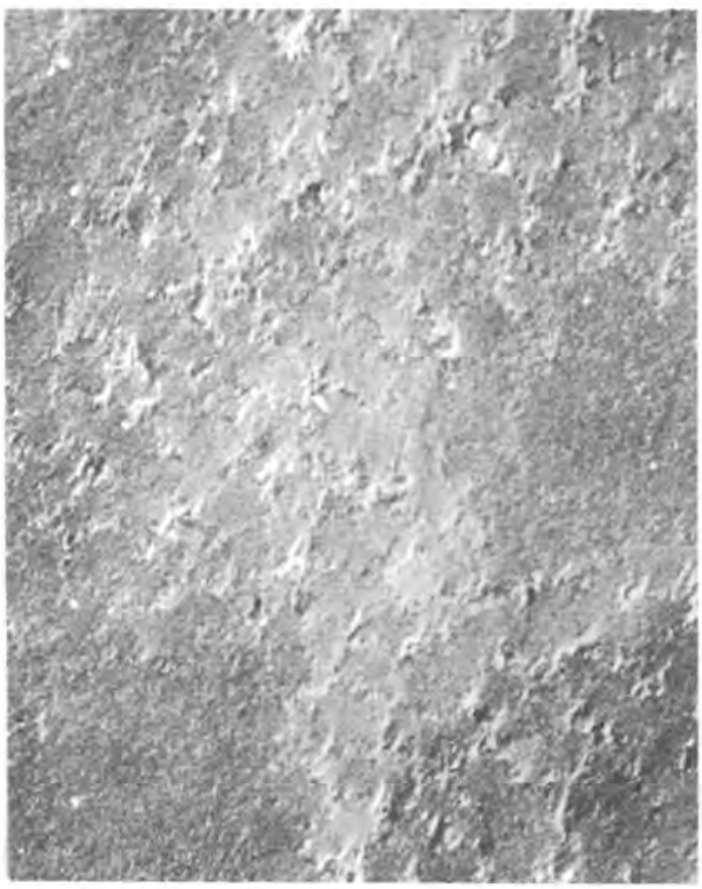

$800^{\circ} \mathrm{C}-2 \mathrm{~h}$

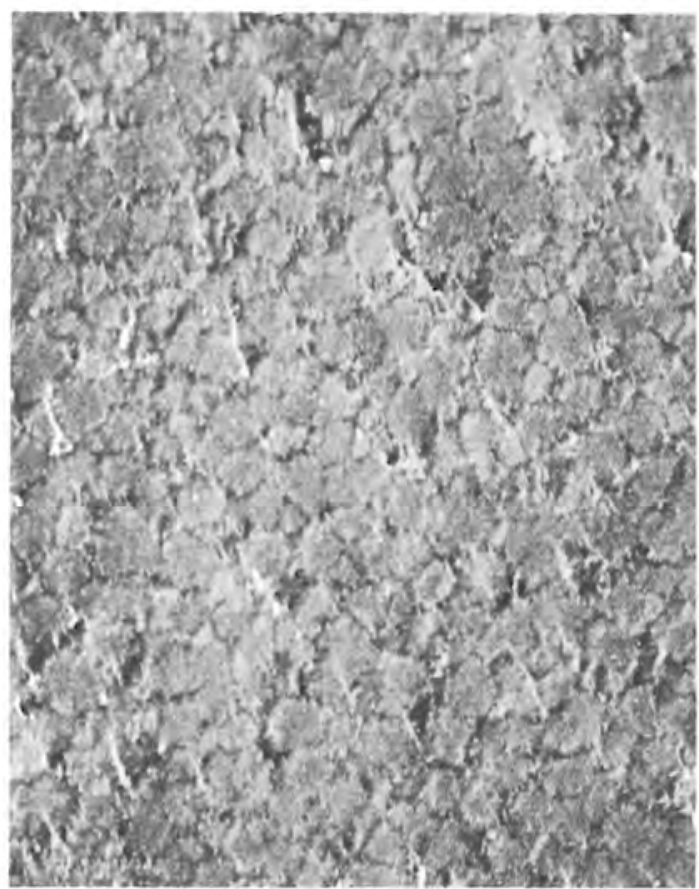

$750^{\circ} \mathrm{C}-2 \mathrm{~h}$

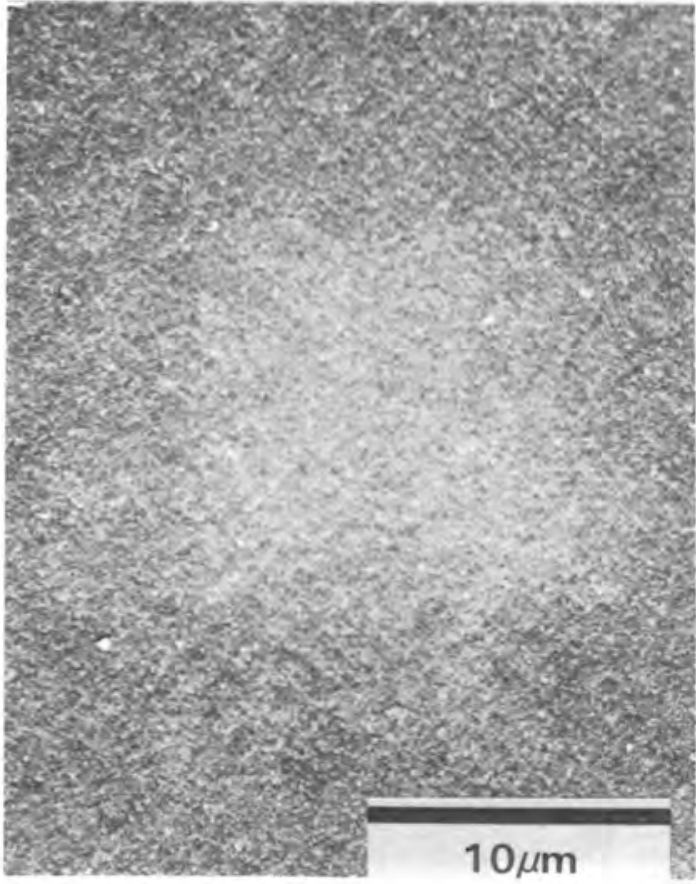

$850^{\circ} \mathrm{C}-2 \mathrm{~h}$

FIGURE 2. SEM Fractographs Showing Effect of Nucleation Temperature on Microstructure of Basalt Glass Containing 50 wt\% TBW-R 

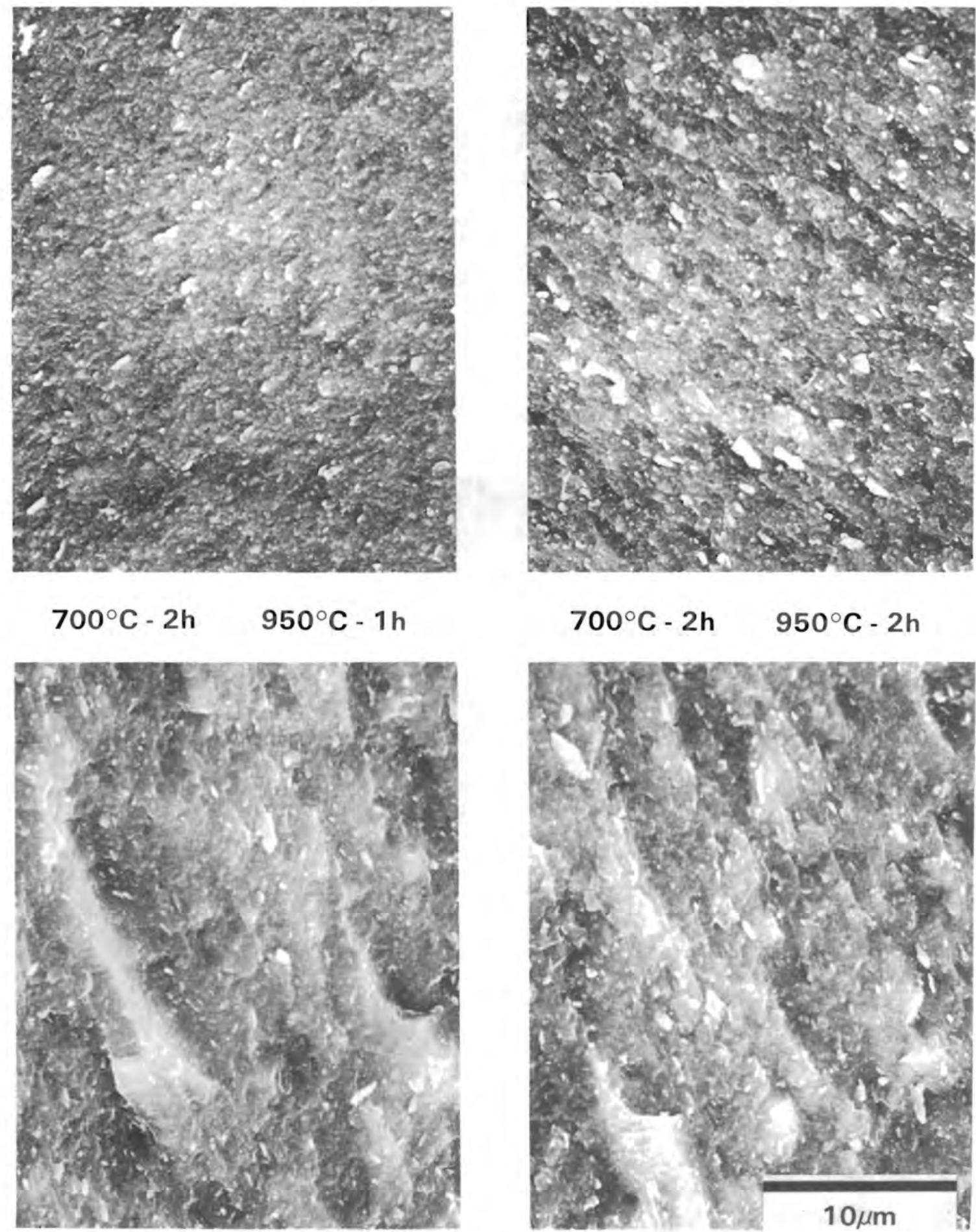

$700^{\circ} \mathrm{C}-2 \mathrm{~h} \quad 950^{\circ} \mathrm{C}-4 \mathrm{~h}$

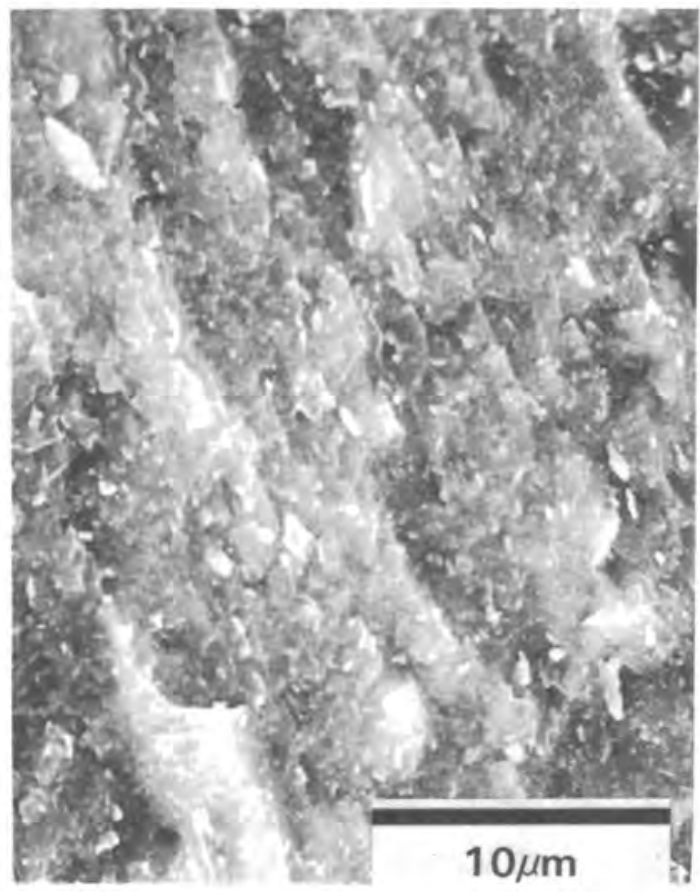

$700^{\circ} \mathrm{C}-2 \mathrm{~h} \quad 950^{\circ} \mathrm{C}-8 \mathrm{~h}$

FIGURE 3. SEM Fractographs Showing Effect of Cyrstallization Time on Microstructure of Basalt Glass Containing 50 wt\% TBW-R 


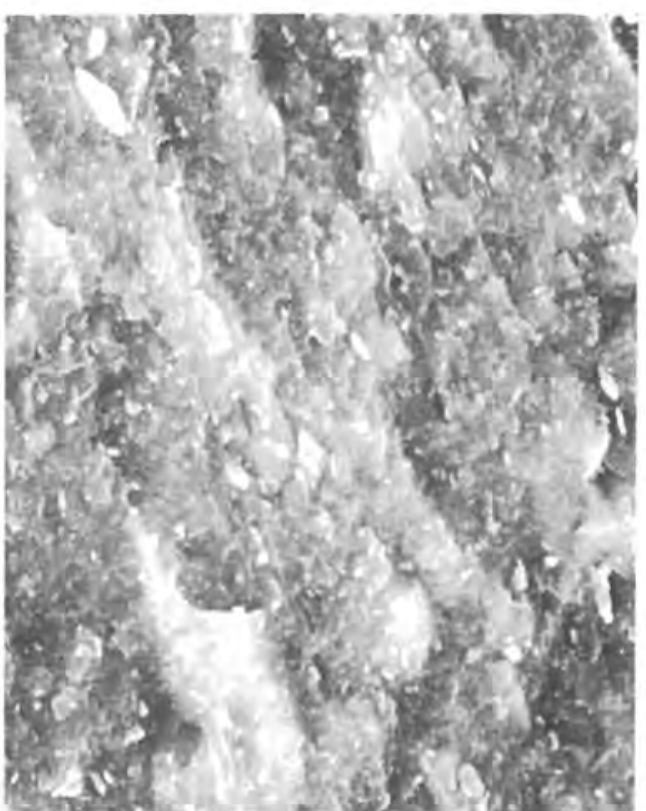

$700^{\circ} \mathrm{C}-2 \mathrm{~h}$

$950^{\circ} \mathrm{C}-8 \mathrm{~h}$

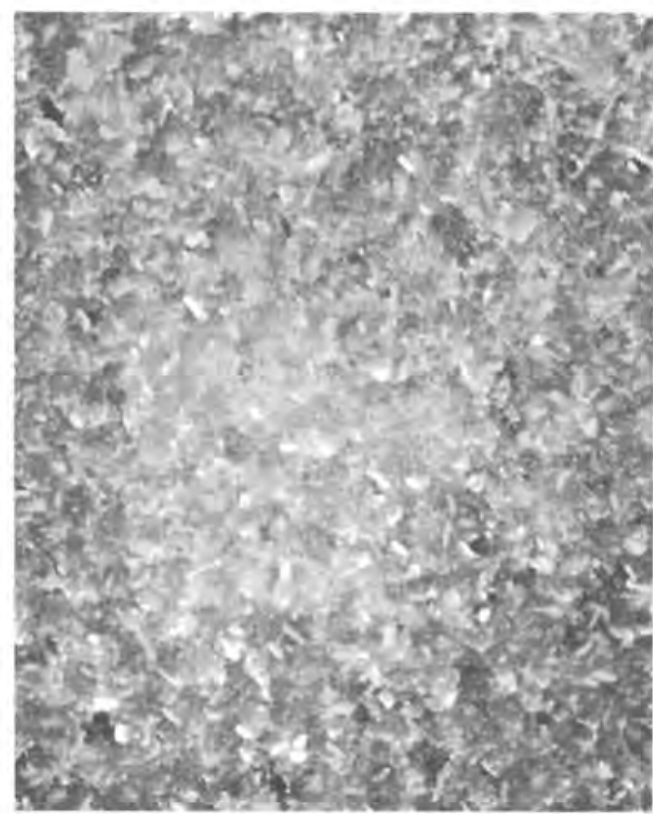

$750^{\circ} \mathrm{C}-2 \mathrm{~h}$

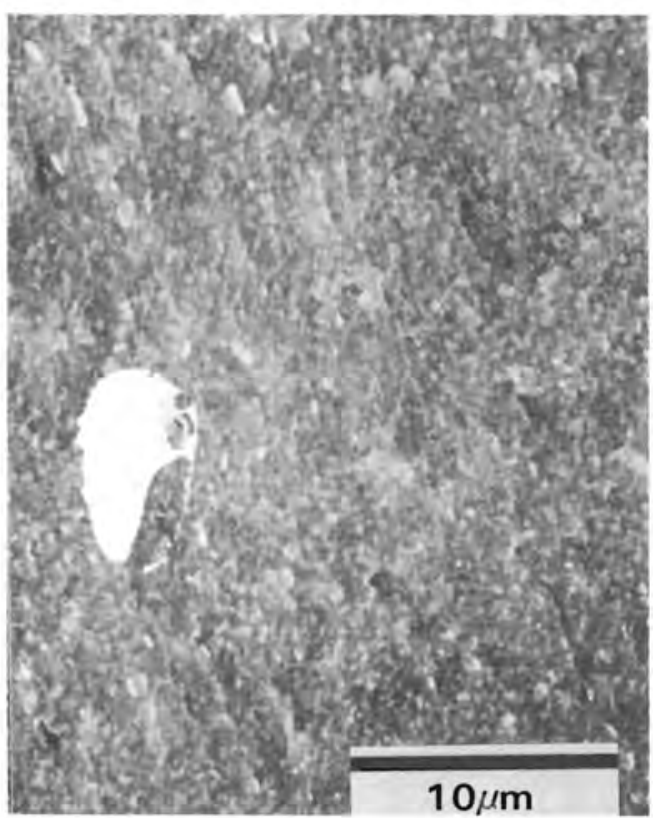

$800^{\circ} \mathrm{C}-2 \mathrm{~h}$

$950^{\circ} \mathrm{C}-8 \mathrm{~h}$

FIGURE 4. SEM Fractographs Showing Effect of Nucleation Temperature on Microstructure of Basalt Glass Crystallized for $8 \mathrm{~h}$ at $950^{\circ} \mathrm{C}$ 


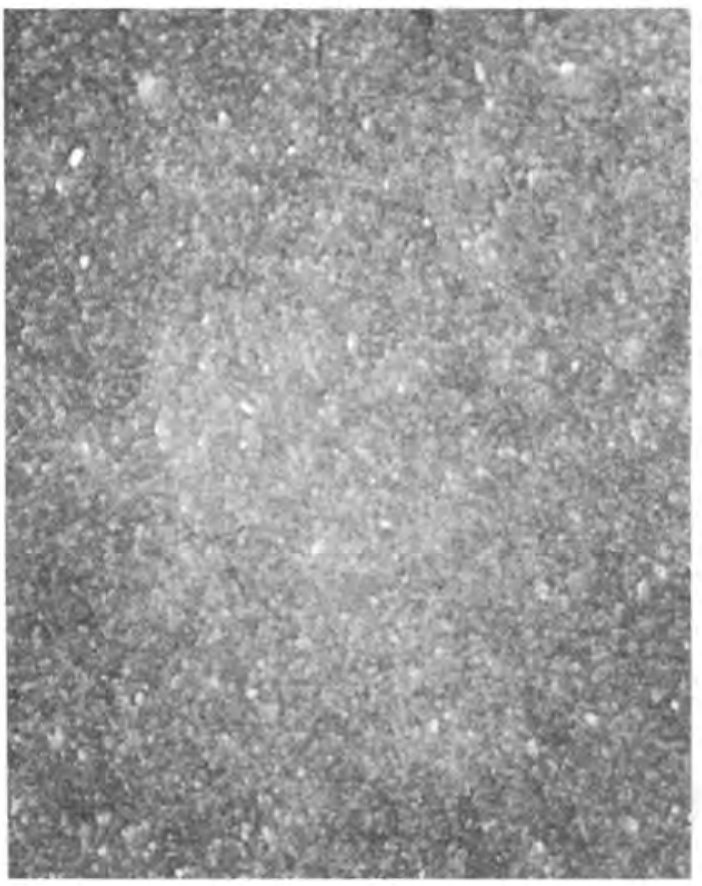

$700^{\circ} \mathrm{C}-2 \mathrm{~h} \quad 900^{\circ} \mathrm{C}-8 \mathrm{~h}$

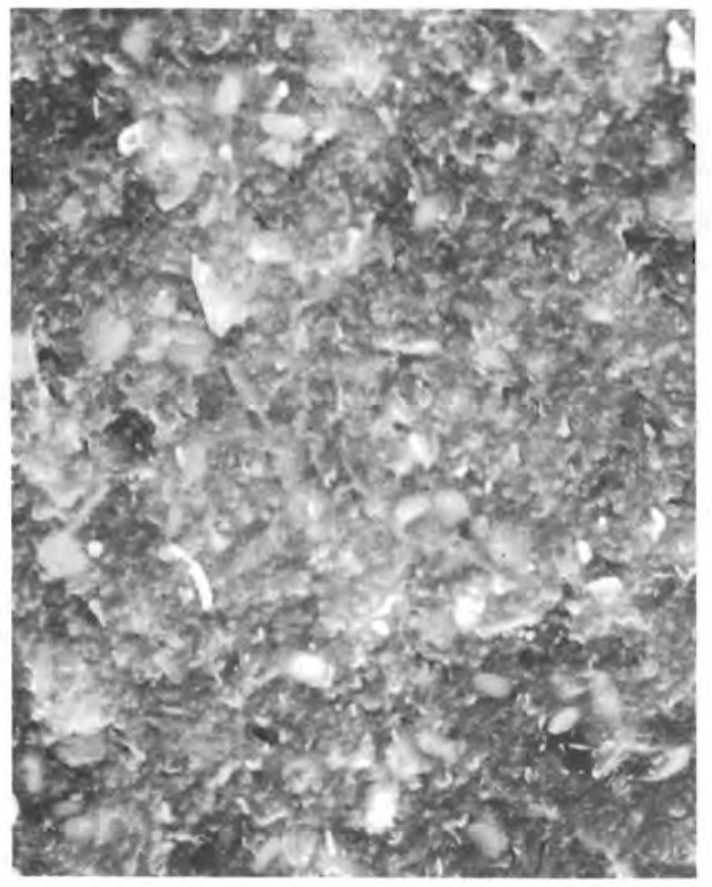

$700^{\circ} \mathrm{C}-2 \mathrm{~h} \quad 1000^{\circ} \mathrm{C}-8 \mathrm{~h}$
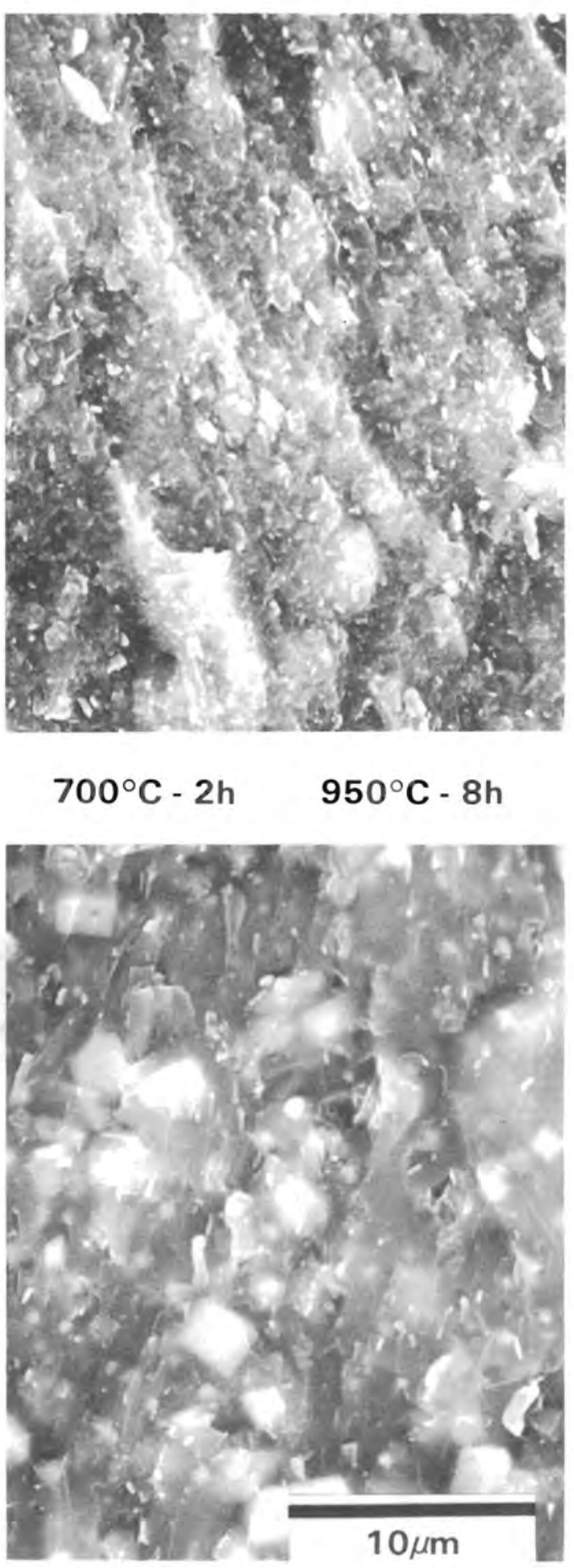

$700^{\circ} \mathrm{C}-2 \mathrm{~h} \quad 1050^{\circ} \mathrm{C}-8 \mathrm{~h}$

FIGURE 5. SEM Fractographs Showing Effect of Crystallization Temperature on Microstructure of Basalt Glass Nucleated $2 \mathrm{~h}$ at $700^{\circ} \mathrm{C}$ 


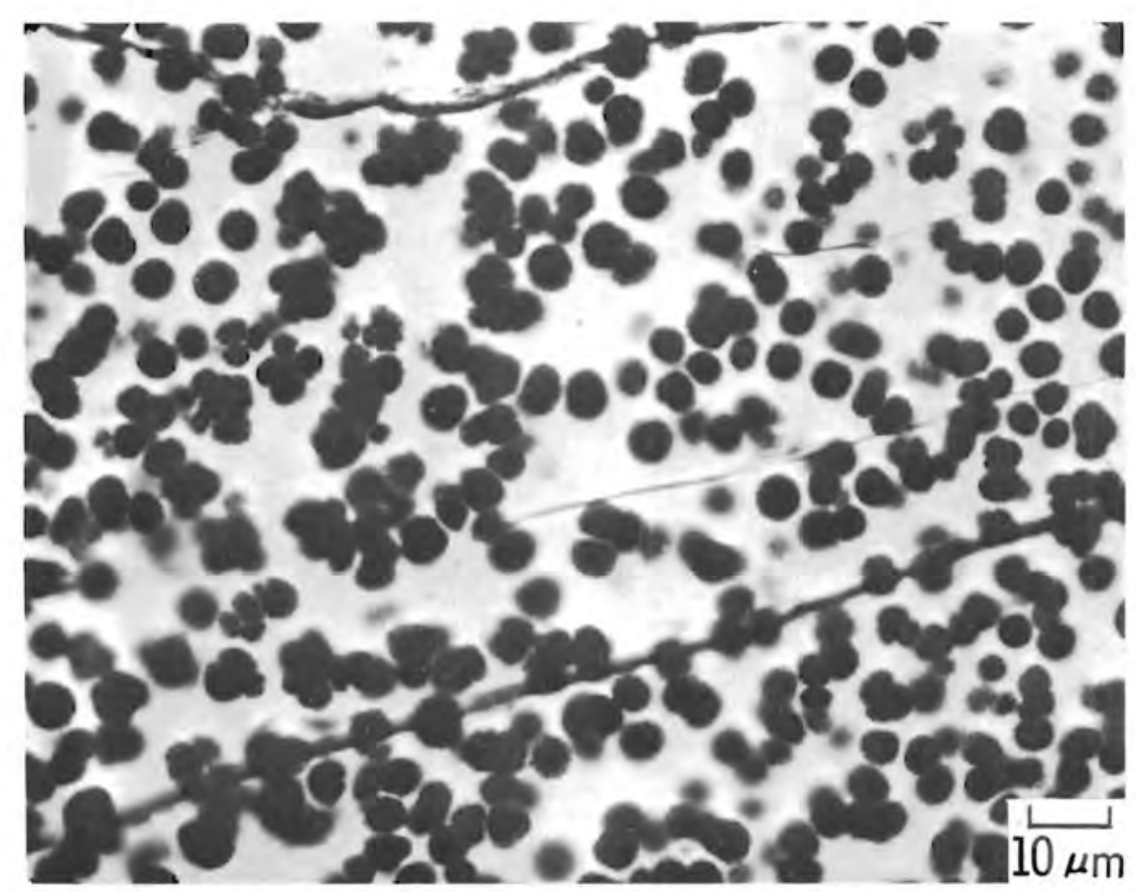

FIGURE 6. Optical Micrograph of Parent Glass SBG-63

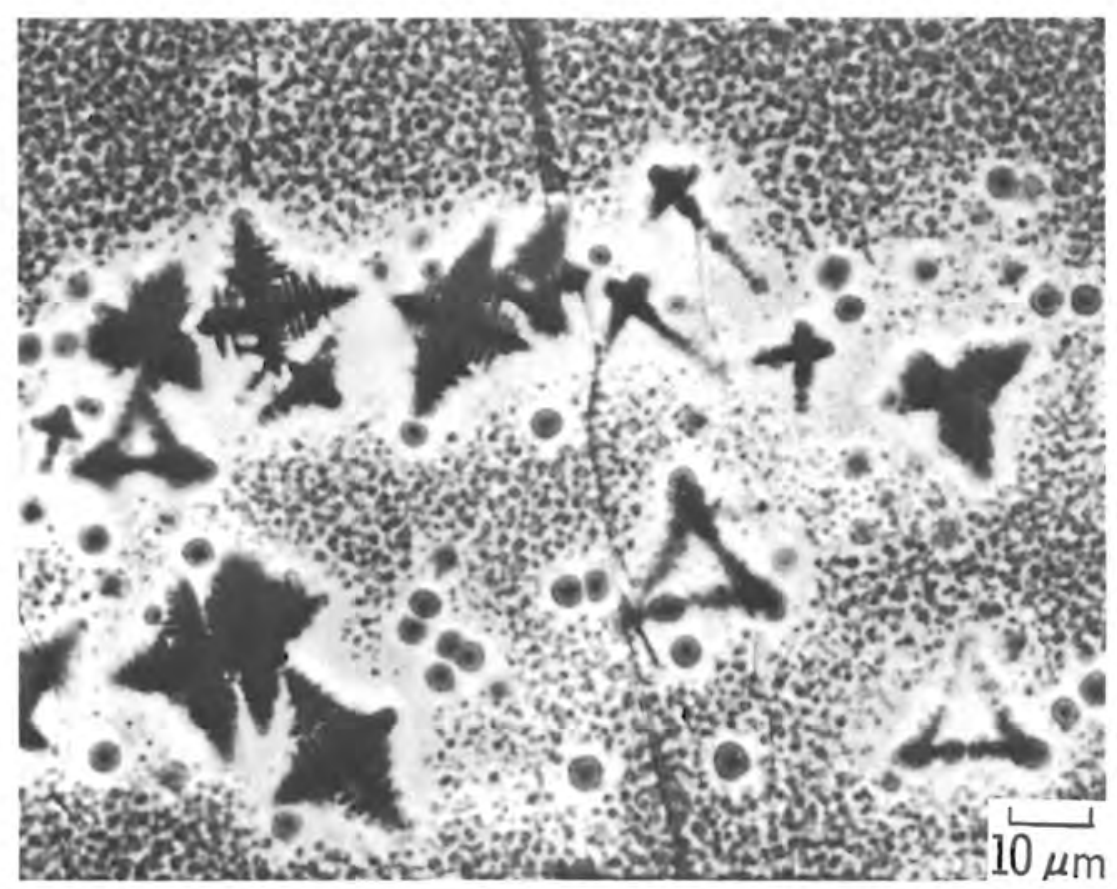

FIGURE 7. Optical Micrograph of Parent Glass BG-35 


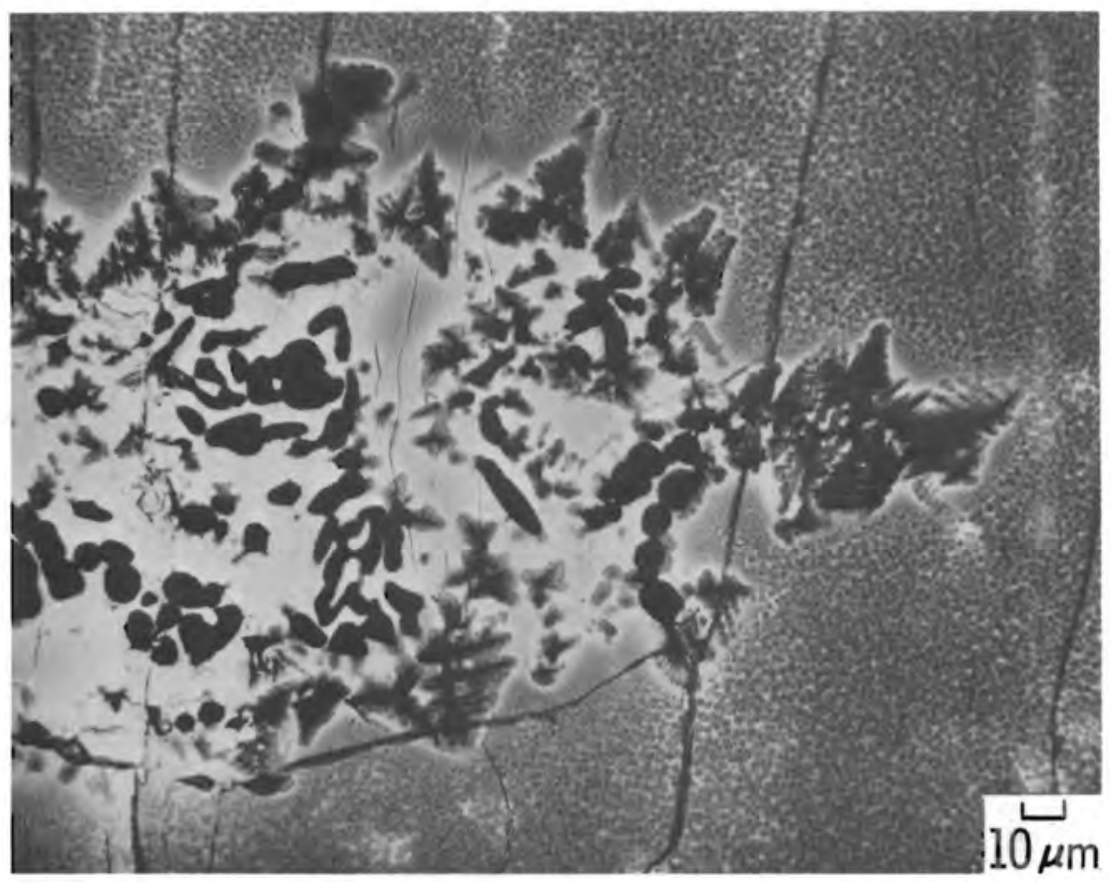

FIGURE 8. Optical Micrograph of Parent Glass BG-50 


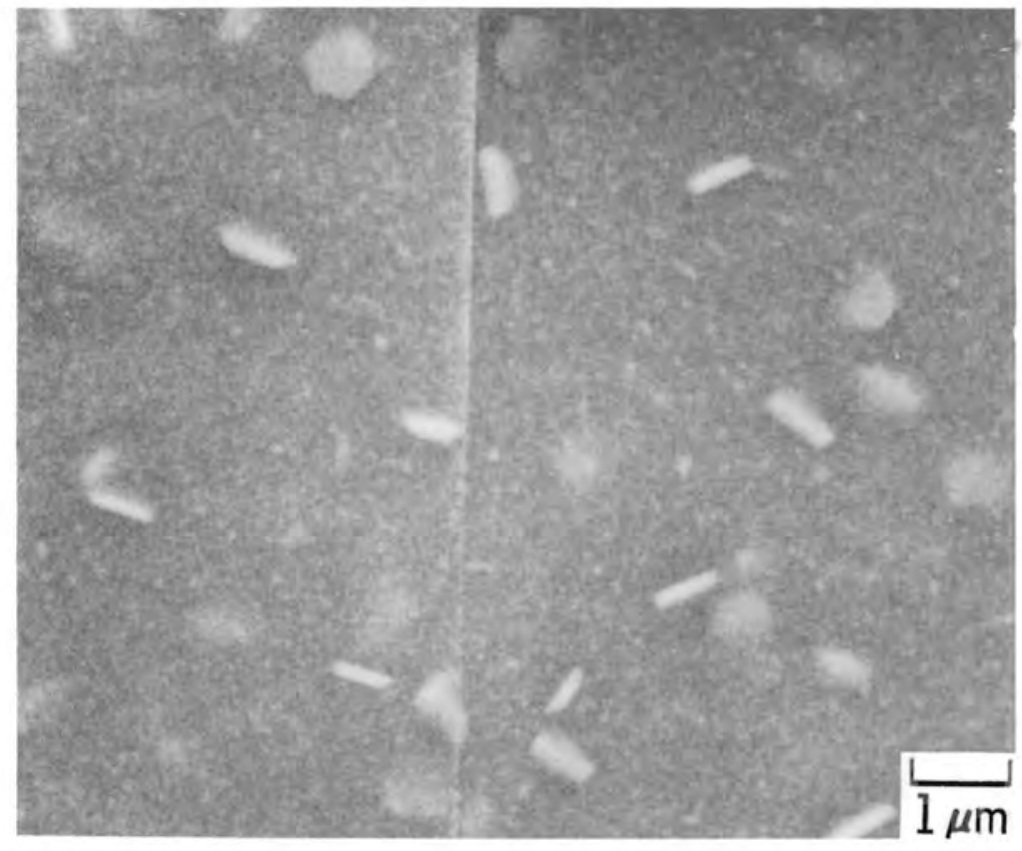

FIGURE 9. Polished Surface Scanning Electron Micrograph of Glass Ceramic BGC-35-1

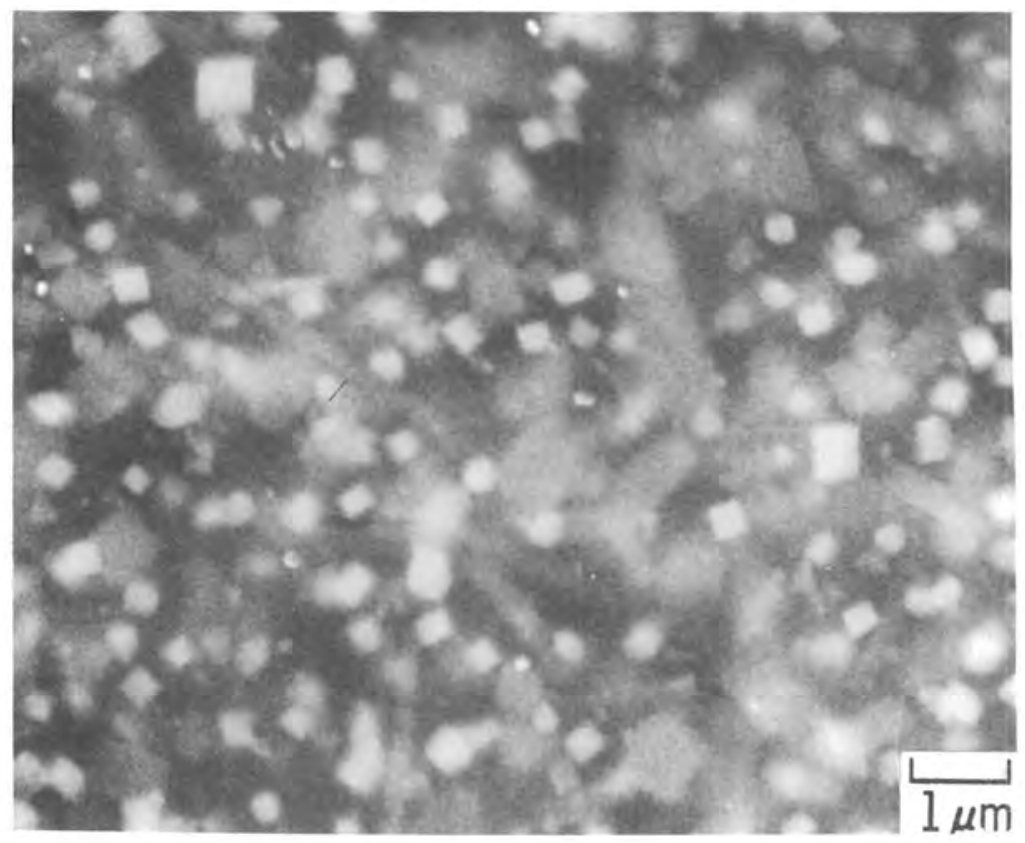

FIGURE 10. Polished Surface Scanning Electron Micrograph of Glass Ceramic BGC-35-2 


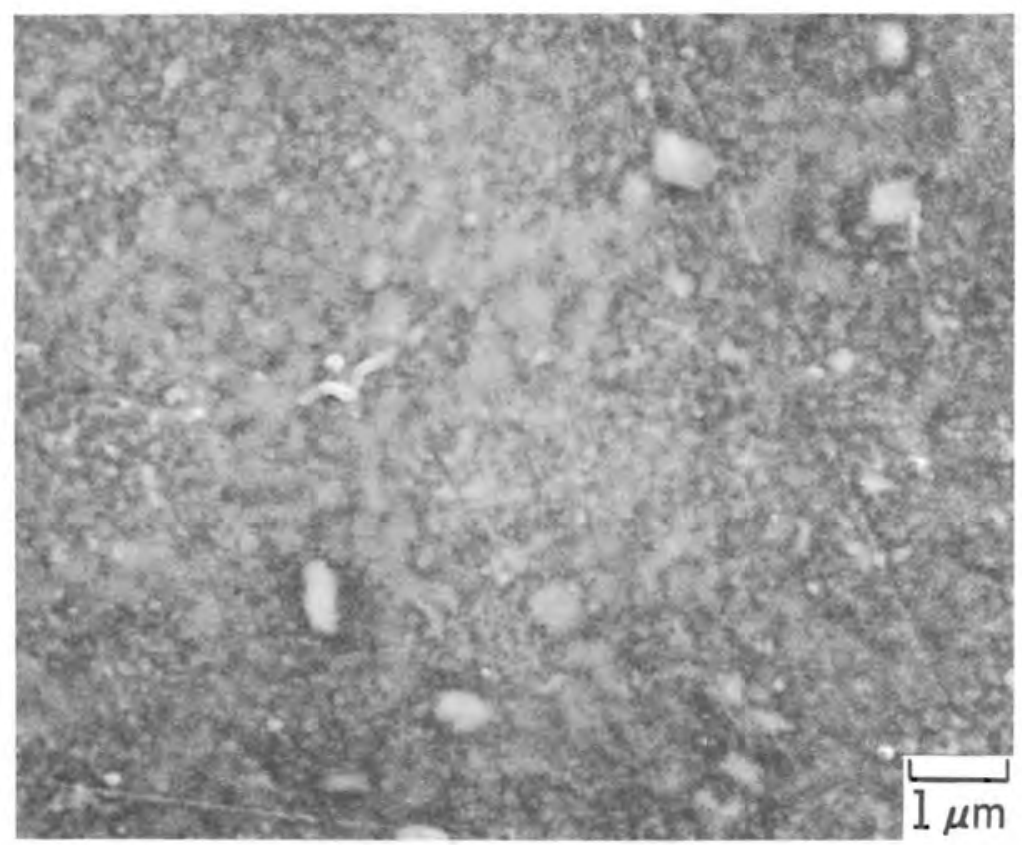

FIGURE 11. Polished Surface Scanning Electron Micrograph of G1ass Ceramic BGC-50

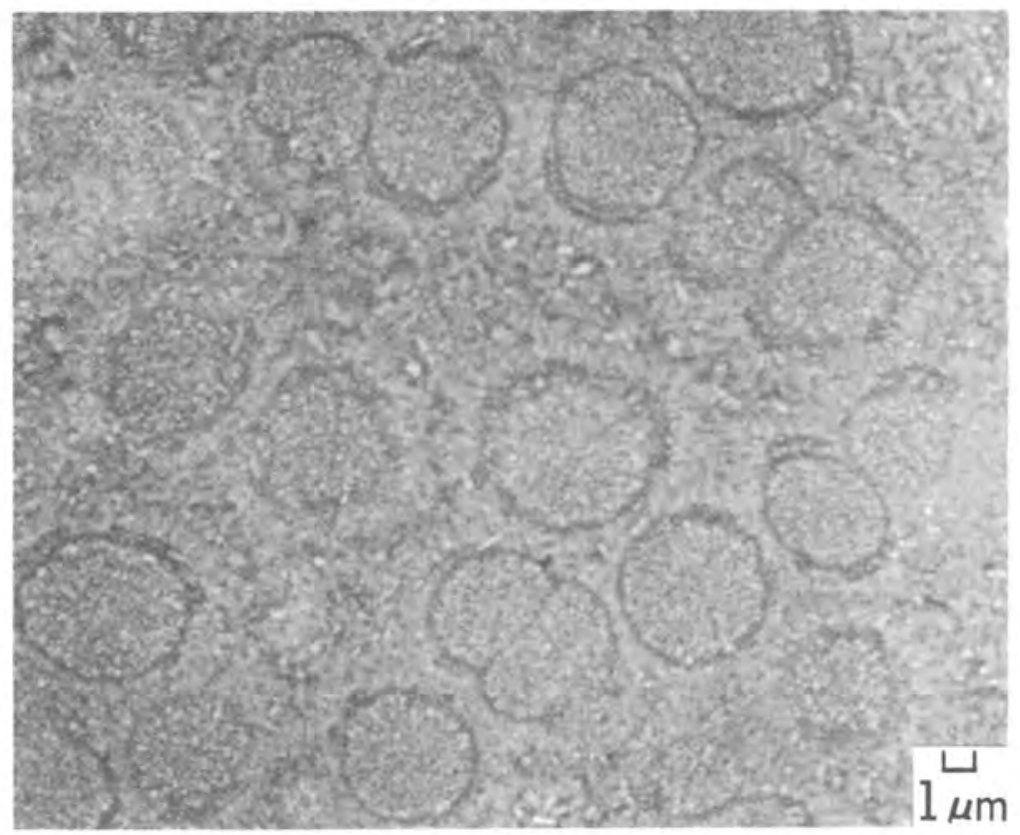

FIGURE 12. Polished Surface Scanning Electron Micrograph of Glass Ceramic SBGC-63 


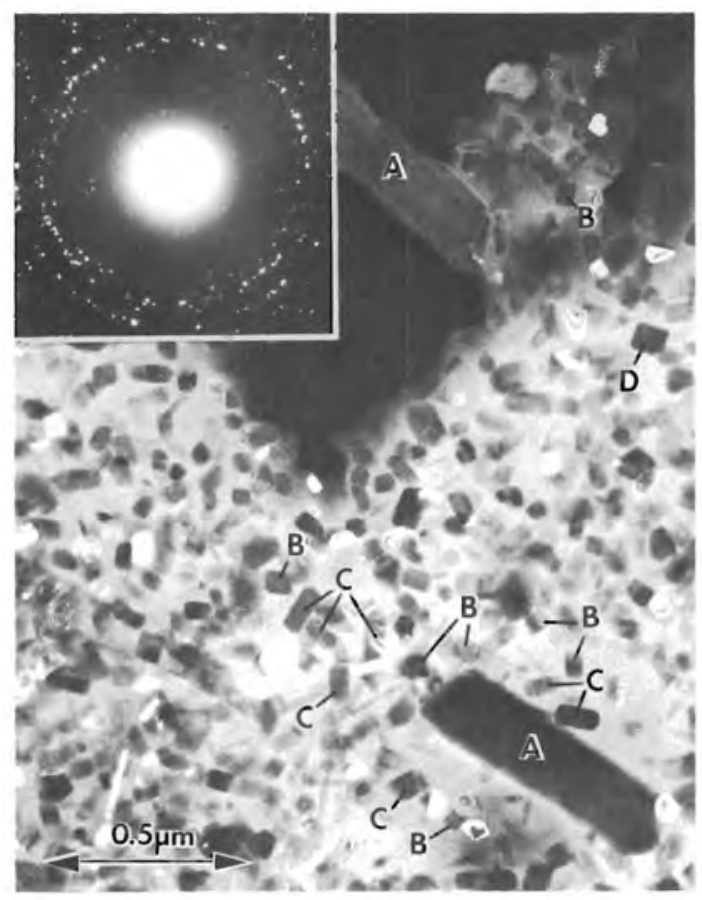

FIGURE 13. Darkfield TEM Micrograph of Glass Ceramic BGC-35-1

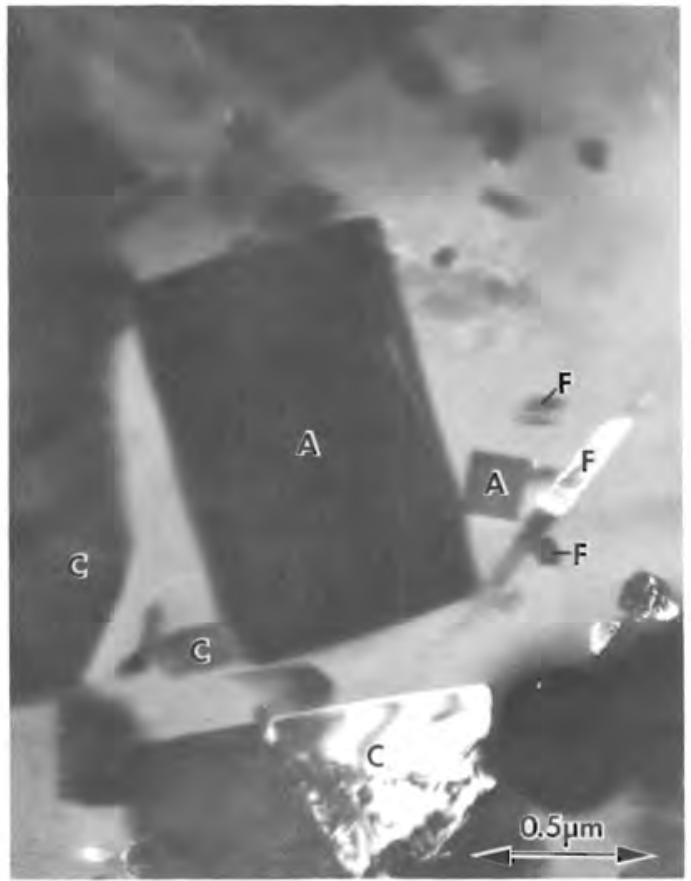

FIGURE 14. Darkfield TEM Micrograph of Glass Ceramic BGC-35-2 50 


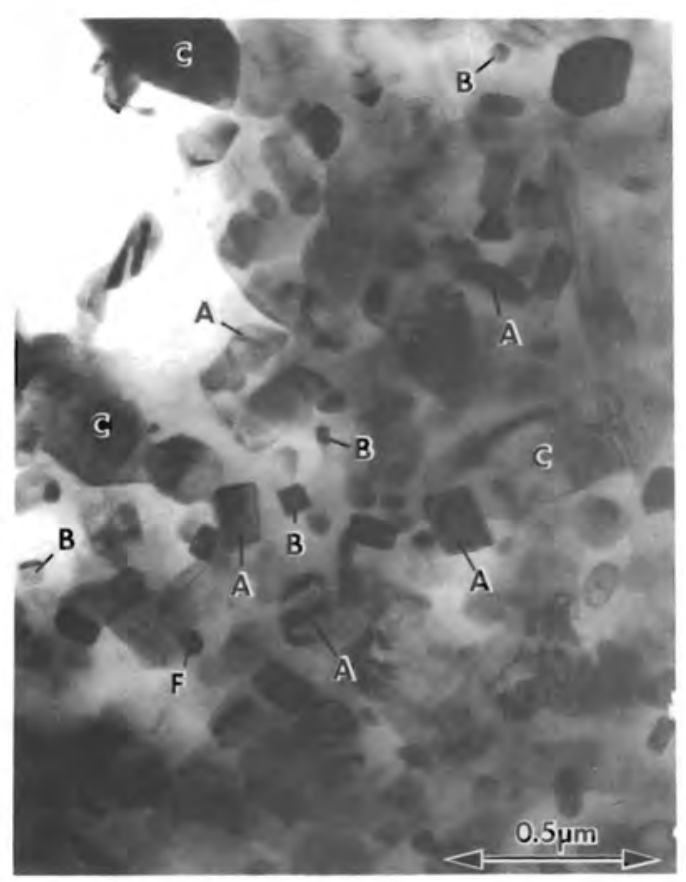

FIGURE 15. Brightfield TEM Micrograph of Glass Ceramic SBGC-63
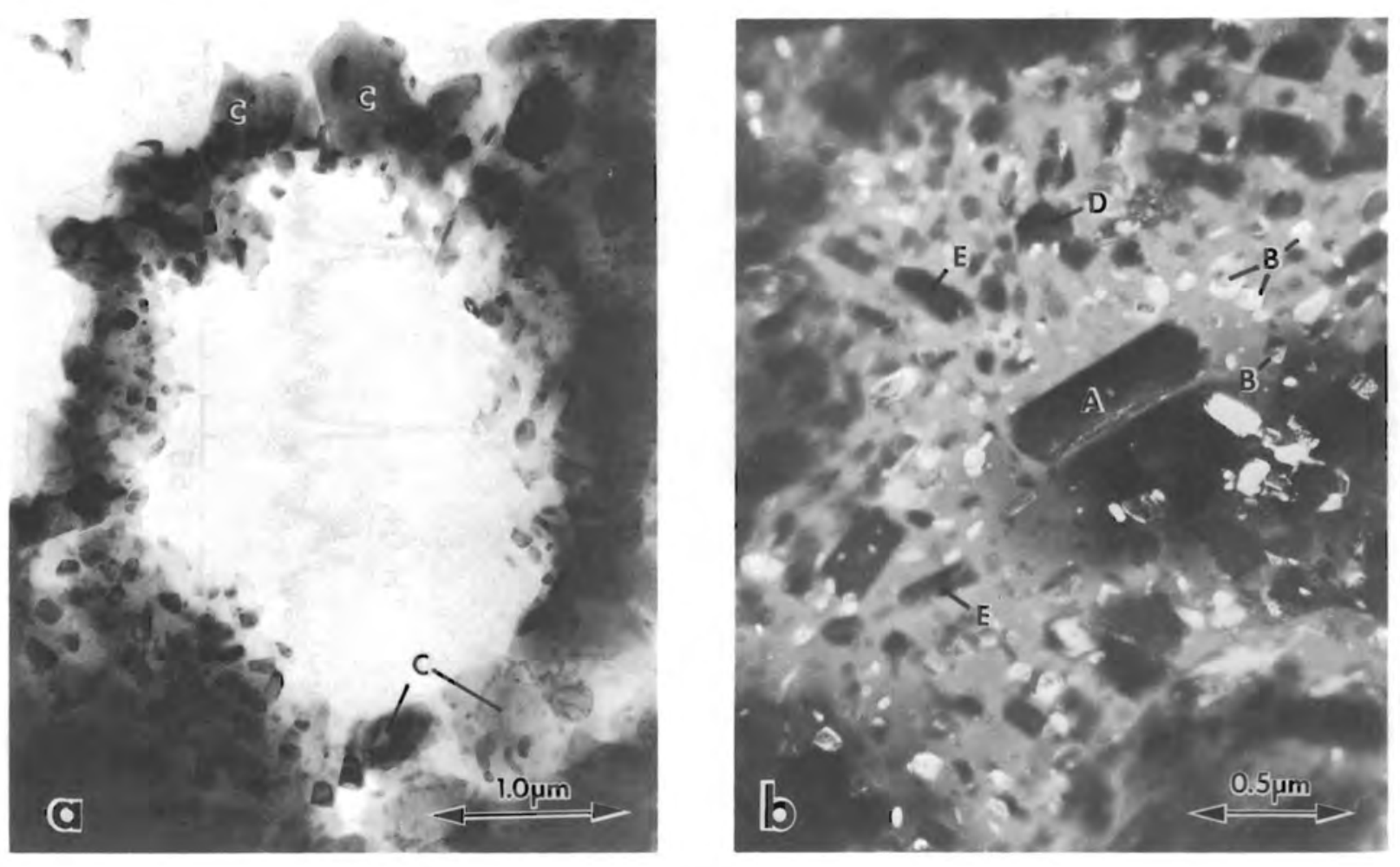

FIGURE 16. Brightfield and Darkfield TEM Micrographs of Glass Ceramic BGC-50 51 

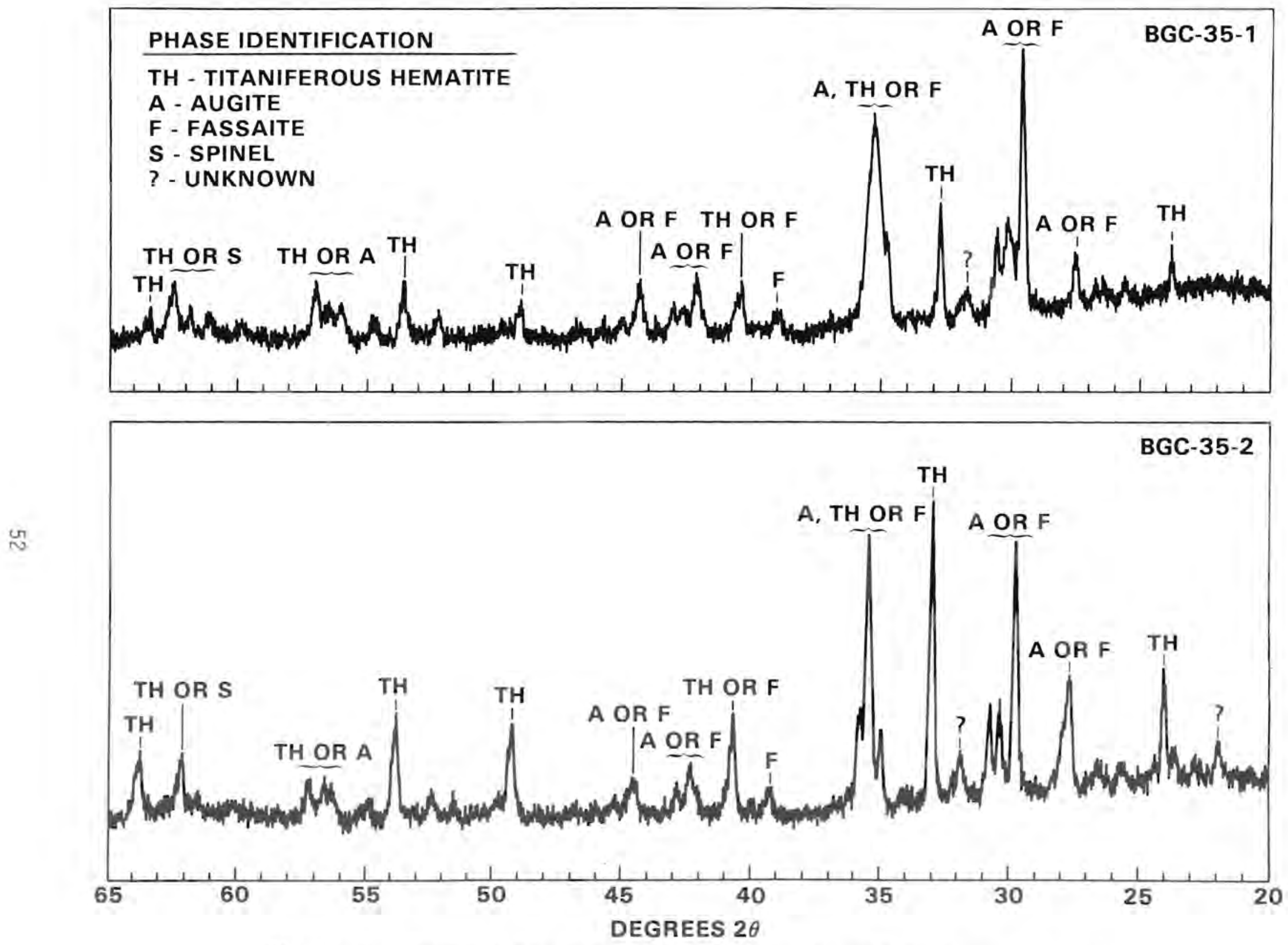

FIGURE 17. Powder X-Ray Diffraction Pattern for BGC-35-1 and BGC-35-2 

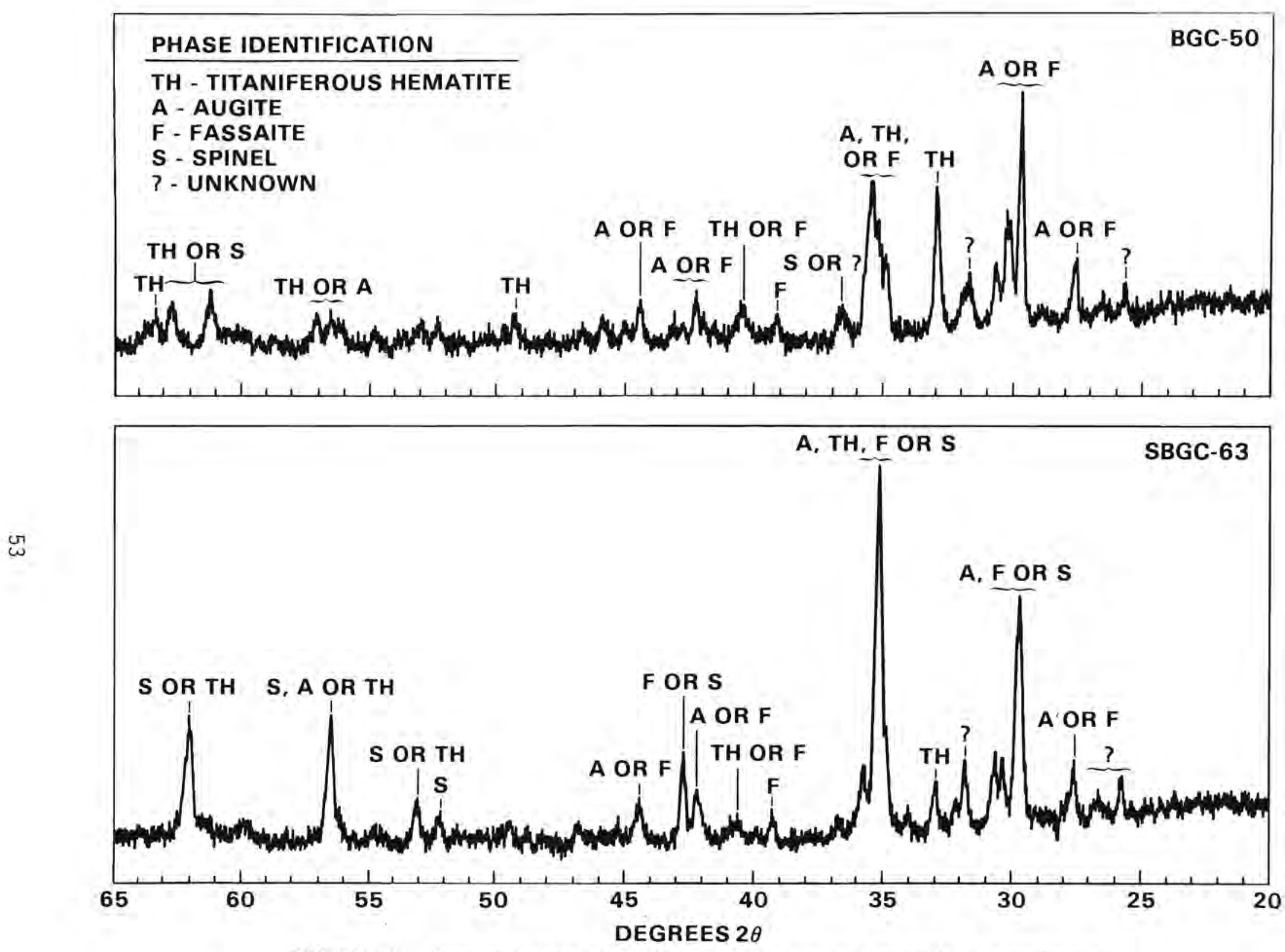

FIGURE 18. Powder X-Ray Diffraction Pattern for BGC-50 and SBGC-63. 


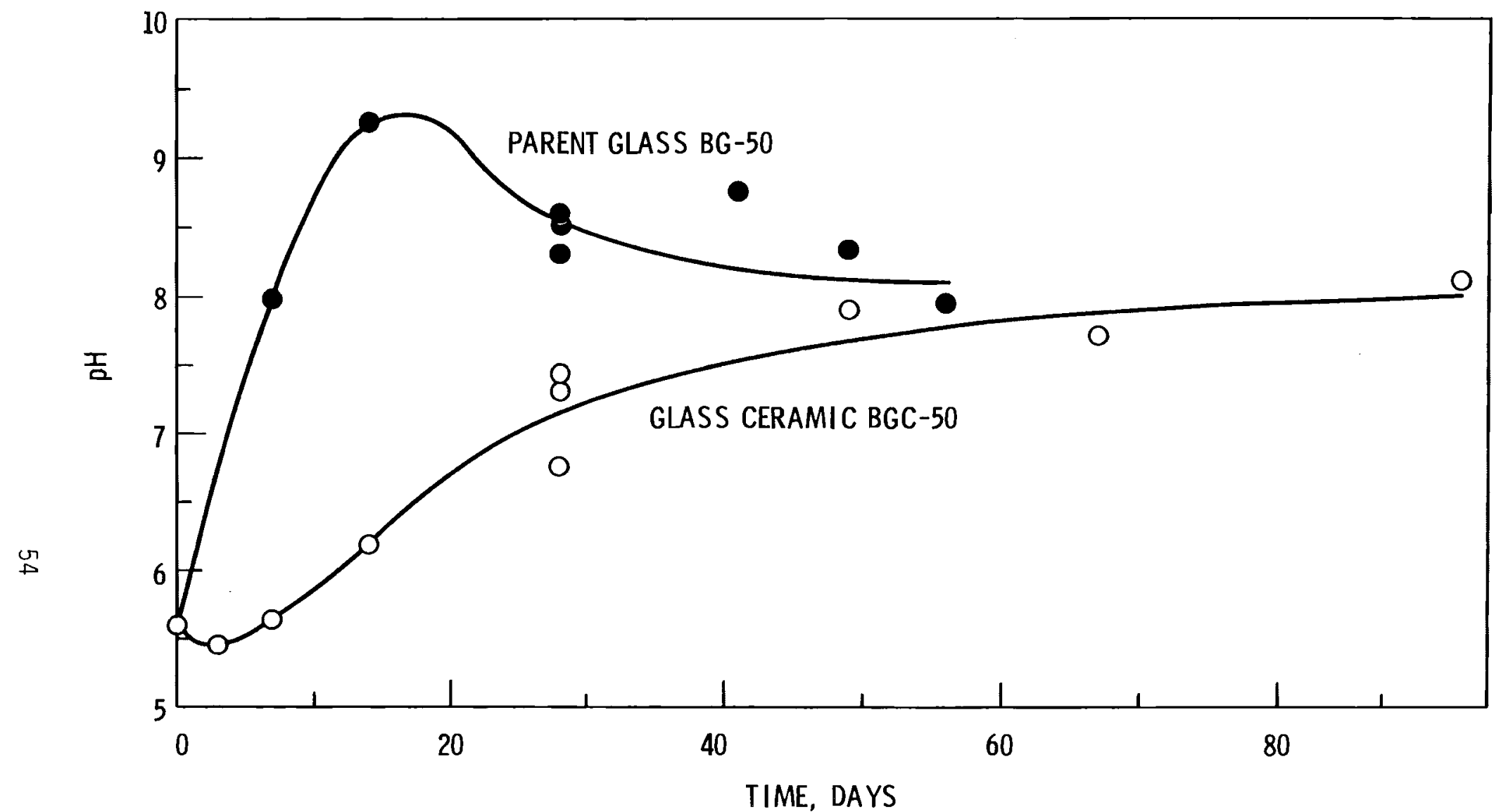

FIGURE 19. Solution $\mathrm{pH}$ for Static MCC-1 Leach Test 


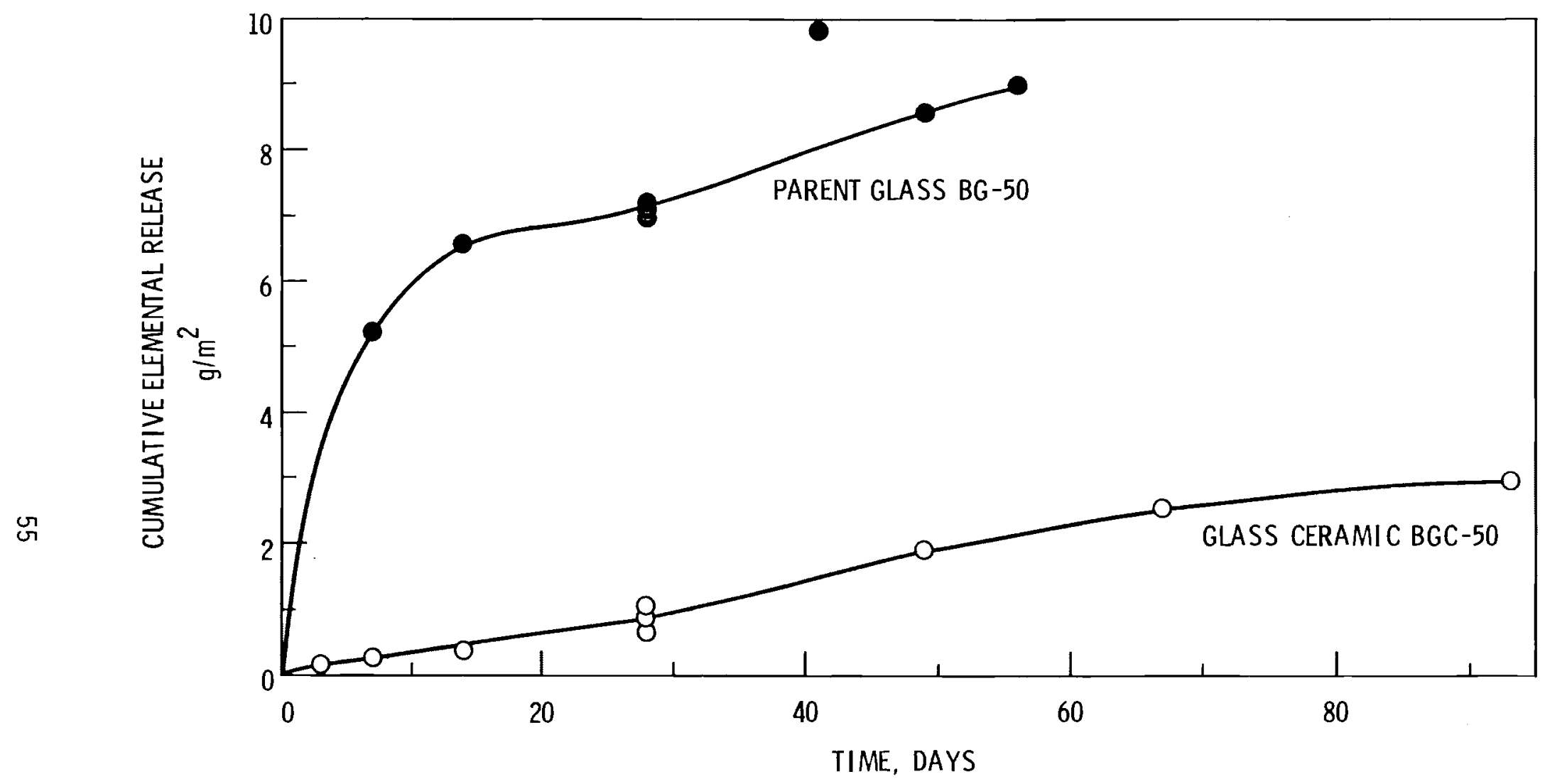

FIGURE 20. Normalized Cumulative Silicon Release 


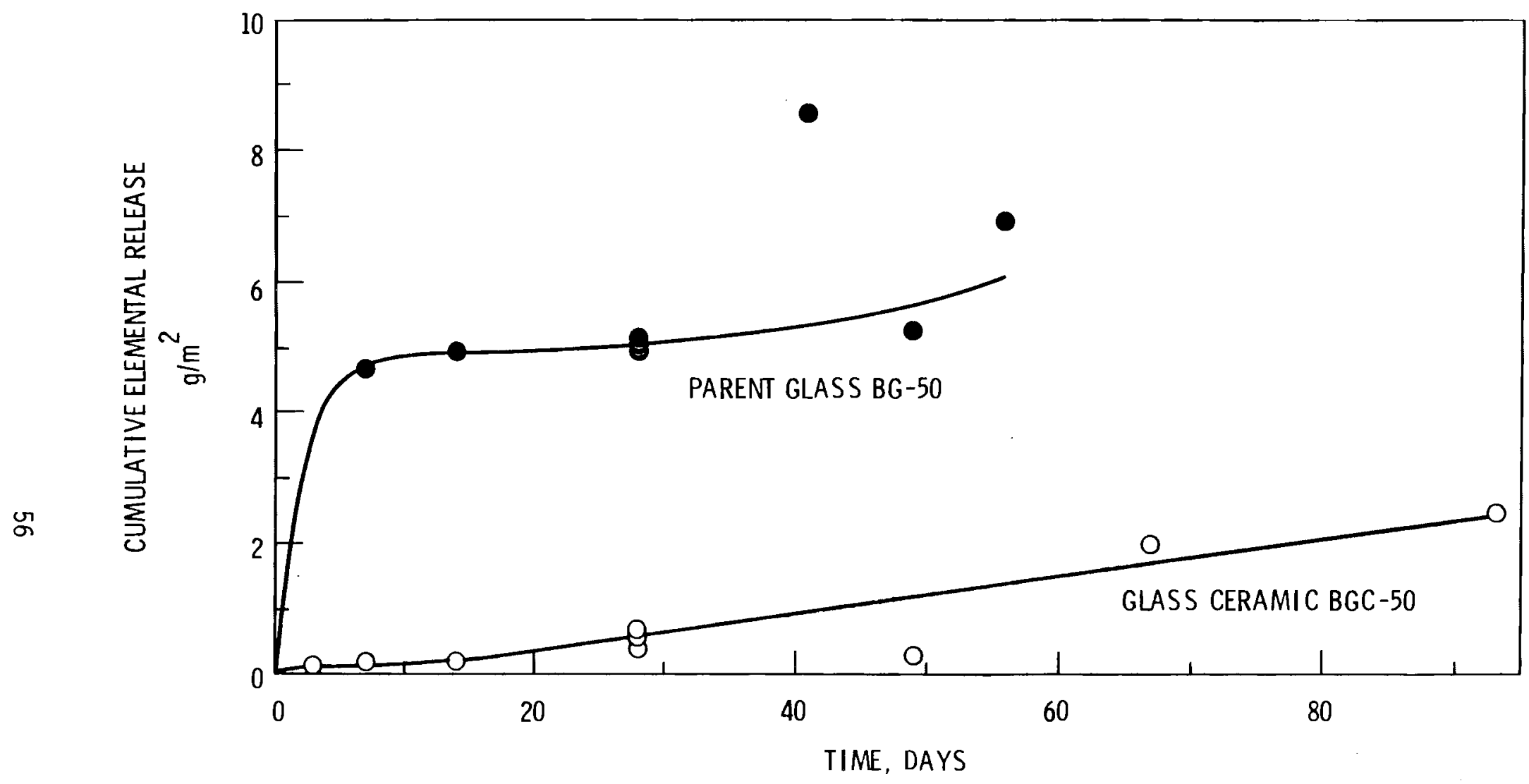

FIGURE 21. Normalized Cumulative Aluminum Release 


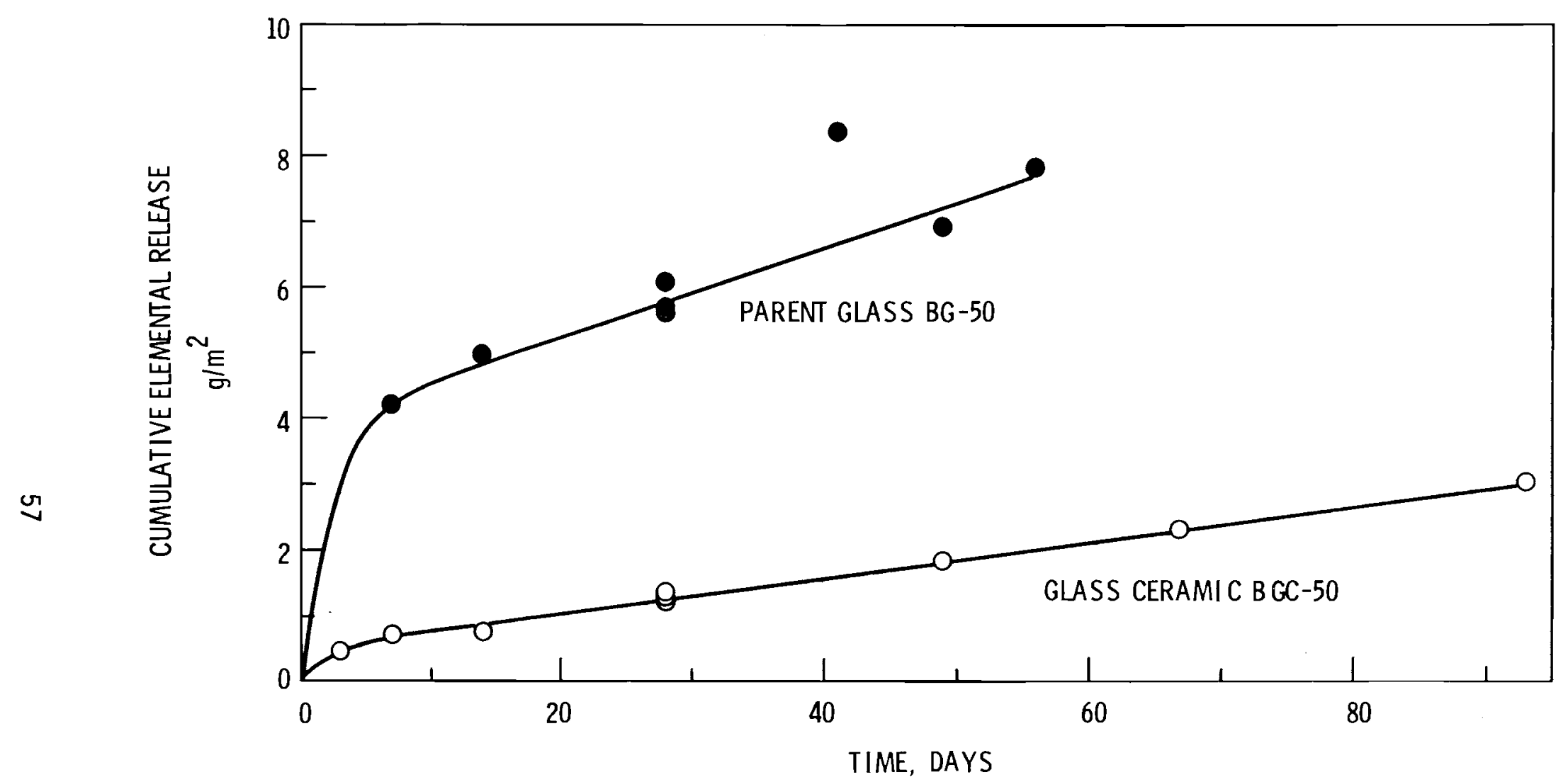

FIGURE 22. Normalized Cumulative Sodium Release 


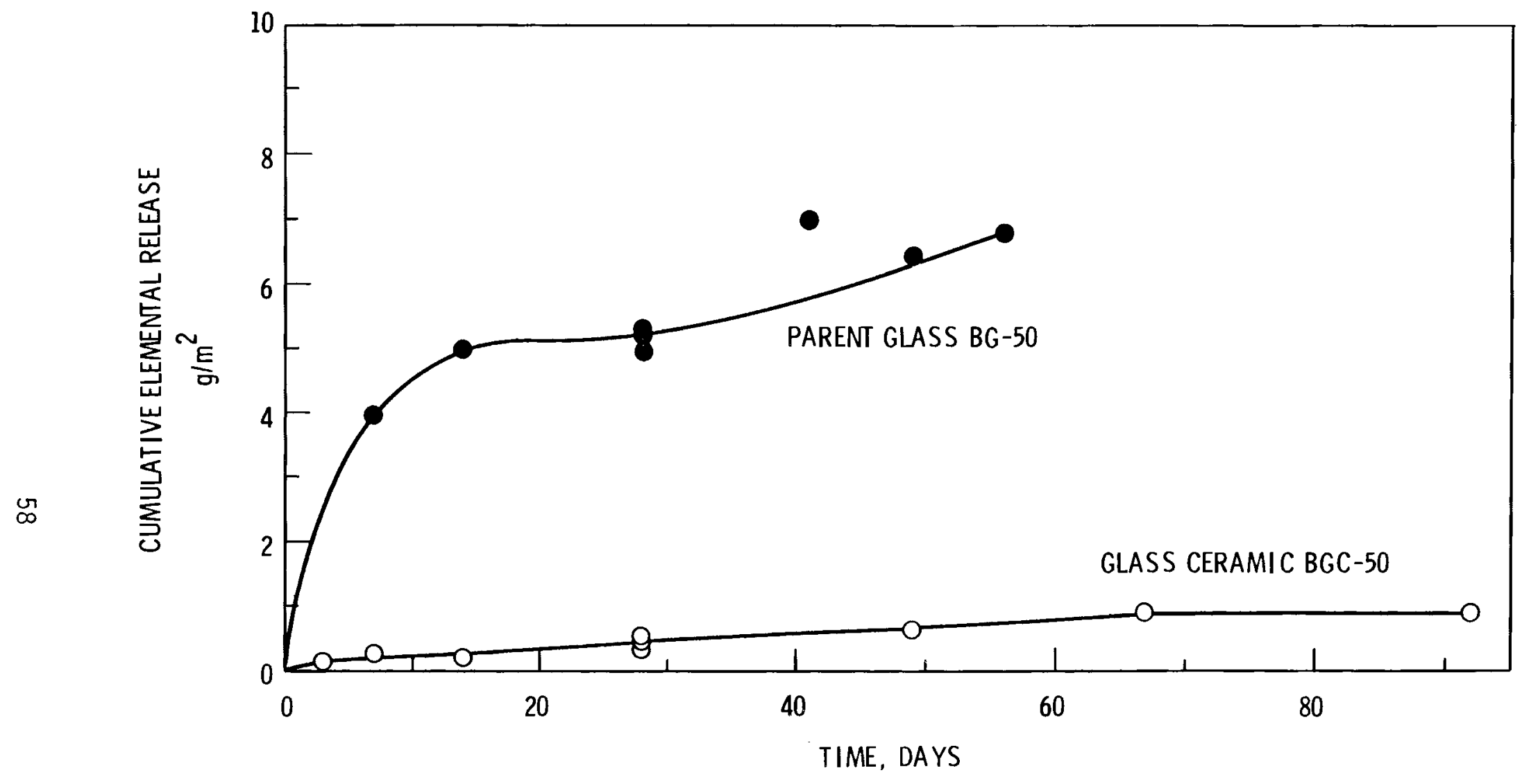

FIGURE 23. Normalized Cumulative Calcium Release 


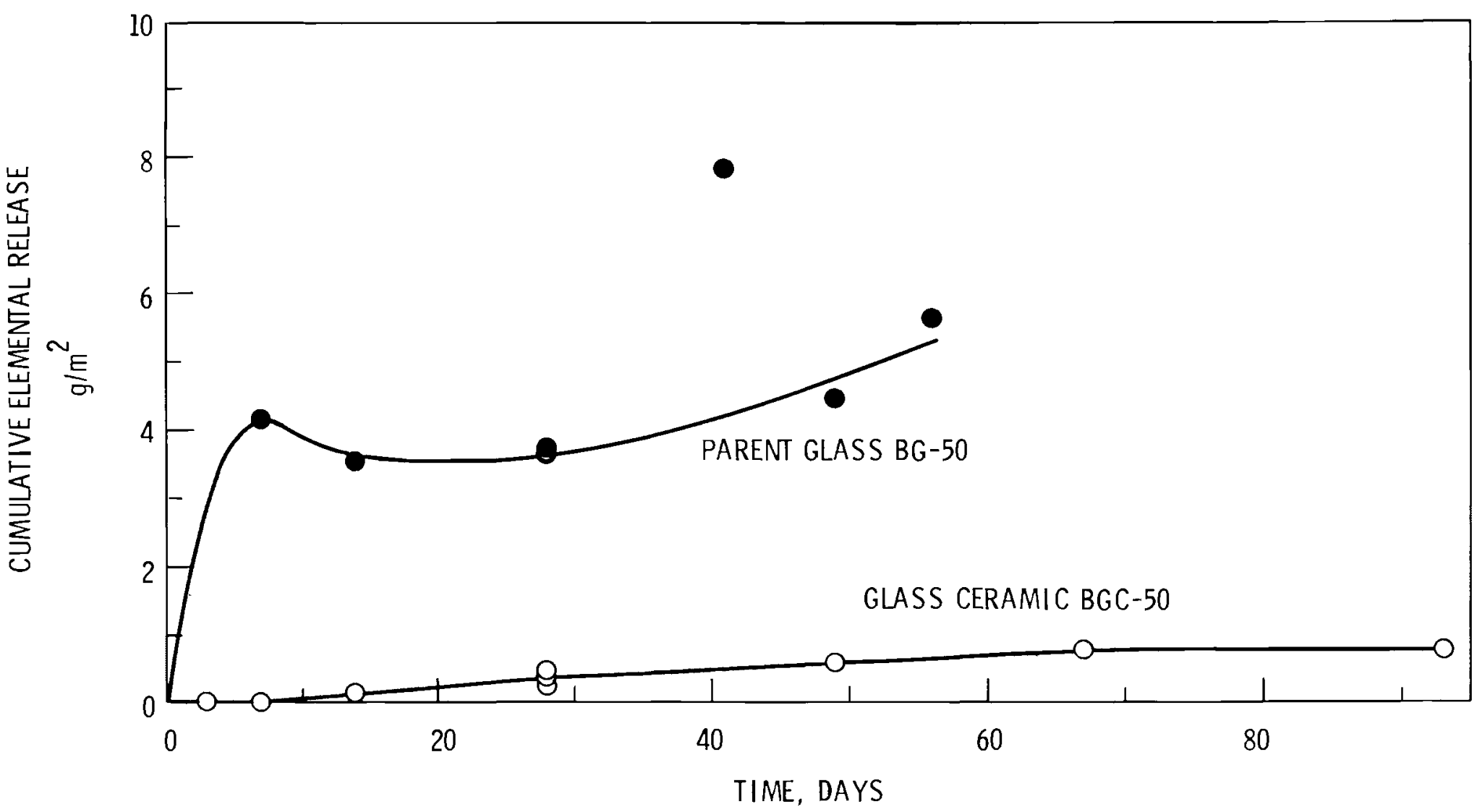

FIGURE 24. Normalized Cumulative Magnesium Release 


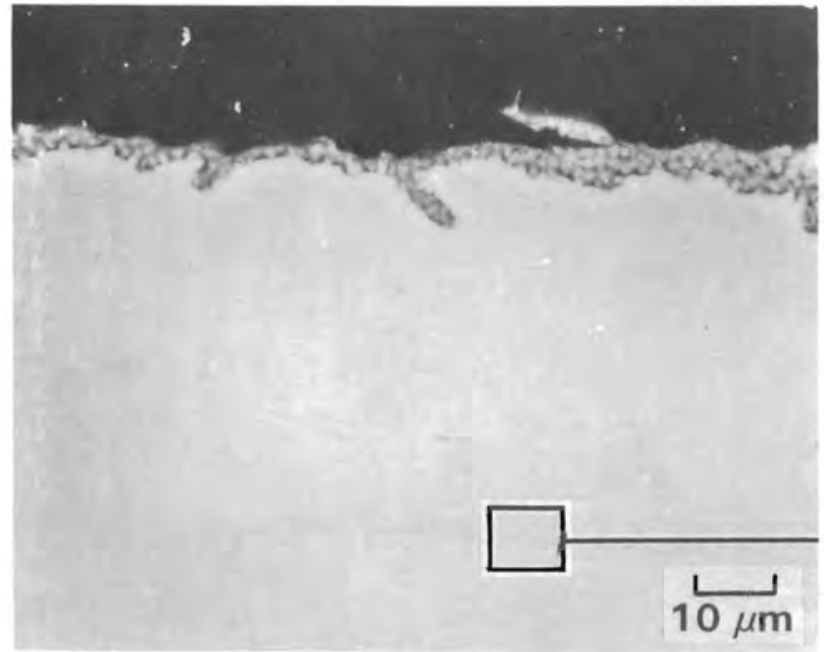

A
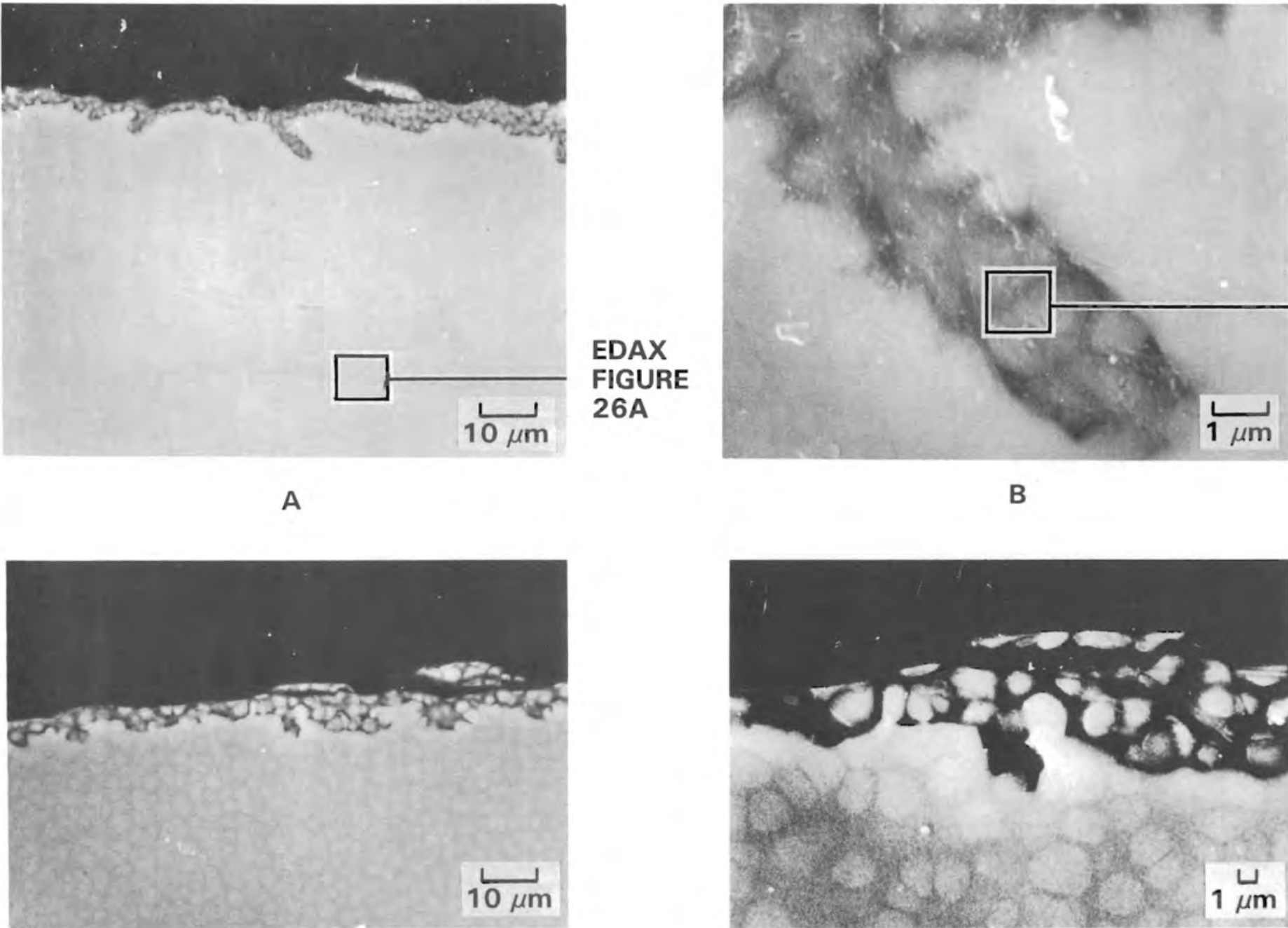

C
B

EDAX

FIGURE

26B

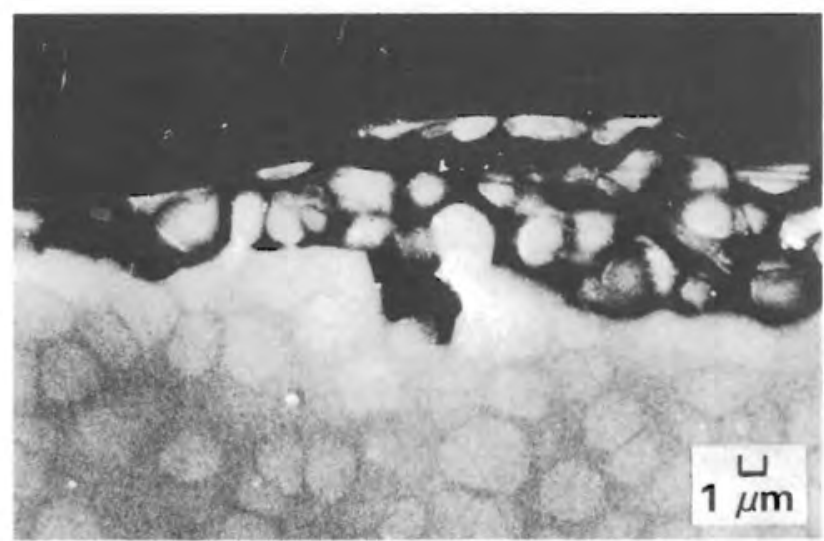

D

FIGURE 25. Scanning Electron Micrographs of Parent Glass BG-50 After Leaching. $A$ and $B, 28$ days leaching; $C$ and $D, 41$ days leaching. 

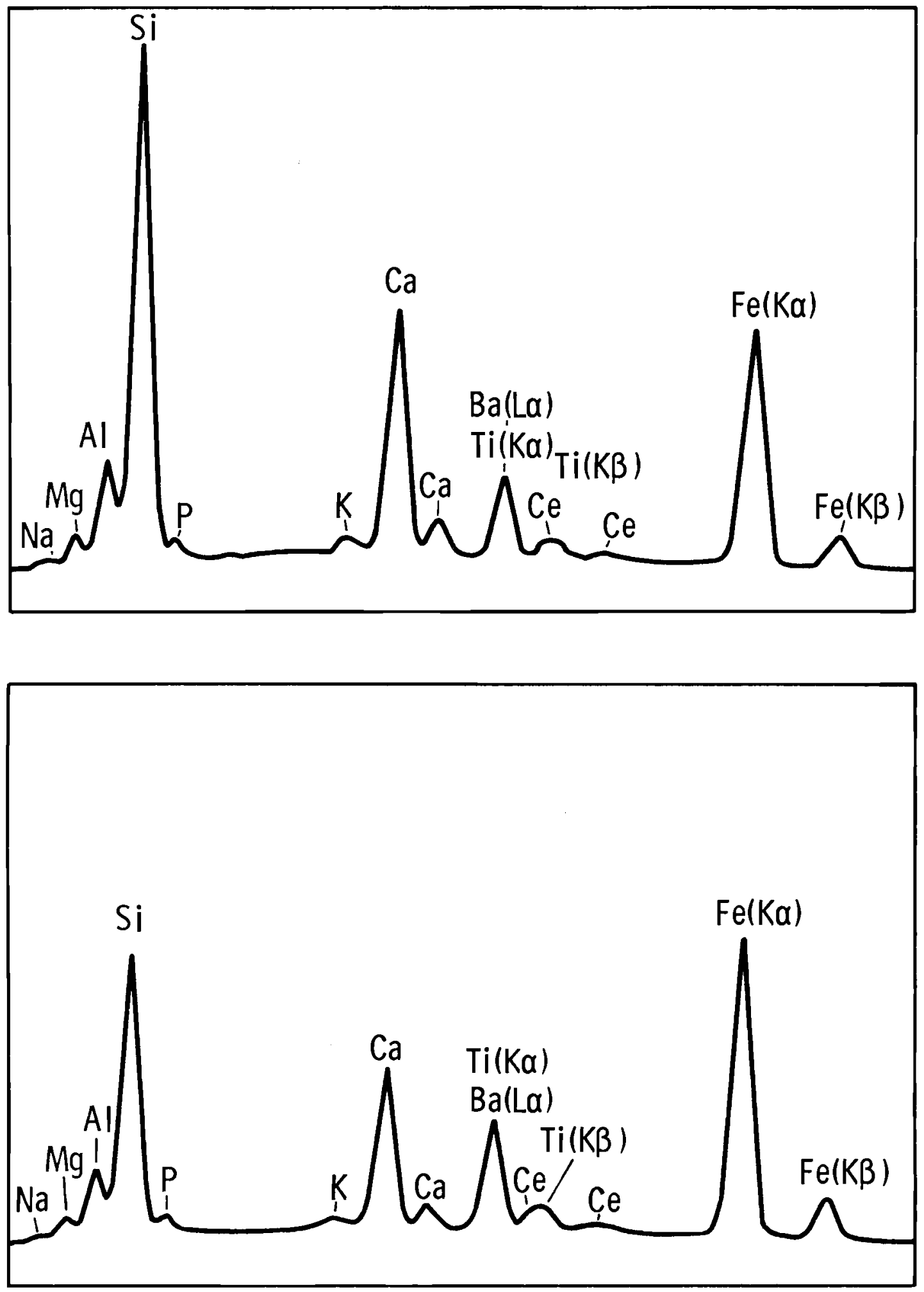

FIGURE 26. Energy Dispersive X-Ray Spectra of Leached Parent Glass BG-50. $A$, spectra of unleached bulk glass (see Figure 25). B, spectra of gel material in leached surface (see Figure 25b). 


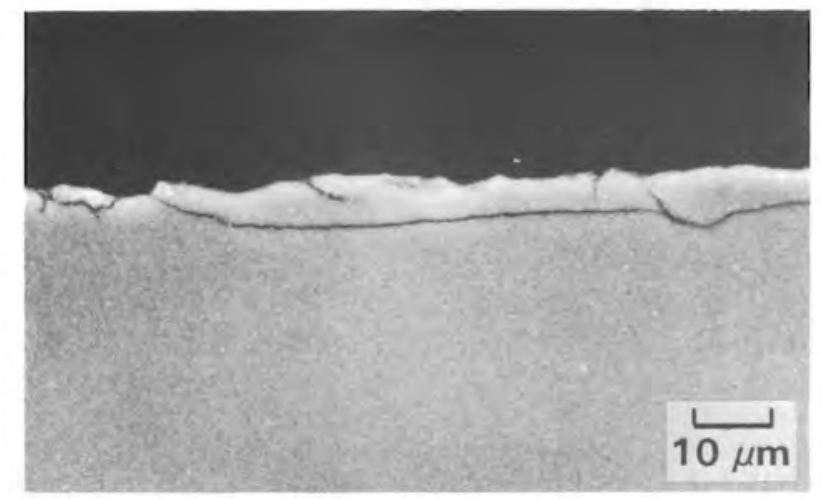

A

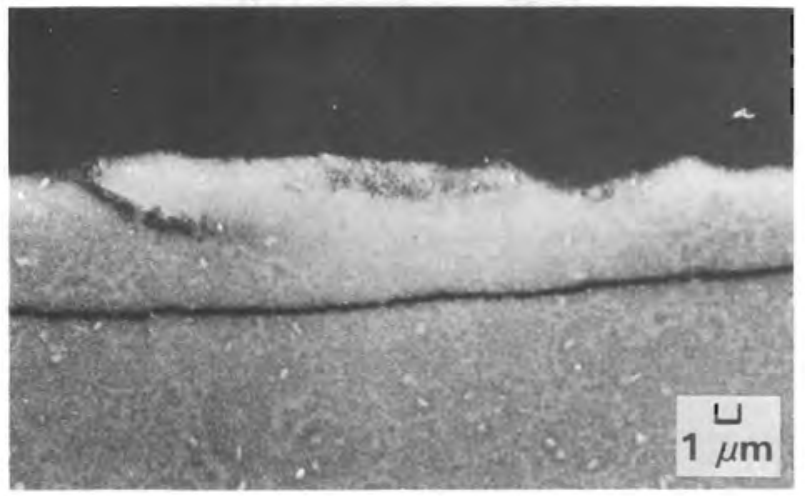

B

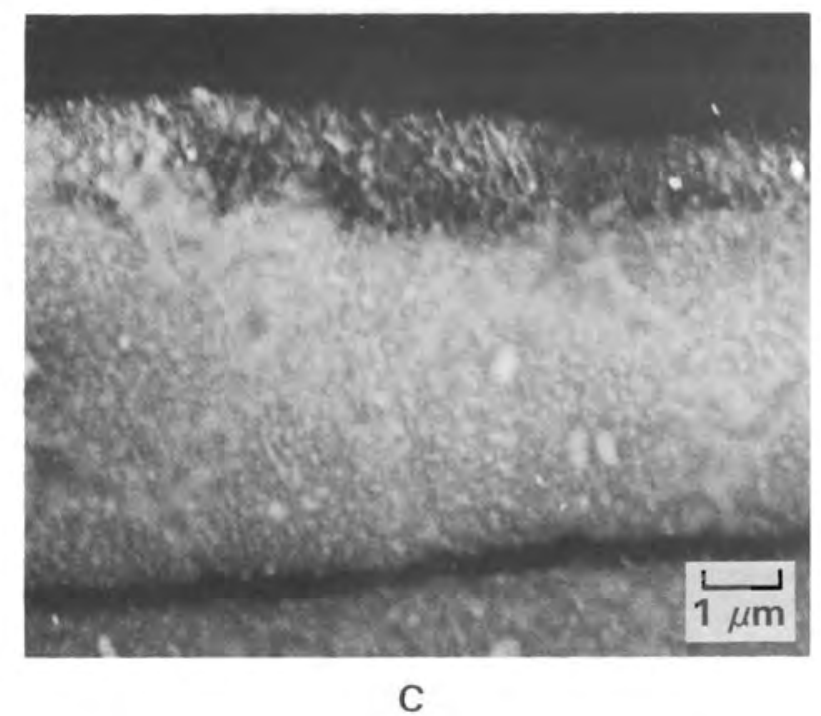

FIGURE 27. Scanning Electron Micrographs of Glass Ceramic BGC-50 After Leaching for 67 Days. $B$ and $C$ are increased magnifications at the center of $A$. 


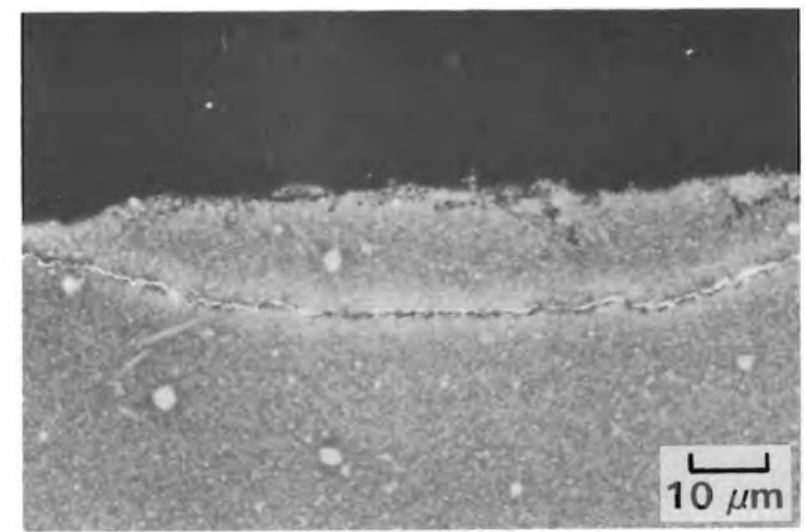

A

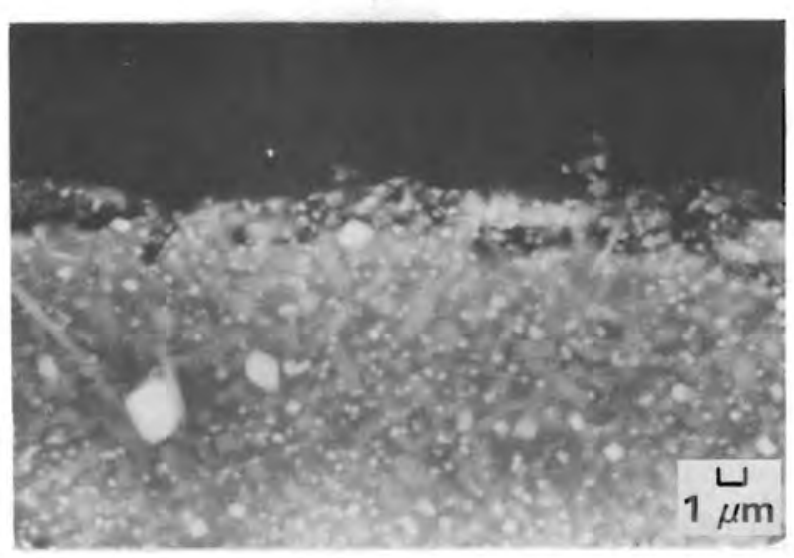

B

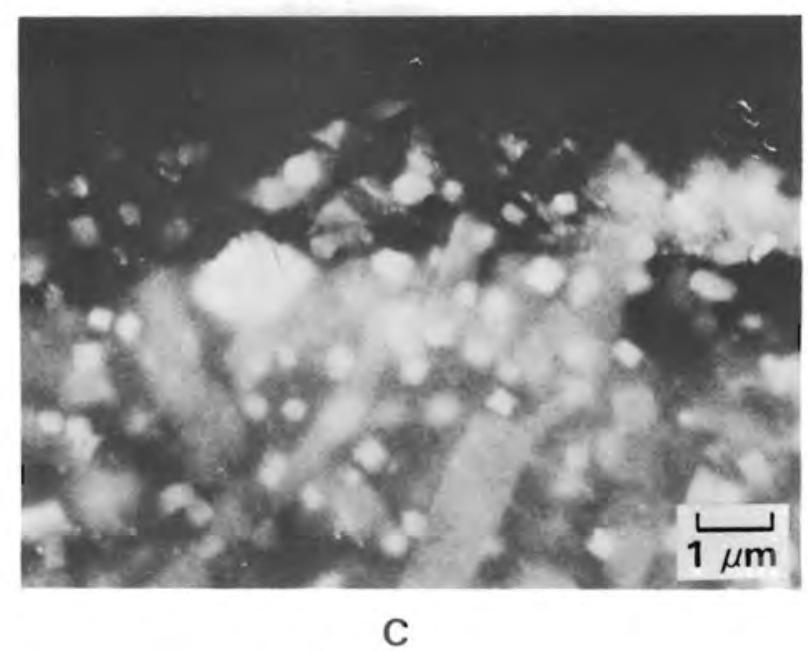

FIGURE 28. Scanning Electron Micrographs of Glass Ceramic BGC-35-2 After Leaching for 67 Days. $B$ and $C$ are increased magnifications at the center of $A$. 


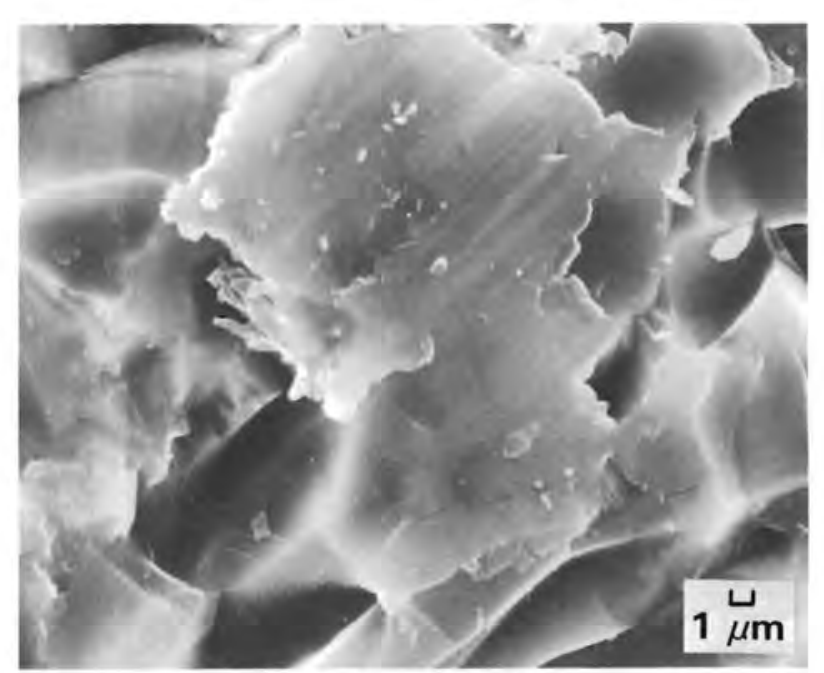

A

$\stackrel{\leftrightarrow}{\perp}$

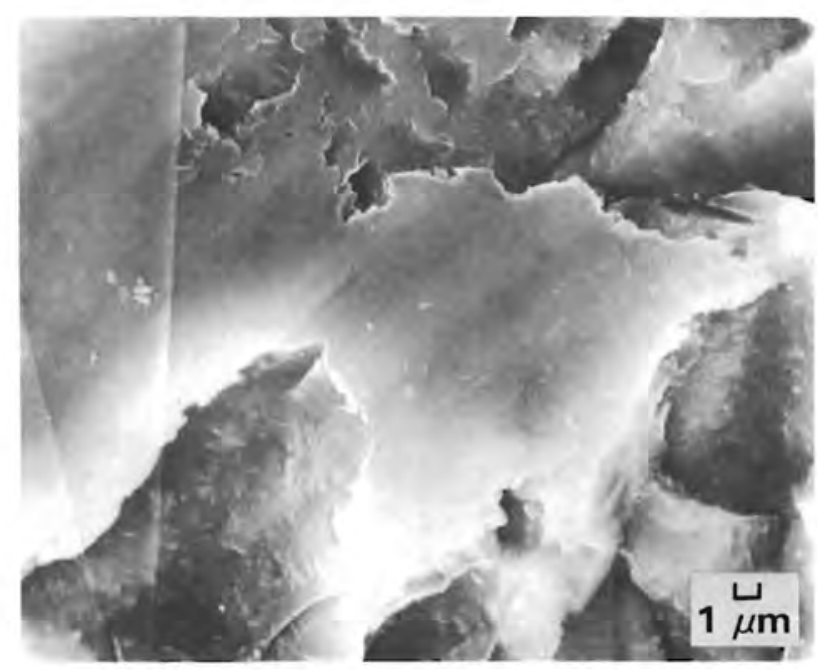

B

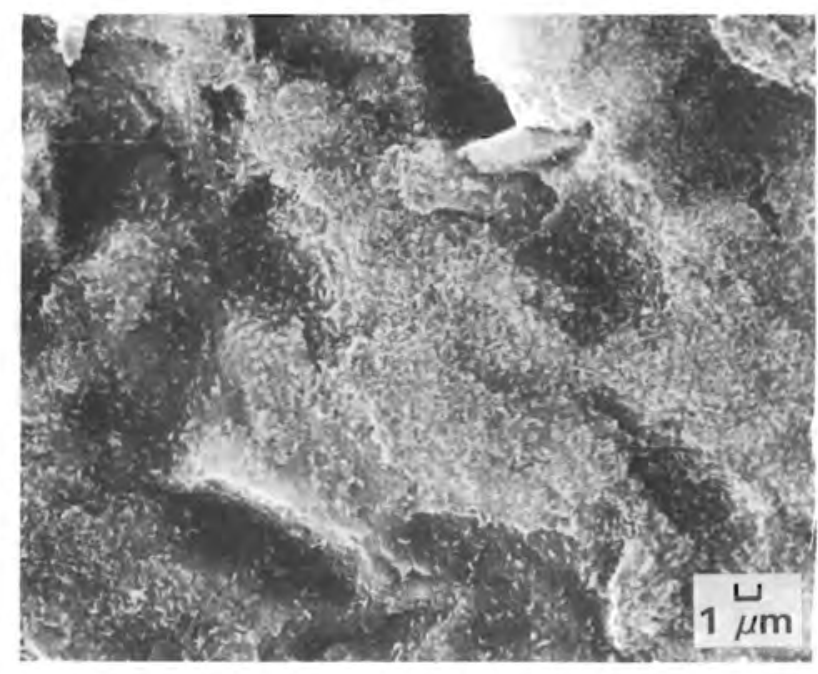

D

FIGURE 29. Scanning Electron Micrographs of Surfaces Before and After 28 Days Leaching. A, Parent Glass BG-50 before leaching. B, Glass Ceramic BGC-50 before leaching. C, BG-50 after leaching. D, BGC-50 after leaching. 


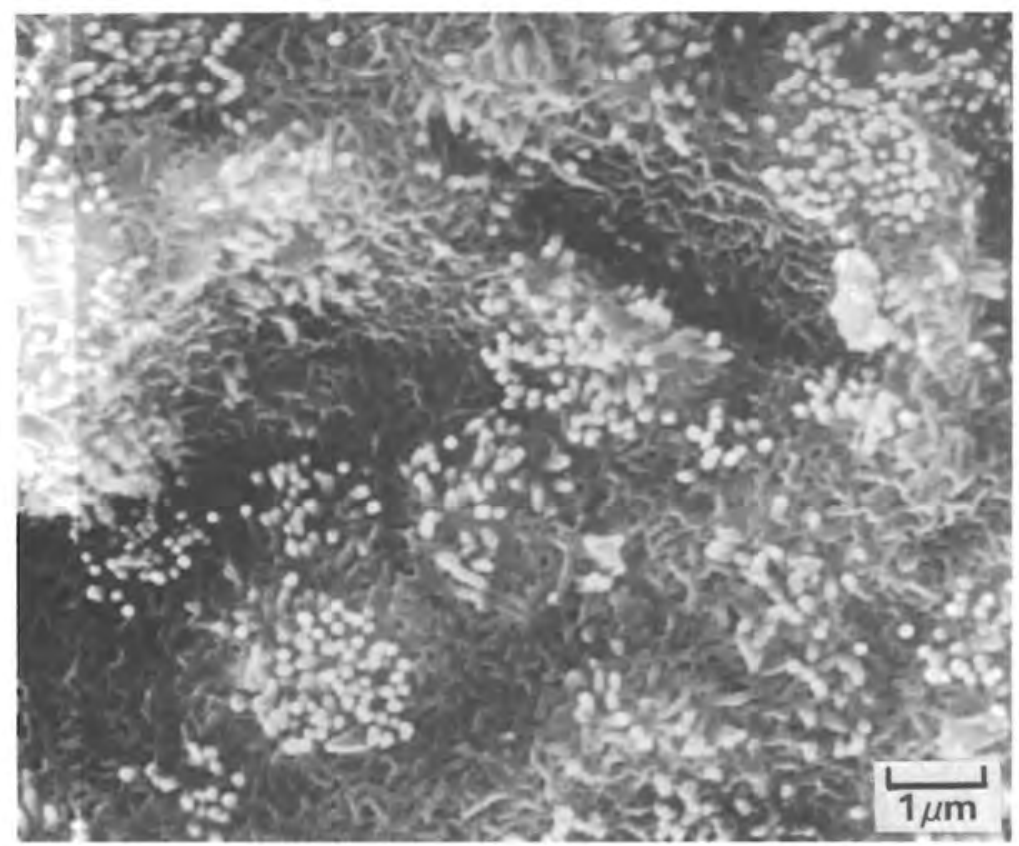

A

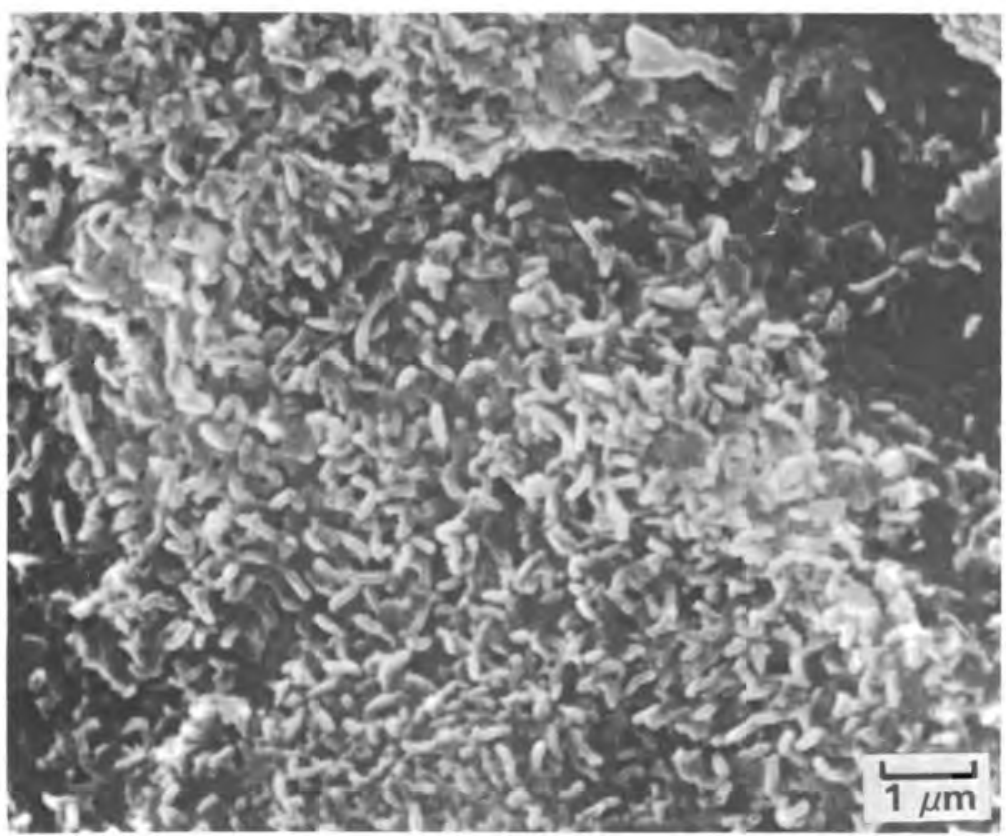

B

FIGURE 30. Scanning Electron Micrographs of 28-Day Leached Surfaces. A, Parent Glass BG-50. B, GTass Ceramic BGC-50. 

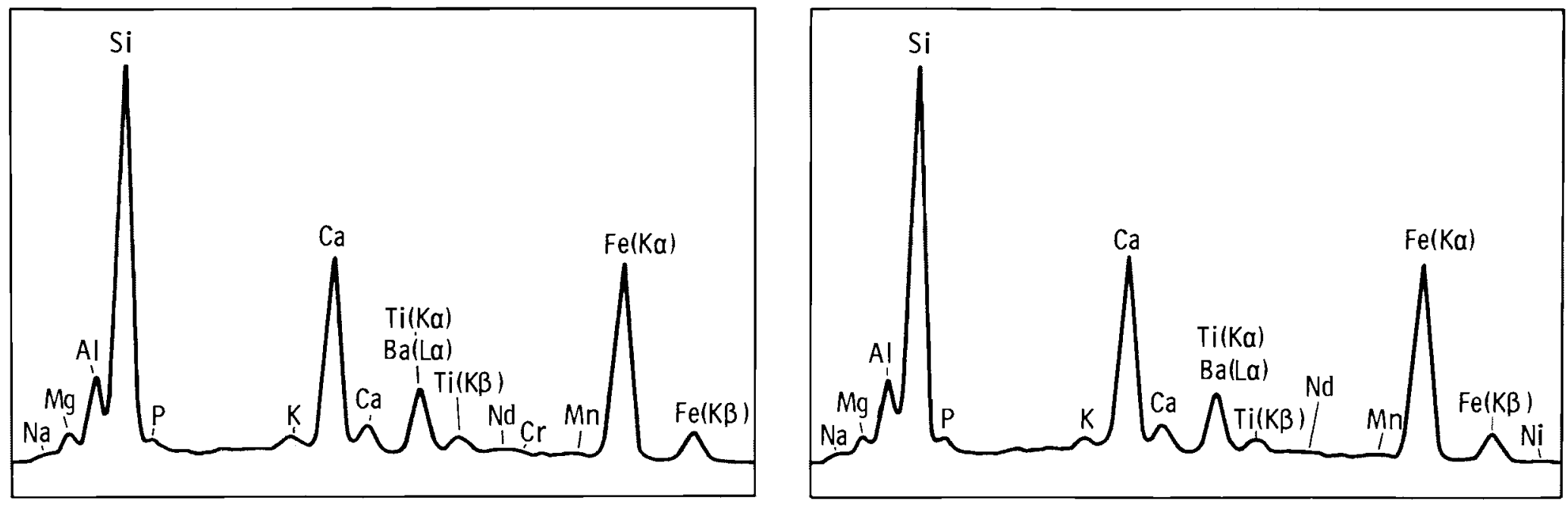

ร)
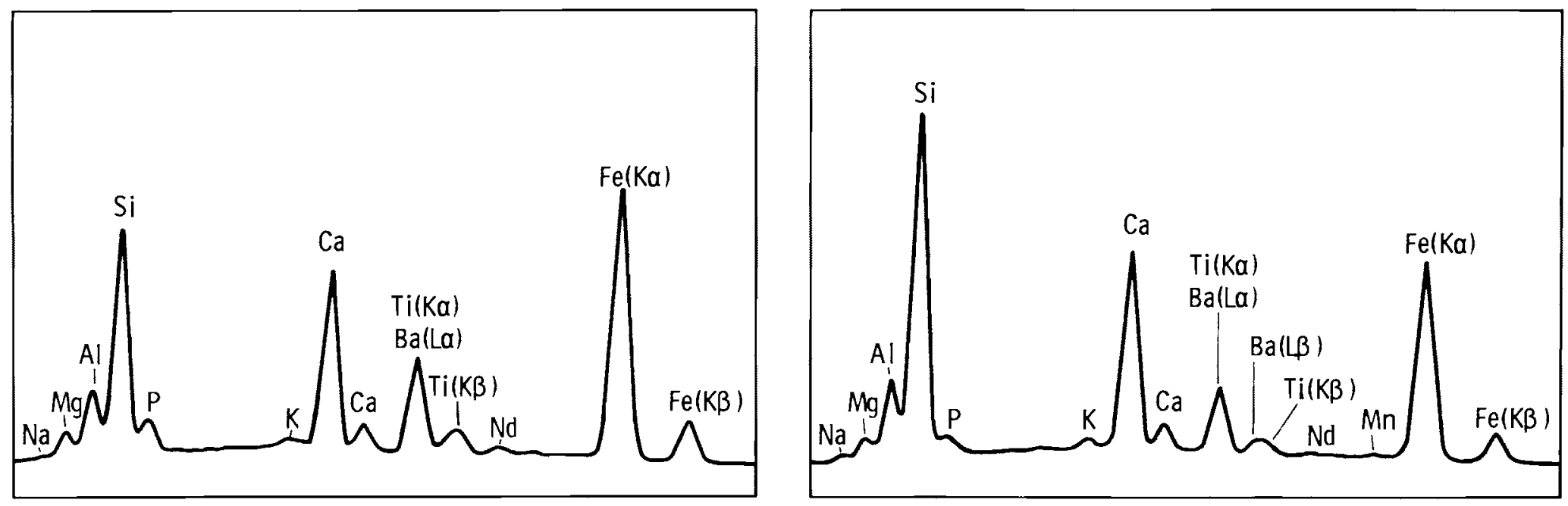

FIGURE 31. Energy Dispersive X-Ray Spectra from $300 \times 300 \mu \mathrm{m}$ Areas on Sample Surfaces Before and After 28-Day Leaching. A, Parent Glass BG-50 before leaching; B, Glass Ceramic $B G C-50$ before leaching; $C$, Parent Glass BG-50 after leaching; $D$, Glass Ceramic $B G C-50$ after leaching. 


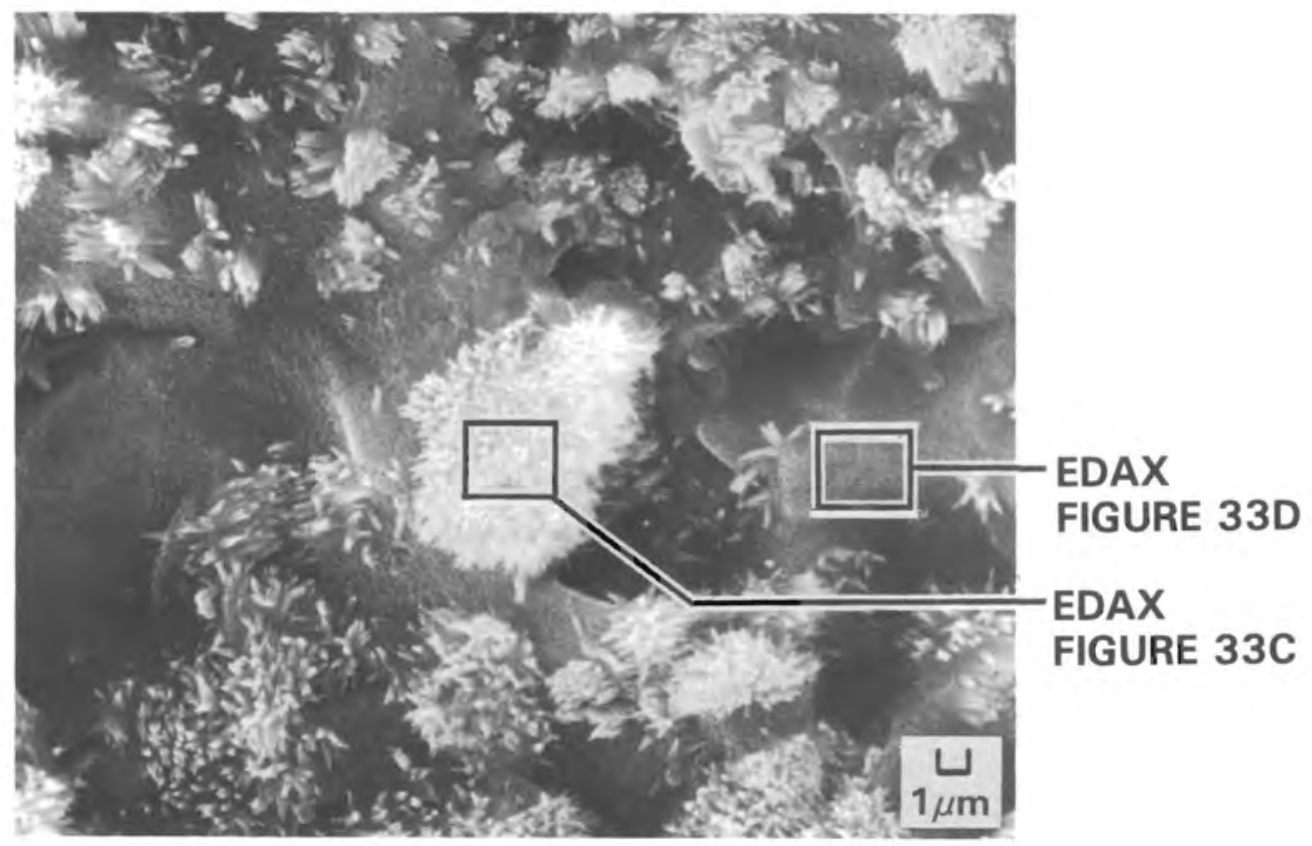

A

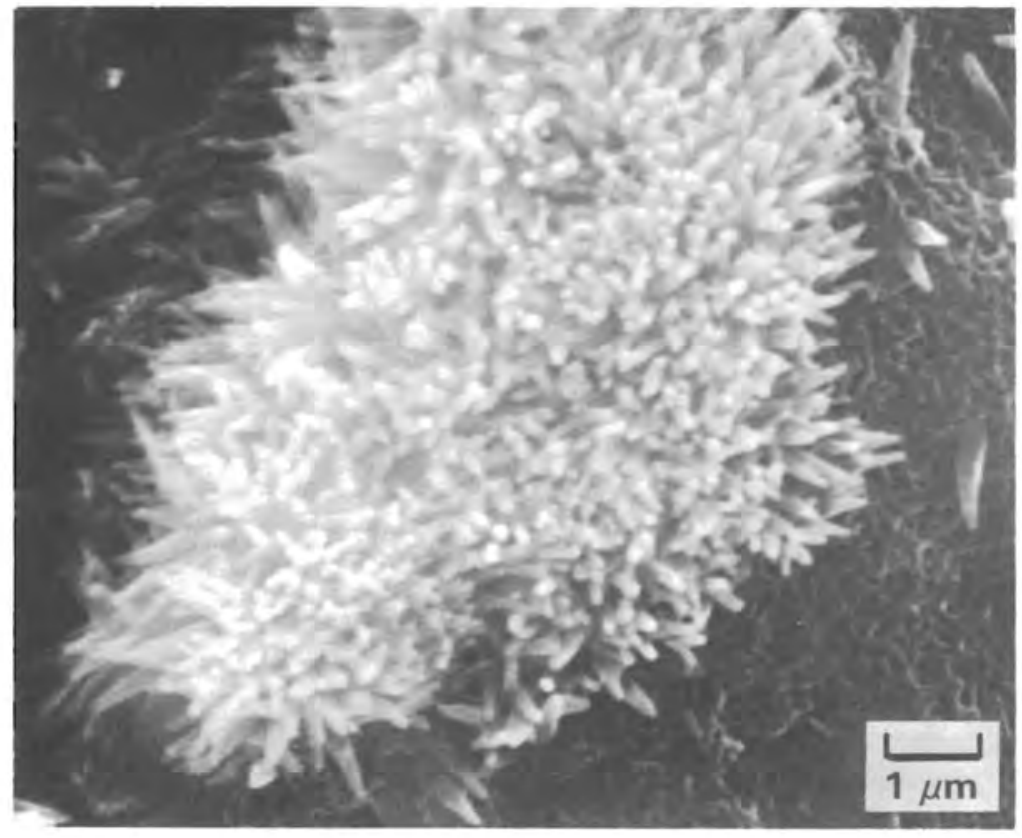

B

FIGURE 32. Scanning Electron Micrographs of Precipitate on Leached Surface of Parent Glass SBG-63 

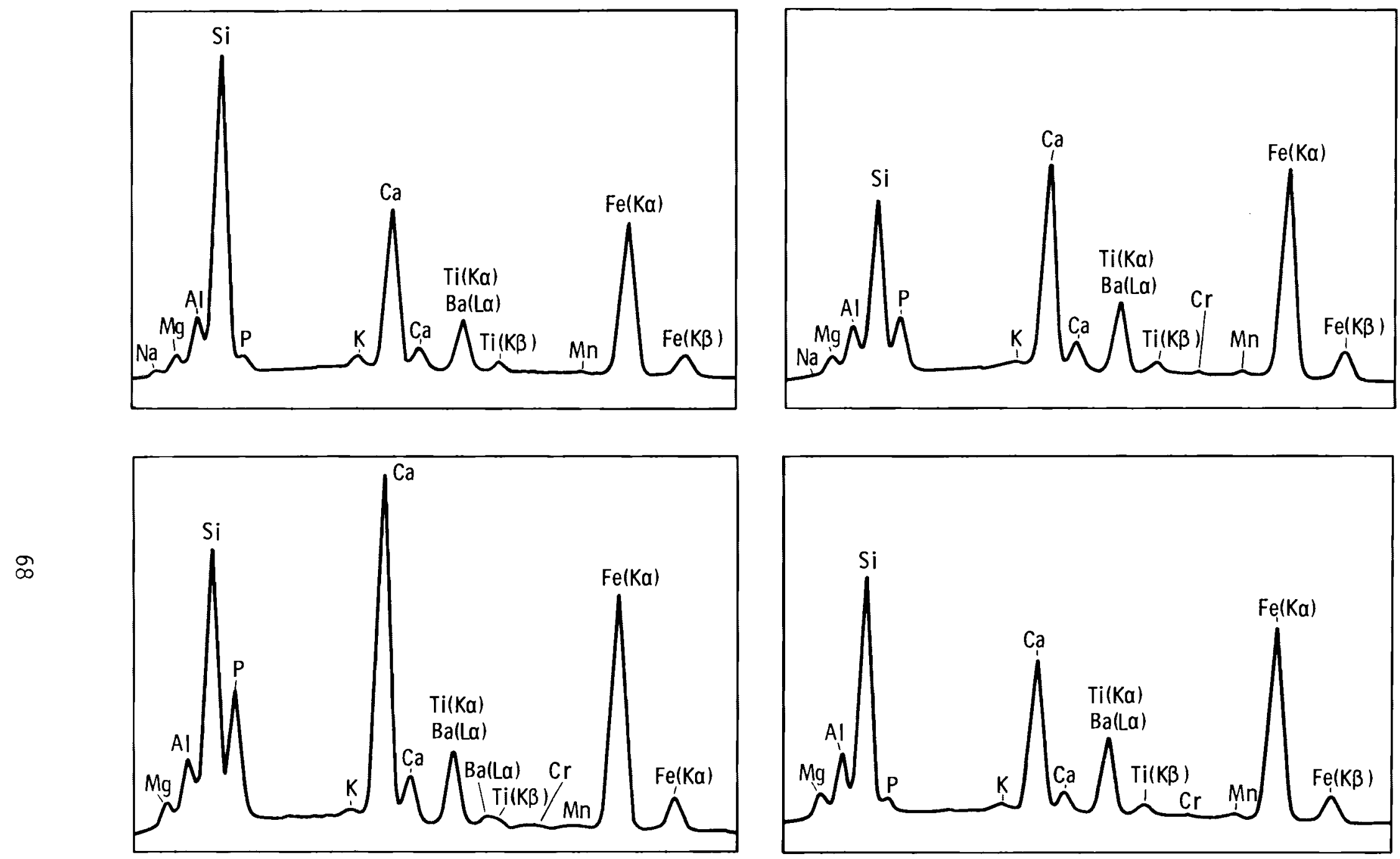

FIGURE 33. Energy Dispersive X-Ray Spectra on Surface of Parent G1ass SBG-63. A, 1arge area scan before leaching; $B$, large area scan after leaching; C, spectrum from precipitate shown in Figure 32A; D, spectrum from between precipitate in Figure $32 A$. 
APPENDIX

SAMPLE PREPARATION AND CHARACTERIZATION PROCEDURES 
APPENDIX - SAMPLE PREPARATION AND CHARACTERIZATION PROCEDURES

$\underline{X-R a y ~ D i f f r a c t i o n}$

Samples were ground to pass 325 mesh in a tungsten carbide (WC) laboratory disk mill. Contamination by WC was negligible since the only unequivocal major WC peak $\left(48.4^{\circ} 2 \theta\right)$ is barely discernible in the worst case. Each powder specimen was loaded into a sample holder in a manner demonstrated to avoid preferred orientation effects (Cullity, 1956). Diffractograms were generated using a General Electric Diano XRO system with CuKa radiation and Ni filter.

\section{Scanning Electron Microscopy}

Samples for SEM (fracture surfaces, leached surfaces, or mechanically polished cross sections) were coated with carbon by vacuum deposition.

The SEM used was a JSM-U3 having 100 to $150 \AA$ resolution. The electron microprobe analyzer used for EDAX traces was a Tracor-Northern 880 with a $\mathrm{Si}(\mathrm{Li})$ Kevex detector.

\section{Scanning Transmission Electron Microscopy}

Because of the relatively recent introduction of the STEM technique to characterization of complex ceramics, this section on the STEM procedure is somewhat more detailed than those for the longer established XRD and SEM procedures.

\section{Specimen Preparation}

Specimens of the four basalt glass ceramics were prepared for transmission/scanning transmission electron microscopy (TEM/STEM) by the following procedures: polished sections about $1 \mathrm{~mm}$ thick were cemented to glass microscope slides using Buehler thermoplastic cement, and ground to about $30 \mu \mathrm{m}$ in thickness. The ground sections were lapped with $1 \mu \mathrm{m}$ diamond paste, and the thermoplastic resin was removed by soaking in acetone and methylene chloride. Slotted TEM beryllium grids $3 \mathrm{~mm}$ in diameter were then 
glued to both sides of the thin sections using Eastman 910 cement. This procedure was used to facilitate handling of the fragile thin sections. Final specimen thinning was accomplished by argon ion micromilling. The resulting specimens had thin centers with many small perforations. About $3 \mathrm{~nm}$ of carbon was evaporated onto both sides of the specimens to reduce charging during electron microscope examination.

\section{Electron Microscopy}

Electron microscopic examinations were performed at $100 \mathrm{kv}$ in a JEOL model $100 \mathrm{CX}$ TEM/STEM instrument. The microscope was equipped with a high-brightness $\mathrm{LaB}_{6}$ eleç.tron source, an "ultra-thin window" (UTW) energy-dispersive $X$-ray detector, computer-based multichannel $x$-ray analyzer and $\pm 45^{\circ}$ double-tilt $x-y$ specimen goniometer stage. The UTW X-ray detector contained a $0.2 \mu \mathrm{m}$ thick organic/aluminum window in place of the usual $8 \mu \mathrm{m}$ thick beryllium window, and can detect elements as light as carbon (Thomas, 1980). The characterization included conventional transmission electron microscopy, crystal structure identification by selected area electron diffraction of individual crystals and polycrystalline regions, and elemental analysis by energy-dispersive $X$-ray (EDX) microanalysis.

\section{X-Ray Microanalysis}

Energy-dispersive $X$-ray microanalysis in the analytical electron microscope may be used to determine compositions of selected specimen regions $20 \mathrm{~nm}$ $(200 \AA)$ or less in diameter. For analyses, the microscope was operated in the scanning transmission (STEM) mode to provide an intense, focused convergent beam which can be positioned on a specimen feature or region of interest. By selecting suitably thin specimen regions to limit electron beam spreading, the region from which $x$-rays are excited can be kept only slightly larger than the probe diameter. Quantitative $x$-ray analysis is also greatly simplified if the specimens are sufficiently thin that $X$-ray absorption and fluorescence by the specimen are negligible.

In the present work a $10 \mathrm{~nm}$ diameter electron probe was used in the STEM mode for EDX microanalysis. The diameters of the crystals and glass regions which were analyzed ranged from about $50 \mathrm{~nm}$ up to several $\mu \mathrm{m}$. The analyzed 
regions were sufficiently thin (20 to $150 \mathrm{~nm}$ ) that beam spreading did not affect the spatial resolution of the analyses. However, superposition of crystals and glass matrix material along the electron beam path does affect the analyses, particularly for the smaller crystals. The analyses reported here are from regions which are much thinner than the apparent crystal size, so that accidental crystal/matrix superpositions were minimized.

For X-ray analyses, the beryllium grid/specimen sandwiches were mounted in a graphite specimen holder to eliminate spurious $X$-ray signals from the specimen surroundings. The absence of significant spurious $X$-ray signals was also confirmed by checking spectra acquired with the electron beam directed through a hole in the specimen, and also with the beam directed onto a graphite holder. The latter test produces continuum $X$-rays from the graphite which indicate whether secondary fluorescence of internal microscope components by radiation from the specimen is a problem. The specimen is tilted $38^{\circ}$ toward the detector during analysis.

The $X$-ray detector used in this work had a $10 \mathrm{~mm}^{2} \mathrm{Si}(L \mathrm{~L})$ crystal, and was operated with a $30 \mathrm{~mm}$ specimen to detector crystal distance during analysis. Typical $X$-ray count rates were $500 \mathrm{cps}$, and analyses ran 60 to 100 seconds. The count rate was deliberately maintained near $500 \mathrm{cps}$ to prevent $X$-ray peak broadening caused by the lack of appropriate pulse-pileup correction for 0.2 to $1 \mathrm{keV} X$-rays from the UTW detector. In the $100 \mathrm{CX}$ microscope, the EDX detector looks at the specimen through the objective lens gap so that $X$-ray takeoff is at $90^{\circ}$ to the incident electron beam direction. This configuration produces a very low background of continuum $X$-rays (continuum $X-r a y$ emission is peaked in forward scattering directions) and also prevents scattered electrons from reaching the detector. X-ray spectra obtained in this work, as shown in Figure A.1, illustrate the very low X-ray background, absence of detected electrons, and detection of characteristic $X$-rays from oxygen and other light elements.

For quantitative analysis, the integrated intensities above background for all characteristic $X$-ray peaks were found by least-squares fitting of computer-generated standard spectra to the unknown spectra. K-spectra from 0 , 
$\mathrm{Na}, \mathrm{Mg}, \mathrm{Al}, \mathrm{Si}, \mathrm{P}, \mathrm{K}, \mathrm{Ca}, \mathrm{Ti}$ and $\mathrm{Fe}$, and $\mathrm{L}$ spectra from $\mathrm{Ti}$ and $\mathrm{Fe}$ were included in the fits. Trace amounts of $\mathrm{Zn}, \mathrm{Cr}$ and $\mathrm{Mn}$ were noted in some spectra, but were not analyzed. Whenever observed, these elements were just above the detection 1 imit of $0.3 \mathrm{wt} \%$. The integrated intensities $I_{j}$ for each element were converted to concentrations $C_{i}$ using the relationship (Goldstein, 1979):

$$
C_{i}=\frac{k_{i} I_{i}}{\sum_{i} k_{i} I_{i}} \text {. }
$$

This relationship assumes that the "thin-film" approximation of negligible X-ray absorption of fluorescence is valid, and that one characteristic $X$-ray peak is considered for each element present. The $k_{i}{ }^{\prime} s$ or $k$-factors are constants for the experimental system, and can be measured using homogeneous specimens of known composition. K-factors can also be calculated from "first principles" (Goldstein, 1979; and Zaluezec, 1979). However, these calculations involve the effective thicknesses of absorbing layers between specimen and detector, which were not wel1-known. Unfortunately, no suitable standard specimens containing al1 the desired elements were available. The k-factors used in the present work were obtained by comparing analyses from $5 \mu \mathrm{m}$ square "electron-transparent" regions of the $B G C$ specimens with the bulk compositions found by KOH-fusion ICP spectrometry. This is not a very reliable means of calibration because the BGC specimens are of unknown homogeneity, and the "thin" regions may not meet the thin-film criterion for several of the elements present.

On the other hand, the k-factors measured in this way for aluminum and all heavier elements showed good agreement with previously measured values obtained with metal alloy standards (Thomas, 1980). The k-factor for oxygen was obtained by analysis of a $10 \mathrm{~nm}$ thick sputter-deposited mineral standard (albite). The reliability of this method is also uncertain at present. Table A.1 compares analysis results obtained from several $5 \mu \mathrm{m}$ square thin regions of $B G C-50$ and the corresponding bulk ICP analyses. The results obtained in repeated analyses of this type with all four BGC samples were highly reproducible. 
Although oxygen was analyzed by the UTW detector, the analyses reported in this paper as weight percent of metal oxides are calculated from the metal content only, assuming the stoichiometry shown. Oxygen contents calculated in this way were typically 50\% greater by weight than the measured oxygen content. The discrepancy increases with increasing sample thickness, and is attributed to absorption of the oxygen $X$-rays in the specimens. For ten percent absorption of oxygen $X$-rays in $\mathrm{MgO}, \mathrm{SiO}_{2}, \mathrm{Fe}_{3} \mathrm{O}_{4}$ and $\mathrm{TiO}_{2}$, calculated limiting specimen thickness are 54, 39, 28, and $14 \mathrm{~nm}$ respectively (Zaluzec, 1979). Absorption of oxygen $X$-rays by titanium atoms was particularly noticeable from relatively thick FeTiO $x$ hematite crystals found in the BGC samples. For all elements heavier than oxygen and possibly sodium, use of the thin film approximation is justified in this work.

Analyses of sodium and phosphorus also presented problems. Phosphorous appeared to move away from the electron irradiated regions during some analyses; crystals containing phosphorous were visibly evaporated under the electron beam. In addition, the sodium content of glass regions appeared to vary systematically with the thickness of the analyzed region. Very thin regions showed high sodium concentrations, and the apparent sodium concentration fell with increasing specimen thickness. The observations may indicate the presence of sodium-enriched films at the surfaces, possibly due to selective sputtering during ion micromilling. Also, one specimen which was not carbon-coated before anaysis, BGC-35-2, showed anomalously low sodium.

\section{REFERENCES}

Goldstein, J. I. 1979. "Principles of Thin-Film X-Ray Microanalysis," pp. 83-120, in Introduction to Analytical Electron Microscopy, J. J. Hren, J. I. Goldstein and D. C. Joy (Eds.), PTenum Press, New York.

Thomas, L. E. 1980. "Microanalysis of Light Elements with an Ultrathin Window X-Ray Spectrometer," pp. 90-93, Proceedings of Thirty-Eighth Annual EMSA Meeting, G. W. Bailey (Ed.), Calitor's, Baton Rouge.

Zaluzec, N. J. 1979. "Quantitative X-Ray Microanalysis," pp. 121-167, ibid Goldstein 1979.

Zaluzec, N. J. 1981. "Elemental Microanalysis Using Analytical Electron Microscopy," in Proceedings of Symposium on Phase Stability During Irradiation, J. R. Holland, L. K. Manusr and K. I. Potter (Eds.), TMS-AIME. 
TABLE A.1. Comparison of Bulk (ICP) Analyses with EDX Microanalyses of $5 \mu \mathrm{m}$ Square Thin Specimen Regions of BGC-50

Composition, wt \%

\begin{tabular}{|c|c|c|c|c|}
\hline \multirow[b]{2}{*}{ Oxide } & \multicolumn{3}{|c|}{ EDX Analysis } & ICP Analysis \\
\hline & $133(a)$ & $134(a)$ & $135(a)$ & \\
\hline $\mathrm{Fe}_{2} \mathrm{O}_{3}$ & 14.5 & 14.2 & 16.1 & 15.4 \\
\hline $\mathrm{TiO}_{2}$ & 3.9 & 2.9 & 4.3 & 4.2 \\
\hline $\mathrm{CaO}$ & 9.0 & 8.9 & 9.0 & 8.8 \\
\hline $\mathrm{K}_{2} \mathrm{O}$ & 0.5 & 0.7 & 0.7 & Not Analyzed \\
\hline $\mathrm{P}_{2} \mathrm{O}_{5}$ & 1.2 & 1.3 & 1.5 & 2.7 \\
\hline $\mathrm{SiO}_{2}$ & 45.8 & 48.8 & $45 . \ddot{0}$ & 46.1 \\
\hline $\mathrm{Al}_{2} \mathrm{O}_{3}$ & 11.7 & 12.2 & 11.9 & 10.1 \\
\hline $\mathrm{MgO}$ & 6.1 & 6.6 & 6.5 & 5.4 \\
\hline $\mathrm{Na}_{2} \mathrm{O}$ & 7.3 & 4.5 & 4.4 & 5.2 \\
\hline
\end{tabular}

(a) Corresponds to analysis number. 


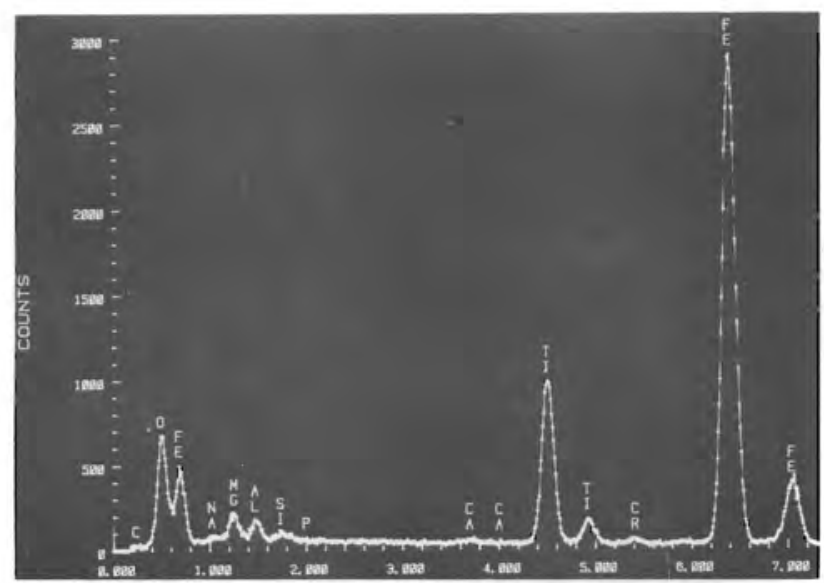

TYPE A:

TITANIFERROUS

HEMATITE

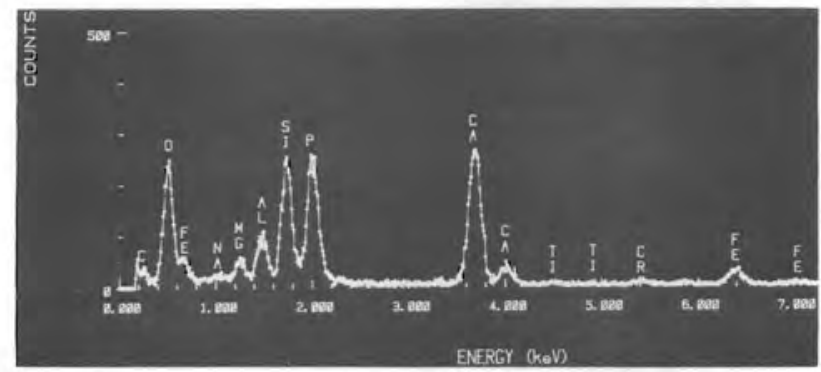

TYPE F:

APATITE

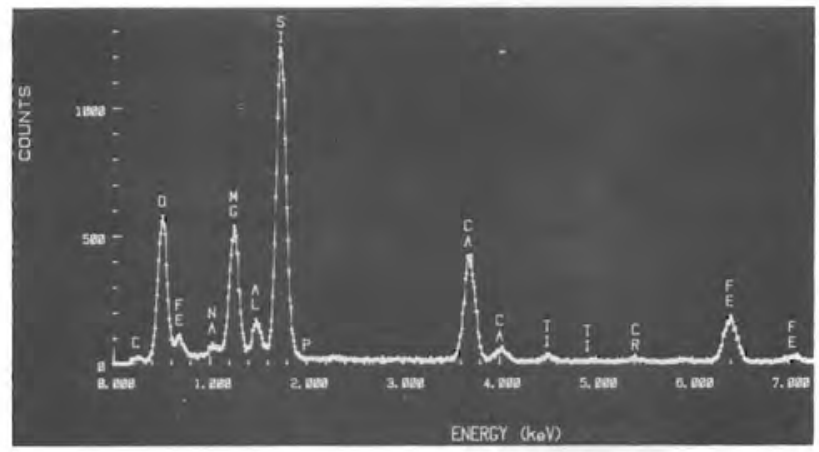

TYPE C:

AUGITE

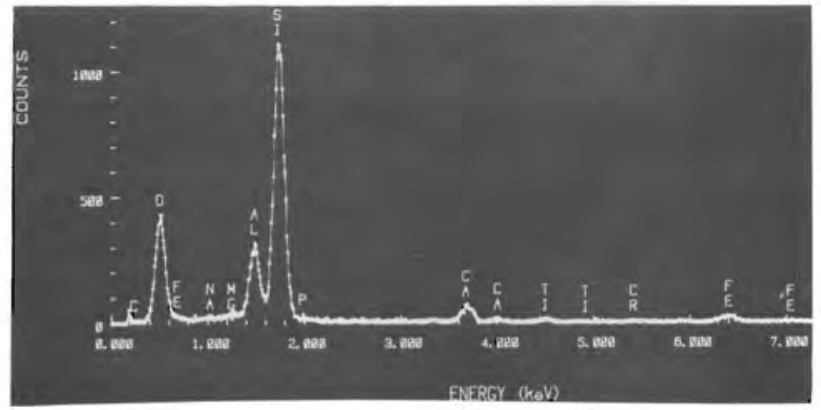

MATRIX:

GLASS

FIGURE A.1. Ultrathin Window EDAX Spectra From Phases in Glass Ceramic BGC-35-2 
.

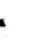




\section{DISTRIBUTION}

No. of

Copies

OFFSITE

27 DOE Technical Information Center

E. L. Albenesius

E. I. duPont de Nemours \& Co. Savannah River Laboratory

Aiken, SC 29801

2 Argonne National Laboratory

9700 South Cass Avenue

Argonne, IL 60439

Attn: J. H. Kittel

M. J. Steindler

2 Battelle Memorial Institute

Office of Nuclear Waste Isolation

505 King Avenue

Columbus, $\mathrm{OH} 43201$

Attn: N. E. Carter

S. Goldsmith

J. 0. B lomeke

Oak Ridge National Laboratory

P. 0. Box $X$

Oak Ridge, TN 37830

J. J. Cohen

Science Applications, Inc.

1811 Santa Rita Road

Suite 104

Pleasanton, CA 94566

J. L. Crandal1

Savannah River Laboratory

Aiken, SC 29801
No. of

Copies

OFFSITE (contd)

R. E. Cunningham

Office of Nuclear Materials

Safety \& Safeguards

Div. of Fuel Cycle \&

Material Safety

Room 562

U.S. Nuclear Regulatory Commission

7915 Eastern Avenue

Silver Spring, MD 20910

2 U.S. Department of Energy

Savannah River Operations Office

P. 0. Box A

Aiken, SC 29801

Attn: E. S. Goldberg

T. B. Hindman

U.S. Department of Energy Oak Ridge Operations Office P. O. Box E

Oak Ridge, TN 37830

3 U.S. Department of Energy

Nuclear Waste Management \&

Fuel Cycle Programs

Office of Nuclear Fuel Cycle

Rt. 270

Germantown, MD 20545

Attn: 0. Gormley

M. Lawrence

W. H. McVey 
No. of

Copies

OFFSITE (cont $d$ )

$5 \quad$ U.S. Department of Energy Office of Terminal Waste

Disposal \& Remedial Action

Nuclear Waste Management \&

Fuel Programs

Rt. 270

Germantown, MD 20545

Attn: W. W. Ballard

F. E. Coffman

H. Feinroth

R. W. Ramsey

J. A. Turi

$5 \quad$ U.S. Department of Energy

Office of Defense Waste

and Byproducts

1000 Independence Ave. S.W.

Washington, D.C. 20585

Attn: A. A. Camacho

J. E. Dieckhoner

G. K. H. Dertel

A. Taboas

V. G. Trice

\section{P. Dickman}

Reynolds Electric Engineering Co.

Mercury, NV 89023

U.S. Environmental Protection Agency

Technological Assessment Division

AW-559

Office of Radiation Programs

Washington, D.C. 20460

5 K. V. Gilbert

Transuranic Waste Systems Office

Rockwell International

Rocky Flats Plant

Golden, C0 80401
No. of

Copies

OFFSITE (contd)

P. G. Hagan

Transuranic Waste Systems Office

Rockwell Internationa 1

Rocky Flats Plant

Golden, CO 80401

J. P. Hamric

DOE Idaho Operations office

550 2nd Street

Idaho Falls, ID 83401

S. G. Harbinson

DOE San Francisco Operations

1333 Broadway

Oakland, CA 94612

L. L. Hench

Dept. of Materials Science

and Engineering

University of Florida

Gainesville, FL 32611

T. B. Hindman, Jr.

Office of Nuclear Waste Management

U.S. Department of Energy

Washington, D.C. 20545

W. F. Holcomb

National Institutes of Health

B 1dg. 21, Radiation Safety Branch

Bethesda, MD 20205

J. J. Jicha

Office of Nuclear Waste Management

Production Operations Division

U.S. Department of Energy

1000 Independence Ave., S.W. Washington, D.C. 20585 
No. of

Copies

OFFSITE (contd)

J. L. Larocca, Chairman

Energy Research and Development Authority

Empire State Plaza

Albany, NY 12223

Lawrence Livermore Laboratory

Reference Library

P. 0. Box 808

Livermore, CA 94550

G. B. Levin

E.G.\&G. Idaho

P. 0. Box 1625

Idaho Falls, ID 83401

Los Alamos National Laboratory

Reference Library

P. 0. Box 1663

Los Alamos, NM 81544

A. L. Lotts

Oak Ridge National Laboratory

P. 0. Box $X$

Oak Ridge, TN 37830

R. Y. Lowrey

U.S. Department of Energy

P. 0. Box 5400

Albuquerque, NM 87115

S. A. Mann

U.S. Department of Energy

Chicago Operations and

Region Office

Argonne, IL 60439

D. J. McGoff

U.S. Department of Energy

Office of Nuclear Waste Management

Research \& Development and

Byproducts Division

1000 Independence Ave. S.W.

Washington, D.C. 20585
No. of

Copies

OFFSITE (cont $d$ )

G. L. Mezga

Oak Ridge National Laboratory

P. 0. Box $X$

Oak Ridge, TN 37830

W. E. Mott

U.S. Department of Energy

Public Safety Division

1000 Independence Ave. S.W.

Washington, D.C. 20585

J. Neff

U.S. Department of Energy

Columbus Program Office

505 King Avenue

Columbus, $\mathrm{OH} 43201$

2 Division of Waste Management

U.S. Nuclear Regulatory Commission

Washington, D.C. 20555

Attn: J. B. Martin

R. Dale Smith

Oak Ridge National Laboratory

Central Research Laboratory

Document Reference Section

Oak Ridge, TN 37830

Office of the Assistant Manager

for Energy Research and Development

U.S. Department of Energy

Oak Ridge Operations Office

P. O. Box E

Oak Ridge, TN 37830

F. K. Pittman

3508 Sagecrest Terrace

Ft. Worth, TX 76109

R. G. Post

College of Engineering

University of Arizona

Tucson, AZ 85721 
No. of

Copies

OFFSITE (contd)

R. Roy

202 Materials Research Laboratory

University Park, PA 16802

Savannah River Laboratory

Reference Library

Aiken, SC 29801

T. Scott

Transuranic Waste Systems

Rockwell International

Rocky Flats Plant

Golden, CO 80401

R. Williams

Electric Power Research Institute 3412 Hillview Avenue

P. 0. Box 10412

Palo Alto, CA 94304

\section{ONSITE}

5 DOE Richland Operations Office

E. A. Bracken

H. E. Ransom

J. J. Schreiber

M. W. Shupe

F. R. Standerfer

UNC Industries

T. E. Dabrowski

2 Rockwell Hanford Operations

J. L. Deichman

K. A. Gasper

6 Westinghouse Hanford Company

A. G. Blasewitz

L. E. Thomas

(5)
No. of

Copies

ONSITE (contd)

57 Pacific Northwest Laboratory

W. F. Bonner

J. B. Brown

D. B. Cear lock

L. A. Chick (5)

T. D. Chikalla

R. L. Dillon

W. A. Glass

W. E. Kennedy, Jr.

M. R. Kreiter

J. M. Latkovich

R. C. Liikala

R. O. Lokken

J. L. MCElroy

J. E. Mendel

J. E. Minor

I. C. Nelson

R. E. Nightingale

A. M. Platt

J. V. Robinson

S. L. Stein

G. L. Tingey

R. P. Turcotte

C. M. Unruh

H. H. Van Tuyl

B. E. Vaughan

E. C. Watson

J. H. Westsik, Jr.

E. J. Wheelwright

Publishing Coordination (2)

Technical Publication (5) 
